\title{
Império dos Mil Anos e a arte do "tempo barroco": a águia bicéfala como emblema da Cristandade?
}

\begin{abstract}
Jaelson Bitran Trindade ${ }^{2}$
RESUMO: $O$ artigo revela que, entre meados do século XVII e meados do XVIII, no meio eclesiástico das ordens religiosas ljesuítas, franciscanos, agostinhos, cistercienses, carmelitas etc.) e do episcopado, houve a adoção progressiva do símbolo imperial, a águia bicéfala, atributo do Império Cristão, do Sacro-Império Romano Germânico. Entretanto, em campo religioso, essa águia imperial do tempo do Barroco aparece despojada de insígnias políticas (espada, cetro, globo), adornando altares, ostensórios, arcos-cruzeiros, fachadas de templos, portas, cúpulas, paredes, púlpitos, lavatórios sacros, esculturas e pinturas da Virgem e do Menino, vestes litúrgicas, etc.; relacionada, portanto, ao culto e aos dogmas da fé católica - nas obras artísticas, muitas vezes, a associação entre a dupla águia e a unidade carneespírito, humano-divino, princípio axial da fé católica, representada pela Virgem-Mãe e o Cristo é indicada de forma direta. A pesquisa tem localizado e identificado numerosos remanescentes da dupla águia em campo religioso em Portugal e Espanha e em suas antigas conquistas e domínios da América, Ásia e África, e também na ltália, sendo que jamais a historiografia relativa ao doloroso parto da Era Moderna no Ocidente se deu conta de tal fenômeno. Simbolizando o poder absoluto, universal, essas obras de teor sacro, tal como o discurso eclesiástico da época, põem à mostra a movimentação ocorrida, no plano religioso, com vistas à afirmação do poder não só espiritual como terreno do Cristo e seu corpo místico, a Igreja, embalada pela ideia de restabelecer a unidade cristã, a "República Cristã", desmantelada pelos conflitos de poder e de fé, bem como da instauração uma Monarquia Universal Apostólica, com ação política e sacerdotal estendida a toda a Humanidade: o Império dos Últimos Dias, Império de Cristo no Mundo Todo, Quinto Império.

PALAVRAS-CHAVE: Arte Sacra. Quinto Império. Monarquia Universal. Milenarismo. Padre Antônio Vieira. Águia Bicéfala
\end{abstract}

ABSTRACT: The article reveals that between the mid-17th century and the mid-18th century, in the ecclesiastical world of the religious orders Uesuits, Franciscans, Carmelites, Cistercians, Augustinian, etc.) and the episcopate, there was the progressive adoption of the imperial

\begin{abstract}
1. Este artigo desenvolve estudo publicado em 2001 Ver Jaelson Bitran Trindade (2001).

2. Historiador do Instituto do Patrimônio Histórico e Artístico Nacional (Iphan), Doutor em História Social pela Faculdade de Filosofia, Letras e Ciências Humanas da Umiversidade de São Paulo. E-mail: $<$ jaelsont@yahoo.com.br>.
\end{abstract}


3. Ver Padre Antônio Sepp, S.J. (1971). Alemão nascido no Tirol, o padre Antônio Sepp, S. J. esteve em missões na Argentina entre 16911733; traduziu para o alemão as obras Maria Rosa Mística e Sermões, do Padre Vieira. symbol, the double-headed eagle, attribute of the Christian Empire, the Germanic Holy Roman Empire emblem. However, in the religious field, this imperial eagle of the Baroque time appears without the political insignia (sword, scepter and the imperial orb), adorning altars, monstrances, trumphal archs, facades of temples, doors, walls, domes, pulpits, sacred washbasins, sculptures and paintings of the Virgin and Child, liturgical robes, etc.; therefore related to the cult and the dogmas of the Catholic faith - in artistic works, the association between the double eagle and the flesh-spirit or human-divine unity, axial principle of the Catholic faith, represented by Virgin-Mother and Christ, is often indicated directly. The research has located and identified numerous remnants of the double eagle emblem in religious field in Portugal and Spain and in their conquests and dominions in America, Asia and Africa, and also in Italy, and the historiography on painful birth of the modern era in the West has never realized this phenomenon. Symbolizing absolute power, universal power, these works with sacred significance, as the ecclesiastical discourse of the time, demonstrate movement occurred in religious plane. With the aim to assert not only spiritual but also temporal power of Christ and his mystical body, the Church was impelled by the idea of restoring the "Republica Christiana" or Christendon - disrupted by conflicts of power and faith - and of introducing a Universal Apostolic Monarchy extended to all mankind: the Empire of the Last Days, the Empire of Christ in the world, the Fifth Empire.

KEYWORDS: Church Art. Fifith Empire. Universal Monarchy. Millenarism. Father Antonio Vieira. Double-headed Eagle.

\begin{abstract}
"No usamos el rosario en el cinturón, sino siempre pendiendo del cuello, para que los salvajes paganos reconozcan que somos cristianos y humildes esclavos de Nuestra Digna Señora. Todos los indios, los hombres como las mujeres, los grandes y los pequeños, llevan el rosario en el cuello del mismo modo, en señal de que no son paganos, sino cristianos." ${ }^{3}$
\end{abstract}

Antonio Sepp, S. J., 1696.

Um símbolo, cujo significado anda esquecido há mais de dois séculos, marcou, nas formas ideológicas e artísticas do tempo do Barroco, o difícil, conturbado e doloroso processo de constituição do "mundo novo" que engendrou, via monarquias absolutas, a passagem para os Estados nacionais hegemônicos modernos: naquele tempo, encontravam-se abertos os caminhos de uma monarquia universal ou de consolidação de Estados autônomos, expressando as contradições e as transformações em curso.

Tal figura é a águia de duas cabeças, a águia bicéfala coroada, que simbolizava a unidade dos poderes espirituais e temporais. Mas atenção! Não é a mesma que servia de símbolo do antigo Império Cristão do Oriente (Bizâncio) nem aquela que, desde a medievalidade Ocidental, servia de galardão do SacroImpério Romano e Germânico, estatuto político maior da Cristandade, entrando 
também nos armoriais da nobreza. Aqui se trata do secular símbolo imperial despojado de alguns acessórios (o globo e a espada) - de uma águia bicéfala que aflora e se multiplica em campo religioso, acentuando significados de caráter teológico, a partir do último terço do século XVII, na Europa e no ultramar ibérico. E esse modo de existência do símbolo - deslocado da representatividade política, do Estado, para o mundo da liturgia e do culto religiosos - é uma novidade.

Na Era Contemporânea, porém, o tempo encarregou-se de retirar tal imagem da vista de todos: o tempo e o pensamento "ilustrado" e sua visão da História e do Estado, dos quais o nosso mundo é tributário ${ }^{4}$. Uma vez desaparecidos os motivos mais amplos que a fizeram aparecer e ganhar mundo, ser celebrada e empolgar adeptos, cessou de ser reproduzida, de maneira geral. Contudo, os poderes e virtudes que ela inspirava continuaram, por longo tempo, a ser representados em produtos do artesanato popular.

Na atualidade a águia bicéfala, como símbolo, sobrevive no adorno de trajes femininos, seja em jóias de peitoral utilizadas em festas em algumas regiões da Espanha (Salamanca e llhas Baleares) ${ }^{5}$, seja nos peitorais de prata (trapelakucha) das mulheres Mapuche ${ }^{6}$, no Chile ou ainda, bordada, na peça de vestimenta cerimonial feminina (vestido de noiva, mortalha, etc.) dos povos indígenas de grande parte da América hispânica, denominada geralmente de huipil.

Também como elemento decorativo pode-se destacar a permanência da águia bicéfala - e elementos associados, como a "árvore da vida" - nas chamadas "colchas de Castelo Branco", Portugal, de linho, com bordados em seda, bastante estimadas como peças de enxoval de noiva, produção têxtil que remonta ao séculoXVII7.

Ainda em termos de sobrevivência mas, neste caso, dentro das instituições religiosas é notável a utilização de águias bicéfalas esculpidas nas quinas dos passos ou andores que levam Jesus Nazareno em procissão nas solenidades maiores da fé católica, especialmente na região da Andaluzia, Espanha $^{8}$. Esse emblema também pode ser visto no arremate das varas de prata dos mandatários de confrarias ou irmandades, que seguem a procissão.

Este estudo trata dessa águia bicéfala esquecida, ou melhor, "encoberta" até agora. A que permaneceu na história, visível, é a outra, que chegou até nossos dias vinculada a impérios como o austro-húngaro (sucessor do Sacro Império Romano) e o russo. Assim, no caso do mundo de tradição católica ocidental, no âmbito religioso, toda representação imagética da águia bicéfala engendrada na Era Moderna tem sido lançada - nos textos informativos e historiográficos - à conta do emblema dos Habsburgo

A última grande aparição da águia bicéfala nas representações artísticas, como símbolo de um império cristão terreno, deu-se no limiar da Era Moderna, na vigência de Carlos V como Imperador do Sacro Império Romano e Rei de Espanha (1519-1556), tamanha era a extensão de seus domínios territoriais. Herdeira do multissecular Sacro Império Romano Germânico, a Casa Imperial alemã era a detentora do emblema que a colocava como guardiã da Igreja Católica. O desenvolvimento alcançado pelas artes plásticas e pela imprensa, nesse período, encarregou-se de sua ampla disseminação. Mas esse
4. O projeto de "monarquia universal católica", bem como seu viés de teor apostólico e a ideologia e o debate relacionado a essa questão, não feneceram com a quebra do grandioso Império de Car$\operatorname{los} \mathrm{V}$ (1555), muito pelo contrário, a expansão européia continental e ultramarina propiciou um recrudescimento da questão. O seu ponto alto pode ser localizado mais ou menos no final do século XVI, limiar do XVII, época marcada pelas obras do frade dominicano Tommaso Campanella (15681639), principalmente $D e$ monarchia bispanica discursus (1601) e De Monarchia Messiae (1605), e teve seu ponto de inflexão por volta de 1730 , marcado por discursos como o de Montesquieu (1689-1755), em especial suas Réflexions sur la monarchie universelle en Europe, editadas em 1734.

5. Como é o caso do conjunto de adornos de prata e coral, ou de ouro, denominado "emprendada" que as mulheres usam em Ibiza, Espanha, para identificar os momentos da vida. O conjunto inicial é quando, ainda menina, a mulher faz a primeira comunhão; cf. Ayuntamient de Santa Eulària des Riu.

6. Ver Oreste Plath (19551957).

7. Ver Clara Vaz Pinto e João Pedro Monteiro (1993).

8. A título de exemplo, em Sevilha, entre outras, as Irmandades de Nuestra Señora del Rosario Santisimo y Cristo de las Siete Palabras, a dos Nazarenos e a de Jesús del Gran Poder, que têm o passo entalhado mais antigo (ca 1688-1692). Em Marchena, Cadiz e Jerez de la Frontera também encontramos irmandades que levam as águias bicéfalas no Passo do Senhor. 
era o emblema de um poder terrenal: a águia bicéfala estava contida num escudo heráldico e, no centro, levava outro escudo heráldico.

No século XX, historiadores da arte depararam, acidentalmente, com algumas situações que escapavam à compreensão desse símbolo como dos Habsburgos imperadores: o espaço geográfico onde se encontrava; o tipo de obra e a aparente época de sua feitura - meados do século XVII até as primeiras décadas do século XVIII - causavam dúvidas. Isso ocorreu especialmente em relação ao mundo português, cuja monarquia e seus símbolos eram distintos dos de Espanha. E ocorreu nos primeiros tempos em que historiadores de arte notavam o barroco e suas grandes obras em Portugal e no Brasil, ou seja, no decorrer da década de 1940. Pouquíssimas linhas, porém, registram a presença do símbolo e alguma conjetura a seu respeito - um panorama que praticamente não se alterou nestes últimos 60 e tantos anos.

Nos livros de história da arte no Brasil, ficaram registradas as imagens de apenas duas ocorrências, ambas nas proximidades da capital do Estado de São Paulo, em templos datados de fins do século XVII a início do XVIII: a igreja da residência jesuítica e aldeia de missão, de Embu Mirim (Embu), sob a invocação de Nossa Senhora do Rosário; e a pequena e bela capela rural do Sítio de Boiprossugava, dedicada a Santo Antônio de Lisboa (São Roque). Ambos os templos tiveram suas obras iniciadas no decorrer da década de 1680 e princípios da de 1690. São hoje protegidos por lei federal, classificados como Monumentos Nacionais.

No Embu, cada um dos dois altares colaterais ao arco-cruzeiro tem uma águia bicéfala como arremate. E, na capelinha de Santo Antônio, em São Roque, a figura está estampada na face do púlpito.

Questões de decoração artística e representação simbólica, como essas, não poderiam ser resolvidas, evidentemente, sem buscar suas fontes, suas conexões na arte portuguesa, na cultura artística e religiosa portuguesa do século $\mathrm{XVII}$, mas neste caso, como em muitos outros temas no campo da cultura lusobrasileira, sequer isso fora intentado.

Além do que, a figura da águia bicéfala coroada é inequivocamente - do ponto de vista iconográfico - um símbolo de poder, e poder imperial. Tal representação como dito antes, simbolizava o estatuto político de Império, do Sacro-Império Romano Germânico, que durante todo o século XVII ainda o exibia com grandiosidade. Indiscutivelmente, não era usual a presença de símbolos do poder político nos objetos nos quais eles estavam estampados aqui no Brasil púlpitos, altares -, nem esse símbolo de domínio político tinha alguma coisa a ver com o Brasil e Portugal da época em que ele assomou com magna presença nos equipamentos litúrgicos e de culto.

Em Portugal e Espanha, onde estive por duas ocasiões mais dilatadas, fiz sondagens no sentido de encontrar a matriz ideológica, as pautas teológicas e políticas às quais aquela representação devia necessariamente se ater; recolhi indícios e evidências. Logo na primeira viagem lo motivo da estadia não era a pesquisa sobre o tema), tive acesso a uma pequena gravura (comentada mais adiante), mostrando nitidamente a representação da águia bicéfala com 
significado divino, celestial, associada ao Sol e à Lua, ao Cristo e à Virgem Mãe - que, desde o "empíreo", têm a seus pés o Imperador e o Papa, a Cristandade e a "Igreja de Pedro", e a decisão da vitória contra forças opostas a essa "Humanidade" cristã. A águia, no meio do céu, pousada na meia-lua; e, sobre suas duas cabeças, o Sol com o monograma AM (Ave Maria) - o Cristo e a Virgem, Sol e Lua.

A literatura sacra seiscentista, portuguesa e espanhola consultada desde as primeiras pesquisas acabou por apresentar as figuras máximas do Cristo e da Virgem Mãe como Imperador (rex regum, dominus dominantium) e Imperatriz do Orbe, com suprema potestade sobre todos os imperadores, reis e príncipes cristãos do mundo e suas jurisdições?

Em relação a esse tema da águia bicéfala seiscentista ${ }^{10}$, barroca, o avanço dos trabalhos permitiu as seguintes constatações:

- Tal símbolo da águia bicéfala - que por toda a parte do mundo católico mais fortemente romanizado durante a segunda metade do século XVII e as duas primeiras décadas do XVIII (c. 1660-1730) aparece com frequência como um motivo realçado nos objetos artísticos, na ornamentação arquitetônica e nas artes decorativas do "tempo barroco" - não é o símbolo do Sacro Império Romano Germânico, nem o da dinastia dos Habsburgos, nem o da Ordem de Santo Agostinho' ${ }^{1}$, pois está desacompanhado dos elementos heráldicos e das insígnias que compõem as suas respectivas armas (mas coexiste com os dois outros e diferencia-se deles). É uma reapropriação do símbolo de status imperial político, a bem e a serviço de um projeto imperial eclesiástico. É o emblema da Cristandade, enquanto união e unidade na qual a fé verdadeira está afirmada; enquanto projeto imperial, representa o poder do Cristo e de sua lgreja, a que tudo deve se submeter. Os Mistérios da Fé, ou o equivalente Rosário da Virgem, dão suporte a tal emblema.

- Pela primeira vez, no Ocidente cristão, o antigo símbolo da águia bicéfala destaca-se de seus limites institucionais consagrados, translada-se para o campo religioso e universaliza-se, seja lavrado em pedra, madeira, metais, couro; tecido em fios de seda, ouro, prata, lã e algodão; pintado em azulejo, louça e tecido, e estampado em papel. Além disso, no púlpito das igrejas, nos textos doutrinários, fala-se das ideias que ele contém.

- Contemporaneamente, a águia imperial aparece associada a diferentes congregações religiosas: agostinhos, jesuítas, franciscanos, dominicanos, carmelitas, beneditinos, cistercienses etc. E em diferentes partes do mundo que estiveram sob domínio da Monarquia Católica, da Monarquia Portuguesa ou em territórios ligados diretamente ao Pontífice. Chama a atenção o fato de tal iconografia não aparecer nos templos das terras do Sacro Império Alemão - justamente aquele que tem uso político da águia bicéfala como símbolo de império.
9. Ver Jacques Le Goff e Jean -Claude Schmitt (2003, p. 222-223); Juan Machado de Chaves (1647, p. 269 e ss.).; e Padre Antonio Quintanadueñas, S. J. (1643, p. 113117).

10. Com apoio da Fundación Carolina, do Ministerio de Asuntos Estranjeros, da Espanha, iniciei por aquele país (abril-junho de 2005) os trabalhos regulares de campo, que têm por objeto analisador a águia bicéfala em campo religioso. Em estudo recente (2003), verifiquei a associação entre os aspectos messiânicos, apocalípticos, desse projeto imperial eclesiástico, que se apossa do velho símbolo do império cristão, e a forma que toma em Portugal o retábulo eucarístico do tempo do Barroco. Essas obras de talha, que pela sua originalidade são fenômeno sem paralelo na Europa daquele tempo, recebem hoje a denominação de talha "de Estilo Nacional Português": remetem para a forma do portal das igrejas do Românico europeu (sécs. XII e XIII), metáfora da Porta do Céu. Têm sua existência no período que corresponde basicamente ao da aparição da águia bicéfala em campo religioso, ou seja, do último terço do século XVII até a década de 1720. Cf. Jaelson Bitran Trindade (2004, p. 311-330).

11. Menos ainda tem a ver com o emblema do Império Bizantino, também uma águia bicéfala. Constantino XI Paleólogo, o último imperador bizantino, caiu juntamente com aquele Império Cristão Oriental em 1453. Com o símbolo do império cristão oriental tem relação a águia que modernamente se encontra em relevo na porta principal da Igreja Ortodoxa Oriental na cidade de São Paulo, Brasil. 
12. No século XVII, são numerosas as obras que identificam a Mãe de Deus com a Igreja. Essa conotação vem dos primórdios da Cristandade. O historiador André Grabar, em seu importante estudo sobre a iconografia cristã na Antiguidade e Idade Média, nos ensina que a Virgem com os braços em posição de prece e o Menino em seu colo, que aparece, em afresco, já em uma catacumba de Roma, "é ao mesmo tempo ela mesma e o símbolo da Igreja sobre a terra, dupla significação que reveste também as imagens dos séculos V e VI das âmbulas de Jerusalém"; cf. André Grabar (1985, p. 79).

13. Destaco alguns títulos: David Armitage (1998; 2000); John M. Headley (1997); Paul Kléber Monod. (1999); Bridget Orr (2001); Anthony Padgen $(1990 ; 1998)$; Steven Pincus (1992; 2000; 2008).

14. Cf. Alexandre Haran (2000, p. 355)
Na França, no poderoso e Cristianíssimo Reino de França, onde os símbolos mais emblemáticos eram a flor-de-lis (pureza) e a ampola com o sangue de Cristo lque teria sido dada aos fundadores do Império Cristão dos Francos por intervenção divina), rareiam águias bicéfalas nos templos e em seus equipamentos de culto.

- A disseminação da águia imperial ou águia bicéfala coincide com o recrudescimento de projetos de monarquia universal cristã, no jogo de força entre as potencias católicas européias, em que messianismo e dinastia estão conjugados, situação que a historiografia recente vem mostrando nos últimos anos não só em relação à Espanha, mas também em relação à França.

- A profusão de textos ditos espirituais (tratados ou sermões), especialmente no século XVII, realçando o poder superior de Cristo e da Virgem, esta, tomada como a própria Igreja ${ }^{12}$, passa a frisar o domínio, o poder que as divinas figuras têm não apenas sobre os Céus e os Anjos, sobre o Universo, mas também sobre os homens, sobre o Orbe, sobre reis, imperadores, repúblicas.

- Por fim, o fato de a lgreja colocar-se como o "Reino de Cristo", como uma Monarquia Universal diretamente implicada na solução universal do poder, em que, para além do apoio e defesa, teria a concordância do poder temporal, tendo em vista o objetivo de instaurar o esperado Reinado dos Últimos Dias ou Reino dos Mil Anos.

Em relação a tudo o que vai ser exposto, impõem-se breves considerações, principalmente no que se refere ao eixo da questão: a Monarquia Universal do Cristo ou Império Universal.

A historiografia mais recente tem revelado que, no século XVII, ocorre um recrudescimento do messianismo político, visando a uma monarquia universal. Desde meados desse século, diante de uma Cristandade esfacelada em termos econômicos, sociais, políticos e religiosos, até se revigora essa pretensão imperial de algumas potências católicas do Ocidente.

A historiografia de língua inglesa é a que tem abordado com mais vigor tal questão, não só do ponto de vista interno, com ênfase nos "Homens da Quinta Monarquia" e a Revolução Gloriosa, comandada por Cromwell, como também sob o aspecto político (ou, mais propriamente, geopolíitico) da questão, nos enfrentamentos, em termos europeus e ultramarinos, com o poder das monarquias francesa e espanhola ${ }^{13}$.

Sobre o tema do messianismo políitico, no que se refere à França, é caso quase isolado o estudo monográfico de Alexandre Haran, publicado em 2000, em que examina o arsenal ideológico formado principalmente no século XVII para legitimar as pretensões dos reis Luís XIII e Luís XIV de exercer um domínio "sobre o conjunto da cristandade e do universo" 14 . O tema comparece em outras obras - como, por exemplo, a recente biografia de Vauban (1633-1707), escrita por Luc Mary, ou o estudo de Jean-Frédéric Schaub sobre "A França espanhola", 
e, também, a obra coletiva L'empire avant l'empire, dirigida por Gérard Loubinoux -, mas sempre com brevidade ${ }^{15}$.

De qualquer forma, o messianismo político e político-teológico, os significados escatológicos que perpassam a história política e social, tanto da França dos Bourbons como da Espanha dos Áustrias le, depois, também dos Bourbons), ainda não é um objeto de estudo delineado por parte da historiografia. Em relação a Portugal, ao "império luso", ainda carece investigar as práticas e idéias quinto-imperiais na sociedade como um todo, uma vez que os estudos continuam focados no discurso e nas idéias do padre Antônio Vieira (1608-1697) e no tema do sebastianismo, que impregna a história desta nação.

No período aqui tratado, sobre a questão mais específica dos debates e do conceito de monarquia universal, dois estudiosos sobressaem-se na atualidade. A maior referência é o livro Monarchia universalis: storia di un concetto cardine della politica europea, de Franz Bosbach, da Universidade de DuisburgEssen, Alemanha, obra que faz a discussão histórica, com o viés jurídico e filosófico, sobre o conceito de monarquia universal e sua função política na época moderna. É a tese de livre-docência de Bosbach, defendida na Universidade de Bonn, em 1986, publicada em 1988. Só dez anos depois foi editada em língua estrangeira (italiano) ${ }^{16}$.

Bosbach identifica nos inícios da época moderna processos que desembocam num certo renascimento das opções e desígnios imperiais. E, o que é importante, seus estudos levam à conclusão de que o conceito de monarquía universal não serviu "de desenho constitutivo de uma autoridade superior mas, muito pragmaticamente, funcionava como subsídio explicativo de procesos dinámicos da política inter-Estados. [...] foi um conceito cardeal e justificação realista da política inter-Estados européia da época moderna" ${ }^{\prime 17}$. Alguns anos mais tarde, o historiador Peer Schmidt, seu conterrâneo, em estudo eminentemente historiográfico, mostra discordâncias em relação a Bosbach, vendo, ao contrário deste, uma dissociação entre a monarchia universalis tradicional e a nova concepção de imperium (recuperada na monarquía de Carlos V), que se justapõe e rivaliza com o antigo conteúdo desse conceito ${ }^{18}$. Suas idéias, publicadas em artigos traduzidos para o espanhol ${ }^{19}$, só foram desenvolvidas em livro publicado na Alemanha, em 2001, não traduzido para outros idiomas ${ }^{20}$.

De modo geral, nas sociedades de feição corporativa, o político e o religioso conjugavam-se no Estado, mas os fins últimos eram religiosos, espirituais. Assim sendo, o estabelecimento de uma monarquia universal estava relacionado à implantação de uma ldade de Ouro da humanidade, na qual um só pastor, numa unidade Rei-Papa, passaria a reinar sobre a terra.

A entidade mais universal continuava sendo a Igreja Católica. A questão é: como poderia a lgreja, essa forma religiosa de Estado, universal, não agir politica e diplomaticamente - visando a seus fins últimos - nesse processo de quebras, de reconstrução da Republica Christiana numa escala nunca antes vista, ou seja, nas "quatro partes do mundo"?!

Essa profusão, em escala planetária, de águias bicéfalas ou imperiais,
15. Ver Luc Mary (2007); Jean-Frédéric Schaub (2004); e Gérard Loubinoux (2004)

16. Ver Franz Bosbach (1998).

17. Idem, p. 153-154.

18. Cf. Peer Schmidt (2000, p. 71).

19. Ver Peer Schmidt (1998).

20. Ver Peer Schmidt (2001). 
21. Cf. Padre Manoel dos Reis (1717, p. 607). O Padre Manuel dos Reis ingressou na Companhia em 1652. Lente de Filosofia em Coimbra, considerado um dos maiores pregadores da Companhia na época, morreu em 1699 , no Colégio de Braga onde era reitor. É um homem do século XVII, um orador da época de Vieira, que o ouvia com gosto, conforma se atesta no Prólogo do livro, mas a impressão de suas prédicas data de 1717 .

22. Ver frei Salvador Maella (1658).

23. Ver Frei Antonio de Cabrera (1708).

24. Cf. Diego Saavedra Fajardo (1646, p. 509-514).

25. Ver Giovanni Germano (1674). coincidindo com o recrudescimento dos projetos de monarquia universal operou no sentido de afirmar o poder da Igreja, do Cristo, de seus Mistérios, sua Verdade; e, também, de suporte para agir, refletir e pregar em função de seus fins últimos - o advento do Reino dos Mil Anos. Muito mais do que a historiografia, são essas águias bicéfalas imperiais - mas em campo religioso! - e os textos "espirituais" e políticos de então (sécs. XVII e XVIII) que nos mostram esse recrudescimento das perspectivas imperiais abrangendo "cév e terra".

São principalmente as ordens mendicantes e missionárias, antigas e modernas - mas não só elas -, que vão colocar esse símbolo da águia imperial em seus espaços: agostinhos, franciscanos, dominicanos e jesuítas.

No período de que estamos tratando, podemos ouvir, na voz dessas mesmas ordens religiosas, um discurso que fala na quinta monarquia do mundo (ou, menos usado, quinto império) e seu advento, seja em relação ao monarca espanhol, seja em relação ao monarca português; que fala no poder superior, supremo, do Cristo e da Virgem, não apenas como reis e imperadores do Universo, dos Céus, dos Anjos, mas também do Orbe e da Terra, fazedores, desfazedores, ou protetores, de reis e rainhas, de reinos e repúblicas: "Deus não é o supremo Monarca; não é o Rei, que faz, \& desfaz os reis?", pergunta o teólogo jesuíta padre Manuel dos Reis?21

No último terço do século XVI, indicações dos destinos escatológicomessiânicos do monarca e do reino de Espanha, e dos Áustrias espanhóis (por desígnio da Providência Divina), podem ser lidas em sermões ou em tratados, na letra de um jesuíta notório, como o padre João Nieremberg; ou saídos da pena do dominicano Tommaso Campanella (De monarchia hispanica), no início do XVII; ou na de frei Salvador Maella, um padre trinitário espanhol que em 1658, nas Revelaciones del Santo Profeta Daniel, explicadas de la Ilustre Casa Austriaca, intitula Felipe IV de Felipe V Prospero ${ }^{22}$ ou, ainda, nas páginas da obra do teólogo da Província dos Franciscanos Descalços do Reino de Valença, padre frei Antonio de Cabrera, intitulada Glorias de El Señor D. Felipe Quinto, rey de las Españas, y Emperador del Nuevo Mundo (1708), quando um Bourbon, neto de Luís XIV de França, ascende ao trono de Espanha ${ }^{23}$.

No Século de Ouro da Espanha, a profecia de uma Monarquia Universal sob o rei de Espanha pode ser lida nos grandes literatos da época, entre outros, Quevedo, Calderón de la Barca e Porreño Mora. E o conhecido escritor e diplomata D. Diogo de Saavedra Fajardo, "Del Consejo de su Magestad en El Supremo de las Índias, y seu Plenipotenciário para La paz universal", publica em 1646 o seu livro Corona gótica, castelhana y austríaca: politicamente ilustrada, onde se lê que o rei da Espanha será o Rei dos Últimos Dias ${ }^{24}$.

Também sobre a Monarquia Universal da Espanha, é o pouco conhecido tratado Li trionfi della Chiesa e La sperata universale monarchia, publicado pelo padre Germano Giovanni, em 1674, na Itália, com quase 900 páginas!25 $\bigcirc$ monge e teólogo cisterciense faz uma apologia (e defende) ao direito de Carlos II, de Espanha, a essa monarquia desejada e agraciada pelos céus para ter à testa "a Grande Casa Austríaca" - tendo como base uma profecia, a respeito dos papas, de São Malaquias (morto em 1148 ). 
$\bigcirc$ fato é que o messianismo político impera tanto na Espanha como na França, como é o caso na obra de escritores e teólogos intérpretes da Monarquia Cristianíssima, como Postel, Aubéry e Audigier, sem esquecer Tommaso Capanella que, depois de sua prisão, desvia da Monarquia Católica e bandeia para o lado da França de Luís XIII, dedicando ao Bourbon a obra De Monarchia Messiae (1605).

Já a obra do padre Vieira difere da maioria dos tratados políticomessiânicos. A sua doutrina sobre a ldade de Ouro do mundo e da Paz Universal é, em sua solução, mais apostólica do que política, além de estar bem mais de acordo com a dimensão eclesial dos fins últimos da humanidade e com o papel da "Milícia de Cristo" e sua ação nos mundos "não-cristãos".

Para Portugal, para a "vivência imperial" do reino, sabemos que a obra do padre Antônio Vieira é a mais acabada sobre o tema do Império, mas são muitos os textos de jesuítas, agostinhos, franciscanos, carmelitas, beneditinos, cistercienses e teatinos que falam no Império de Cristo na Terra, sempre associados a dois aspectos que se completam: as conquistas em terras de d'além-mar e o "Milagre de Ourique", quando Cristo teria prometido a D. Afonso Henriques, o rei-fundador, o seu império na terra.

Entre o final da década de 1630 e a década de 1650, há uma grande conjunção de escritos nesse sentido, associados à luta pela restauração da monarquia portuguesa, livrando-a do domínio de Espanha. Nesse período le depois dele), Vieira pontifica, com sua obra contínua, que adentra o século XVIII.

Enquanto esteve na Europa - e desde o Brasil, também -, Vieira efetivamente sempre comunicou as suas ideias, que persistem em cartas e em cópias de seus escritos. Conforme ele declara, discutiu as suas ideias com "várias pessoas das mais doutas de sua Religião, Portugueses, Espanhóis, Italianos e Franceses". Ele afirma que em Paris, discutindo as suas matérias com o jesuíta Nicolas Caussin (1583-1651), escritor e confessor do rei Luís XIII, o colega considerou que a grandeza e a importância delas mereciam que se fizesse um Concílio "para maior qualificação delas"26.

Dentre os autores de textos político-teológicos no tempo do Barroco, Antônio Vieira foi o que teve mais fama e mais leitores, e o que esteve mais diretamente ligado a um monarca, para negócios internos e internacionais, além de vivenciar diretamente e por muitos anos o teatro da colonização nas cidades e selvas da América, com ação destacada como dirigente e como predicador. A História do Futuro começa a circular em 1719 e a sua biografia, pelo jesuíta André de Barros, sai em 1746. Como complemento ao título, o autor acrescenta a antonomásia de "O grande aclamado no Mundo" ao "Apostólico Padre Antônio Vieira".

$\bigcirc$ que apresento a seguir diz respeito basicamente ao mundo eclesial português e exemplifica como circulavam, entre o clero, essas doutrinas de um Império Apostólico.

Na cidade do Porto, a lgreja de São João Novo, dos padres eremitas descalços de Santo Agostinho, foi consagrada em 1689. Na fachada, está esculpida uma águia bicéfala, e, no interior do templo, outra, monumental, se destaca sobre o arco-cruzeiro. A prédica solene de consagração do templo
26. Cf. Silvano Peloso (2007, p. 53). 
27. Cf. Frei Francisco Vieira (1708, p. 29).

28. Idem, p. 362 e 188.

29. Cf. Frei José de Oliveira (1723, p. 43).

30. Idem, p. 236.

31. Idem, p. 14 e 16

32. Ver Manuel de Gouvêa (1723).

33. Cf. João Carlos Serafim (2002, p. 74). coincidiu com a data de nascimento do príncipe, de nome João, o esperado herdeiro de Pedro II e futuro D. João V. Naquele cenário, o pregador, padre Francisco Vieira, agostinho descalço, disse que, no príncipe recém-nascido, cumprir-se-ia o vaticínio de o rei português tornar-se Imperador do Mundo ${ }^{27}$.

Se encontramos águias bicéfalas em igrejas dos agostinhos portugueses (e geralmente naquelas devotadas a Nossa Senhora da Graça), também encontramos, na escrita de seus padres, sinais das crenças quinto-imperiais, como nos sermões dos padres José de Oliveira e Francisco Vieira, datados do início da década de 1690. Frei Francisco Vieira, doutor em teologia pela Universidade de Coimbra e lente de sua faculdade, lembra que Cristo fundou o Império lusitano como seu Império na terra, sendo esta a "predestinação políitica" do Reino ${ }^{28}$. E Frei José, bispo de Angola, brada pela total extirpação da fé judaica no Reino, para que se cumpra a sempre lembrada promessa de Cristo, feita em Ourique ao rei-fundador D. Afonso Henriques, de vir a "ser Portugal império dilatado, que se estenderá a todo o mundo"29.

Aquele mesmo frade José de Oliveira, num sermão dedicado ao "Gloriozo Mártir São Vicente" (1698), qualifica Portugal como "Reino de Cristo": "que o reino de Cristo não teria fim: e Portugal é o Reino de Cristo, e Império de Cristo" 30 . $\bigcirc$ "Príncipe da Paz", de quem se espera a vinda na Velha Cristandade, é, diz Frei José, o Rei de Portugal. E as asas de águia são "timbre, e brasão do Império"31.

Lisboa ser a Cidade de Deus, cabeça do Reino de Cristo, é uma afirmação de outro agostinho, frei Manuel de Gouvêa, num sermão sobre São Vicente Mártir, pregado em Lisboa e publicado em 1723, com outros sermões ${ }^{32}$.

$\mathrm{Na}$ edição - feita em Veneza, em 1516, pelas mãos de padres agostinhos - de um conjunto de profecias que, acreditava-se, eram de Joaquim de Fiore (Gioacchino da Fiore, c. $1132-1202$ ), estabelece-se pela primeira vez uma associação entre as profecias da Quinta Monarquia e a Ordem de Santo Agostinho, com a afirmação de que o papa angélico seria um eremita agostinho: "Hic angelus ostendit manu legatis seu ambasciatoribus sancte unionis eclesie: religiosum nigra cucula indutum ut sunt Eremitani sancti Augustini" ${ }^{33}$.

Também padres franciscanos portugueses estavam impregnados de fé messiânica, a julgar por textos de seus sermões e crônicas, e pelas obras que apresentam a águia imperial, ainda que não na mesma quantidade que seus irmãos do México deixaram como testemunho. Vez ou outra, o discurso desses padres faz referência ao vaticínio dado por Cristo ao santo fundador da Ordem, de que esta e o próprio permaneceriam de pé até o fim da lgreja na terra.

Um dado importante é a ligação que os franciscanos da Província da Arrábida, Portugal, tiveram com o Palácio-Convento de Mafra que, juntamente com a lgreja da Patriarcal, de Lisboa, começava a criar a face "romana" da monarquia portuguesa. Desde o início, D. João $V$ quis os franciscanos cuidando da baślica que estabeleceu no palácio. Sobre Mafra, o médico, alquímico e hermetista, Anselmo Caetano Castelo Branco escreveu nesses termos: "nova e única Maravilha do Mundo, que ao mundo mostraremos estabelecida em Portugal, edificada em Cristo, sobreedificada em Mafra e sobre o fundamento, que the pôs 
São Paulo, pelo Real, e invicto braço do Sábio e Augusto Apolo Lusitano, e pelas mãos dos Portugueses, para Corte do Quinto Império de Cristo"34.

Já a Companhia de Jesus é a ordem religiosa emblemática da Era Moderna. $\bigcirc$ ideário da Companhia esteve desde sempre perpassado pelas profecias de Joaquim de Fiore, o abade cisterciense calabrês, relativas ao advento da Monarquia de Cristo na Terra, quando um Grande Monarca e um Papa Angélico, Santo, reinariam sobre o mundo todo convertido à "Lei de Cristo", unindo o mundo temporal ao espiritual.

Inácio de Loyola, o fundador da Societas lesu, ao receber na congregação Francisco de Borja, duque de Gandia e Grande de Espanha, ao tempo em que a grande monarquia católica estava unida ao Sacro Império, interessou-se pela interpretação (de um integrante do novo instituto) de que Francisco seria, ao mesmo tempo, futuramente, tal Monarca Universal e Papa Angélico.

Ainda no século XVI, são documentadas manifestações (com viés joaquimita) entre jesuítas portugueses, como é o caso dos padres Sebastião Gonçalves e Brás Viegas ${ }^{35}$. Gonçalves acreditava que os vaticínios de Joaquim de Fiore, de alguns séculos antes, ajustavam-se ao papel da Companhia; aliás, que as profecias interpretadas pelo abade já indicavam, desde aqueles tempos, o nascimento e a grandeza futura da Societas lesu. A sétima idade da lgreja seria obra, sobretudo, da Companhia!

Dom Gaspar de Leão, primeiro arcebispo de Goa, na segunda metade do século XVI, teve sua educação feita entre os jesuítas, em Évora, Portugal, no Colégio do Espírito Santo. Também ele vê, na ação da Companhia - dilatando a fé católica nos empreendimentos portugueses do Oriente -, o indicativo de uma solução universal para a Cristandade, a desembocar numa liga de toda a Europa. Aliás, o dignitário eclesiástico acreditava que Pio IV, na época reinante em Roma, era o prometido Papa Angélico ${ }^{36}$.

Na Espanha, a partir de 1550, circulou um texto, sob viés joaquimita, com interpretações das palavras dos profetas Habacuc e Isaías, para demonstrar que a corporação dos jesuítas era a renovatio mundi. A busca de signos que viessem a apoiar a leitura dos vaticínios e profecias impregnava os clérigos das mais diversas ordens religiosas ${ }^{37}$.

Quase duzentos anos depois do texto profético antes mencionado, o padre Francisco García, um jesuíta espanhol, ao escrever a Vida, virtudes, y milagros de San Ignacio de Loyola fundador de la Compañia, diz-se honrado pelo fato de serem as velhas profecias de Joaquim de Fiore tidas, por "graves doutores", como referências à futura Companhia e seus padres ${ }^{38}$.

Os jesuítas, como franciscanos e agostinhos, exibem o símbolo imperial da lgreja. Além de esculturas em madeira, pedra e bronze, além de finos bordados em seda nas alfaias e vestuários litúrgicos, a águia bicéfala também é estampada em livros produzidos pela Companhia. Num livro editado em 1717 pela Universidade de Évora, Portugal, a partir do Colégio do Espírito Santo (dos jesuítas), aparece, na parte inferior da folha de rosto (Figura 1)39, uma águia bicéfala sem coroa, de cor clara, com as insígnias da Companhia em seu interior;
34. Ver Anselmo Caetano de Abreu Gusmão de Castelo Branco (1733).

35. Eugenio Asensio (1958, p. XXXIII-XXXV).

36. Idem, p. LXXXIV.

37. Cf. Augustin Redondo e Christine Aguilar (2001, p 155).

38. Ver Francisco García (1722).

39. Ver Padre Manuel dos Reis (1717). 
40. Cf. José Simón Diaz (1987, p. 525).

41. Ver Francesc Gerau (1709).

\section{PRIMEIRA PARTE Emque fe contem muitos Sermoens pertencentes ao Advento, \& Qua- refma com outros adjuntos. \\ 4 .
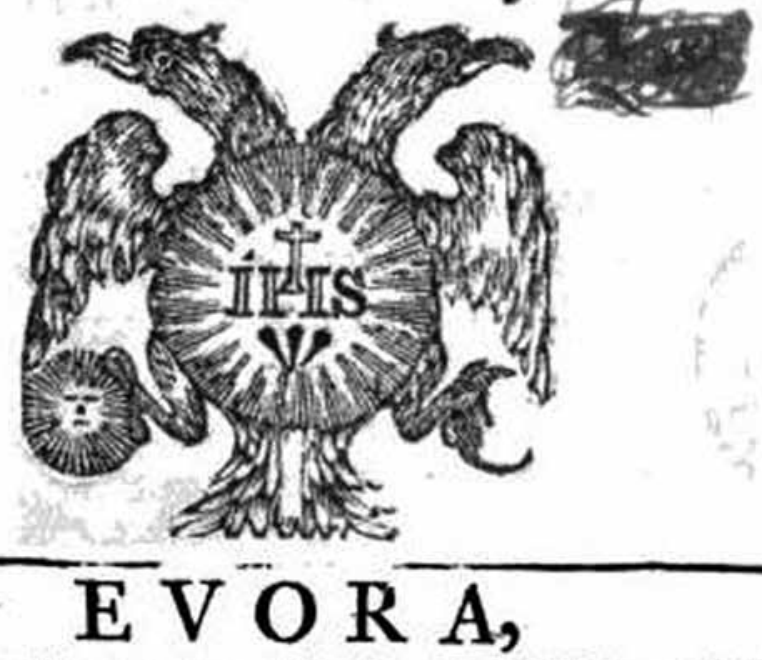 \\ Com todas as licenças neceflarias,na Officina da Uni- verfidade, Anno de M.DCC.XVII.}

Figura 1 - A águia do Império do Mundo, estampada na capa dos Sermoens do Padre Manoel dos Reys, da Companhia de Jesus, editado em 1717 pela Universidade de Évora, Portugal, pertencente à mesma Companhia. Biblioteca Histórica Marqués de Valdecilla, Biblioteca Digital Dioscórides, Universidade Complutense de Madri.

ela traz o sol preso na garra direita e, na esquerda a lua. Essa representação - a bicéfala com o sol e a lua nas garras - é comum em fachadas de templos dos padres eremitas de Santo Agostinho, em Portugal e llhas Atlânticas (e em vários templos dessa Ordem, no mundo hispânico).

É interessante comparar a gravura dos jesuítas portugueses com o símbolo do Colégio Imperial dos jesuítas, em Madri. Foi criado em 1560, e tomou o título de imperial depois de tornar-se o principal herdeiro dos bens da Imperatriz Maria de Áustria, filha de Carlos V, em 1603, quando ela morreu40.

O símbolo do Colégio Imperial de Madri era uma águia bicéfala negra coroada (como a do Sacro Império), tendo dentro do corpo as insígnias da Companhia de Jesus, tal como podemos ver na ilustração da folha de rosto do livro de um jesuíta, teólogo do Colégio de Barcelona; datado de 1709, editado em Madri, pelo impressor Francisco Laso ${ }^{41}$ (Figura 2). A mesma representação que ilustra, em 1702, a parte inferior da folha de rosto dum livro do jesuíta Paolo 


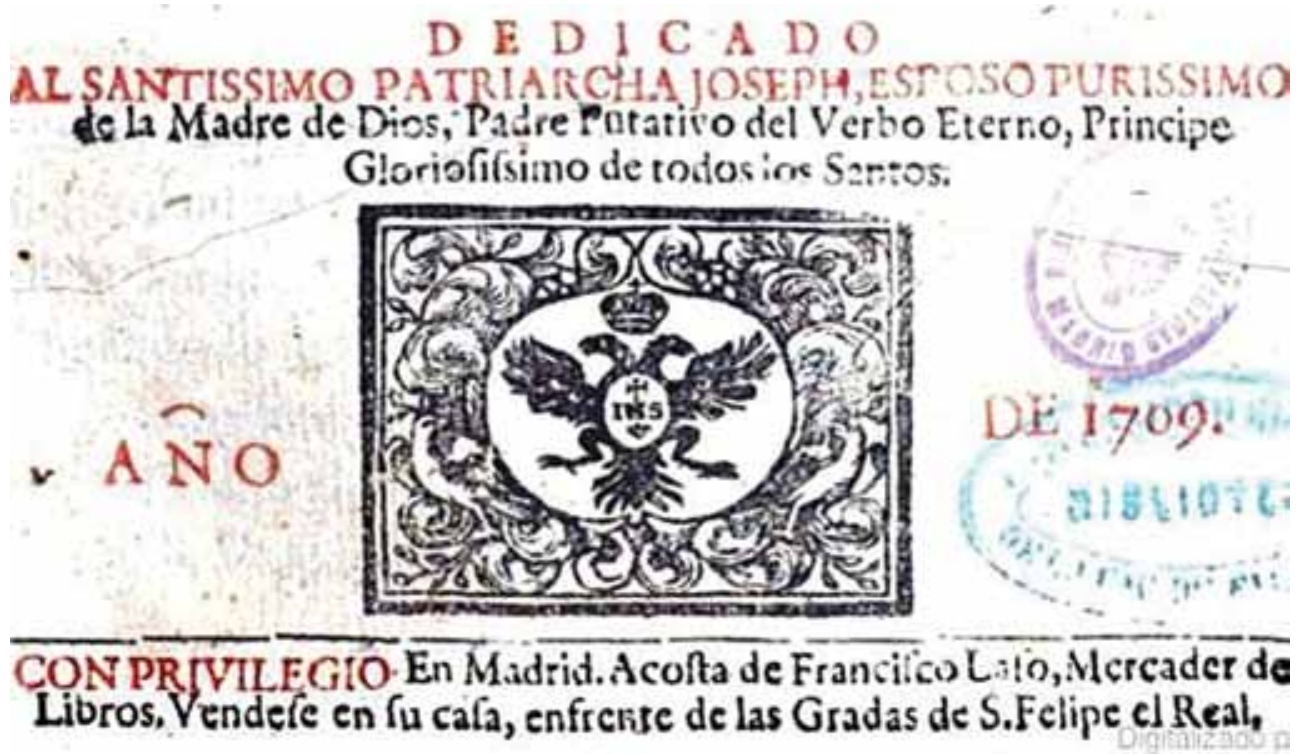

Figura 2 - Detalhe da capa do livro Declamaciones sacras, politicas y morales... (1709), do padre jesuíta catalão Francesc Gerau. Na estampa, a águia do Sacro Império Alemão, em memória da imperatriz Maria Cristina, protege a Companhia de Jesus (emblema do Colégio Imperial dos jesuítas, em Madril e é protegida pelas duas águias dos ramalhetes de flores que envolvem o emblema: as águias imperiais divinas, o Cristo e a Virgem Mãe. Biblioteca Histórica Marqués de Valdecilla, Biblioteca Digital Dioscórides, Universidade Complutense de Madri.

Segneri, "Teólogo da Santidade de Inocêncio XII", numa tradução espanhola, editada em Madri pela mesma casa impressora do livro antes citado ${ }^{42}$. Entretanto, é revelador notar que, em ambos, o escudo do Colégio não aparece isolado: está envolvido, emoldurado por ramalhetes onde pousa, de cada lado, uma águia ${ }^{43}$.

$\bigcirc$ que os jesuítas de Espanha querem mostrar, com as duas águias separadas, envolvendo o emblema-águia do Colégio de Madri? Provavelmente, o mesmo que os jesuítas portugueses do Colégio do Espírito Santo em Évora: o Poder Eterno.

Um terceiro e último caso tipográfico (ainda ligado à Companhia de Jesus e novamente do lado hispânico), é bastante elucidativo em relação ao poder que a figura do império está representando. É uma gravura - sem identificação de sua fonte ou data (fins do século XVII?) - reproduzida - na capa de um estudo sobre imaginária no Rio da Prata, publicado em Buenos Aires, em 1948: uma águia bicéfala imperial, com a coroa entre as duas cabeças. $\bigcirc$ corpo da águia contém a Virgem com o cetro de rainha numa das mãos e, na outra, tem assento o Menino Deus trazendo na mão um globo encimado por uma cruz. Por fim, sob a pata direita da águia, a letra "S" e sob a esquerda um cravo fazendo a vez da letra "I": Societas lesu44. É a Virgem do Rosário. Nela se dá a representação da soberania.

Essa águia imperial devia fincar pé no mundo. É possível, desde já, visualizar a extensão geográfica do fenômeno, em função dos resultados
42. Ver Paolo Segneri (1702).

43. É bom lembrar que, na Espanha, a guerra da sucessão não havia acabado, mesmo que Felipe $\mathrm{V}$ já estivesse no trono, em Madri, onde se consolidou, começando a reinar, na Monarquia Católica, um Bourbon, um francês, neto de Luís XIV, naquela época ainda no trono da França. Felipe Próspero foi afeto, como antes o foram os Habsburgos, à Companhia de Jesus. E, para trono espanhol, os jesuítas haviam alinhado com os Bourbons desde o início da celeuma, em 1700 .

44. Ver Adolfo Luis Ribera e Héctor Schenone (1948). 
45. Cf. Padre Antônio Vieira (1957, p. 149).

46. Ver na nota 12 a informação proveniente de André Grabar (1985) alcançados pelo projeto de pesquisa. Proximamente, essas informações podem engendrar esboços de uma cartografia do símbolo, para se acompanhar e analisar a sua propagação.

Os testemunhos já localizados no decorrer do meu trabalho - e são numerosos - estão espalhados pelos quatro cantos do mundo. Na América portuguesa e hispânica, aparecem no Brasil (Pernambuco, Alagoas, Paraíba e Bahia, Minas Gerais, Rio de Janeiro, São Paulo, Rio Grande do Sul), Argentina, Bolívia, Chile, Colômbia, Cuba, Equador, Estados Unidos da América (região das antigas missões espanholas), Guatemala, México, Nicarágua, Panamá, Paraguai, Peru, República Dominicana, Venezuela; na África (Ilha de Moçambique) e na Ásia (China, India, Filipinas) e no mundo europeu - especialmente no espaço que correspondia às monarquias portuguesa e espanhola e aos territórios italianos sob domínio do Papa.

Agora já é possível tirar esse símbolo da opacidade em que tem permanecido e revelar sua presença em igrejas paroquiais e catedralícias ou nas de diferentes ordens religiosas, em pequenas capelas e oratórios particulares, e nas residências de dignitários eclesiásticos etc. $E$, também, em obras e objetos os mais diversos: decoração arquitetônica (fachadas, portais, arcos de cruzeiro, lavatórios etc.), retábulos e frontais de altares, púlpitos, painéis azulejares, quadros, credências, sacrários, cadeiras; custódias, salvas, lâmpadas, relicários, vasos; paramentos litúrgicos, tapetes, cofres, contadores, grades, potes de farmácia (segundo textos da época, a verdadeira saúde emanava de Cristo, primeiro boticário; a Graça Divina era o remédio da Humanidade) etc.

É no interior de toda a trama cultural e política que se desenrola pela segunda metade do século XVII europeu adentro que ganham sentido as numerosas peças em que aparece esse motivo ornamental. A época é uma só e todas essas peças fazem parte de um jogo, de uma "parada", tanto faz que seja um retábulo numa aldeia jesuítica de Missão no Sudeste do Brasil (Embu, São Paulo), um singelo frontal de altar dum pequeno santuário em Trás-os-Montes, um exuberante púlpito dourado do primeiro momento joanino do Minho, ou uma esplêndida custódia de uma igreja em Santa María de Valtierra, Navarra/Espanha: em toda a parte, a alegoria da águia bicéfala exalta, celebra, adverte. É preciso prestar atenção.

Há, ainda, toda uma produção pictórica e escultórica, de caráter mariano, associada ao emblema da águia bicéfala: a "Mãe Santíssima", conforme se expõe neste texto, é a águia de duas cabeças; a Virgem é o humano tornado divino, tanto quanto deu carne à divindade ${ }^{45}$. Ela exemplifica a lgreja, é o elo de união entre as dimensões espiritual e terrena (temporal) ${ }^{46}$.

Esse conteúdo, esses significados estão na razão direta do fenômeno de sua ampla difusão: a águia bicéfala da época do Barroco é uma representação do universalismo cristão, do poder imperial da lgreja, da profecia milenarista, apocalíptica da Quinta Monarquia, da profecia de Daniel, tão entranhada na cultura do Ocidente, mas representa também o Quinto Império ou Império de Cristo consumado na Terra, este, um complexo programa político-teológico desenvolvido no interior da Companhia de Jesus, que reforça a dimensão 
apostólica, eclesial, do velho projeto da Cristandade: esta é a novidade tanto do símbolo (histórica) como desta análise (historiográfica).

Na poesia ou nas letras "espirituais", os escritores do "tempo barroco" cedo conformam tal versão "ao divino" do poder soberano supremo.

$\bigcirc$ poeta espanhol Alonso de Bonilla y Garzón (1569-1642), famoso em sua época a ponto de ser chamado, por Lope de Vega, "a oitava maravilha do Parnaso", publicou em 1624 um livro em rimas sobre os atributos da Virgem Maria, e dela diz, entre outras coisas (destaques meus):

\section{El infinito y celestial Monarca}

Que enti encerró un abysmo de mysterios,

No es Regulo mendigo, ni es Toparca

Que rige limitados hemisferios:

Pues en tu escudo, por siñal que abarca

De eterno y temporal los dos imperios,

Una Águila pintó con dos cabeças,

Esto es un Dios con dos naturalezas.

Sus blasones magníficos campean

Entre quatro quarteles peregrinos,

llustre cada qual, puesto que sean

Los dos humanos y los dos divinos:

Luzes de eternidad los hermosean

Aunque son diferentes los caminos,

Pues Christo es temporal por lo materno,

$Y$ por linea del Padre, sempiterno ${ }^{47}$.

Quase na mesma época, no âmbito da Companhia de Jesus, o téologo jesuita francês padre Nicolas Caussin, verseja sobre o tema em uma das suas obras mais reeditadas e internacionalmente disseminadas - La Cour Saint (1637-1638)48. $\bigcirc$ padre Caussin é aquele a quem Vieira, na França, expôs a sua doutrina do Quinto Império, deixando-o verdadeiramente impressionado ${ }^{49}$. $\bigcirc$ trecho de verso transcrito abaixo também consta em uma edição espanhola de textos do padre, datada de 1677, com o título de Simbolos selectos y parabolas históricas:

En fin, uniendo el assumpto de Luna, con los dos nombres de muger, y de varon; con los atributos de Diana, y Lucina, y con la cabeça de Ave, diré, que assi mismo es MARIA.

El Aguila Imperial de dos cabeças, unida oposicion de dos grandezas; pues la humildad con el poder la alaba, fortaleza, y muger, Reyna, y esclava;

Madre, y Virgen divina;

Na verdade, o símbolo imperial ou a águia bicéfala é um ponto de convergência das questões relativas à conversão da humanidade à "Lei de Cristo"
47. Cf. Alonso de Bonilla (1624, p. 59).

48. Utilizei uma edição espanhola de 1726; cf. Nicolas Caussin (1726, p. 300).

49. Ver n. 26. 
50. Cf. Padre Antônio Vieira (1957, p. 162-192).

51. No desenvolvimento deste estudo histórico, em que se faz necessário o tratamento iconológico da questão, ou seja, no nível da análise e da síntese (interpretação) iconográficas, o autor atenta para a contribuição de estudiosos das imagens, como Erwin Panofsky e André Grabar com seu "método dinâmico" e também para contribuições recentes, no plano do método, como é o caso dos estudos históricos e metodológicos publicados pelo historiador inglês Peter Burke. No caso de Panofsky, a obra é o clássico Significado das Artes Visuais (1979). No de Grabar, a lição vem da sua última obra de fôlego, Les voies de la création em iconograpbie chrétienne (1979). E também as análises de Peter Burke (2001; 2004), em relação à abordagem das imagens pelos historiadores. Corretamente, Burke veio conclamar os historiadores a usarem as fontes icônicas e artísticas, ressaltando o fato de que a análise pode ser problemática caso tais imagens sejam vistas como mero reflexo da sociedade, e não, como componentes e configuradoras da sociedade onde ganharam existência, como de fato o são. É bastante sugestivo o título que o livro recebeu na sua edição espanhola: Visto y no visto (Barcelona, 2001). e consequente dilatação e expansão da dita fé, isto é, da própria lgreja; questões, portanto, relativas à sua função e finalidade. $\bigcirc$ poder imperial afirmado no símbolo, pairando acima dos poderes políticos estava consubstanciado no dogma do Santíssimo Sacramento: a figura da águia de duas cabeças metaforizava o "Mistério da Fé".

Na sua doutrina escatológico-messiânica da Quinta Monarquia, o conhecidíssimo padre Antônio Vieira - levando em conta que os temas acima citados, além de dizerem respeito ao mundo eclesiástico em geral, também envolviam diretamente e em larga medida, amplos setores das instituições religiosas - antepõe a lgreja Universal "às congregações particulares dela"; antepõe o apostólico ao políitico, como sendo o verdadeiro modo de estabelecer a conversão universal, condição para realizar o Quinto Império ou Império de Cristo Consumado na Terra, ou seja, a remissão do mundo ${ }^{50}$.

Este estudo iconográfico sobre a figura da águia bicéfala que materializa o sentido imperial da Igreja Católica, dá um primeiro passo para divulgar e estabelecer um problema histórico nunca antes tratado.

Embora essas manifestações artísticas identificadas já apontem, no que diz respeito à sua composição e organização formal, para outros significados além dos que convencionalmente veiculava o símbolo do Sacro-Império (isto é, se prestem a análises que resultam úteis à interpretação), a ênfase nesta primeira abordagem do fenômeno é em relação aos conteúdos, aos significados novos que apresenta, do ponto de vista social e ideológico, buscando interpretar a mudança ocorrida no tema, sua função e significado histórico.

Qual o significado desse deslocamento do símbolo de império do plano político para o religioso? Para responder a esta indagação, buscou-se detectar os conteúdos dos textos espirituais e políticos - textos e gravuras ilustrativas - que falassem a respeito da idéia de poder universal - de império e de monarquia universal, ou versassem a respeito disso. Doutra parte, sem um levantamento amplo de ocorrências do motivo iconográfico no mundo cristão dos séculos XVII e XVIII, não seria possível perceber a dimensão do fenômeno. E isso importa para que se torne mais claro o significado, em campo religioso, dessa figura de império Resta, sem dúvida, muito a pesquisar e estudar.

No nível iconográfico ${ }^{51}$, visto em sua dinâmica, para ser empregado em campo exclusivamente religioso, o símbolo de império encontrou correspondência com temas internos à Igreja. Das Escrituras Sagradas, da Patrística e dos textos proféticos extraiu-se o conteúdo apropriado para representar a "Igreja do Cév e da Terra" (triunfante e militante) como o império ao qual todos seriam sujeitos: a afirmação da supremacia da soberania divina sobre a temporal assenta-se no mistério do altar, a Eucaristia, referindo à Encarnação e Ascensão do Cristo, e à Assunção da Virgem. O tema da Salvação é central no Cristianismo: o Reino de Cristo expresso no Apocalipse, o Júzo Final.

A figura da águia do Império, ao ser trasladada para o âmbito eclesiástico, manteve e ajustou, aos novos conteúdos, os significados correntes que perduravam havia séculos: a representação do domínio do Nascente e do 
Poente, isto é, do mundo todo - o "império do mundo"; e, também, a representação da função do Império Cristão como cuidador e defensor do temporal e do espiritual ${ }^{52}$.

Quando nasce essa iconografia sacra? Seu significado eucarístico já está presente em uma data recuada ao último terço do século XVI: ganha corpo durante a Festa do Corpo de Deus realizada na Cidade do México, em um ano que pode ser o de 1574, como se vê mais adiante.

Tais figurações da águia bicéfala indicavam, conforme o exposto, situações e ações de teor ideológico, religioso. Mas também o político revelou-se, obtida a chave de leitura dos códigos perdidos, ao rastreá-la e analisá-la no nível religioso e ideológico, de meados do século XVII em diante. No sentido inverso, situações, ações e ideias de ordem político-teológicas levam, no tempo, a emblematizações, a alegorizações: o projeto do Quinto Império de Cristo Consumado na Terra não ficou apenas na ideia, mas implicou programas de ação, adesões, bandeira de luta. Um imenso caudal a ser investigado.

Conhecer as obras, os produtos, as formas, significa ir em direção às vivências, no interior das relações sociais, políticas e econômicas que estruturam as sociedades ${ }^{53}$.

A historiografia e o emblema

Dentre as muitas obras portadoras desse símbolo até agora identificadas (já são mais de mil e quinhentas peças), a maioria delas datadas dos anos 1680 em diante, apenas algumas poucas são conhecidas e, nos últimos 60 anos, têm sido mostradas em publicações diversas, com a indicação corrente de tratar-se da "águia dos Habsburgos", a "águia dos Áustrias" ou "dos Filipes". É assim que o símbolo tem sido classificado por historiadores de arte hispânica ou hispanoamericana e de arte portuguesa (do continente e antigo ultramar).

Às vezes, ao depararem com esse emblema de ordem imperial apresentando no centro um coração trespassado por uma seta em templos da Ordem dos Eremitas Calçados de Santo Agostinho (entre os Descalços ou Recoletos, também a encontramos), foi indicado como emblema da sobredita Ordem, como ocorreu, por exemplo, com a águia em relevo na fachada do Colégio da Graça ${ }^{54}$, em Coimbra, ou a existente na da igreja de Nossa Senhora das Mercês, em Évora (Figuras 3, 4 e 5), ou no fecho do arco-cruzeiro da igreja dedicada ao Santo Doutor da Igreja, em Macau (China) - e, mesmo em casos como esses, muitas vezes a figura tem sido identificada como "Águia dos Áustrias".

fato é que, do ponto de vista formal, a associação desse motivo com a águia dos Áustrias, por datar de uma época em que os membros dessa família ainda eram grandes cabeças coroadas, gerou uma explicação mecânica do fato e, ao mesmo tempo, eximiu de maiores atenções e análises o fenômeno. Ora, apenas os Áustrias alemães estavam de posse do emblema, e não devido ao apelido Habsburgo, mas como Imperadores do Sacro Império Romano
52. Cf. Diego de Yepes (1592, p. 104).

53. São oportunas as observações de Antoine Prost, de que o historiador não poderia decifrar os elementos da cultura sem "transitar constantemente da experiência ao discurso sobre a experiência [...] porque é impossível compreender uma representação sem saber de que é ela representação, sob pena de se perder no nominalismo"; cf. Antoine Prost (1998, p 136). Na mesma obra, $\mathrm{Kr}$ zysztof Pomian, no artigo, História Cultural, História dos semióforos, conclui que "legitimamente, não se podem encarar os objectos independentemente dos homens que, ao servirem-se deles, lhes conferem funções e, no caso dos semióforos, significados. Mas pela mesma razão os homens e os seus comportamentos não poderiam ser encarados sem os objetos de que se servem e que co-determinam o seu lugar na hierarquia social, os seus papéis e as suas identidades"; Cf. Krzysztof Pomian (1998, p. 95).

54. Em Coimbra, Portugal, o Colégio da Graça, dos Eremitas de Santo Agostinho, ostenta na fachada um robusto emblema formado pela águia bicéfala coroada, tendo ao centro o coração trespassado; pousa a garra esquerda no sol e a direita na lua. É obra da segunda metade do século XVII. 


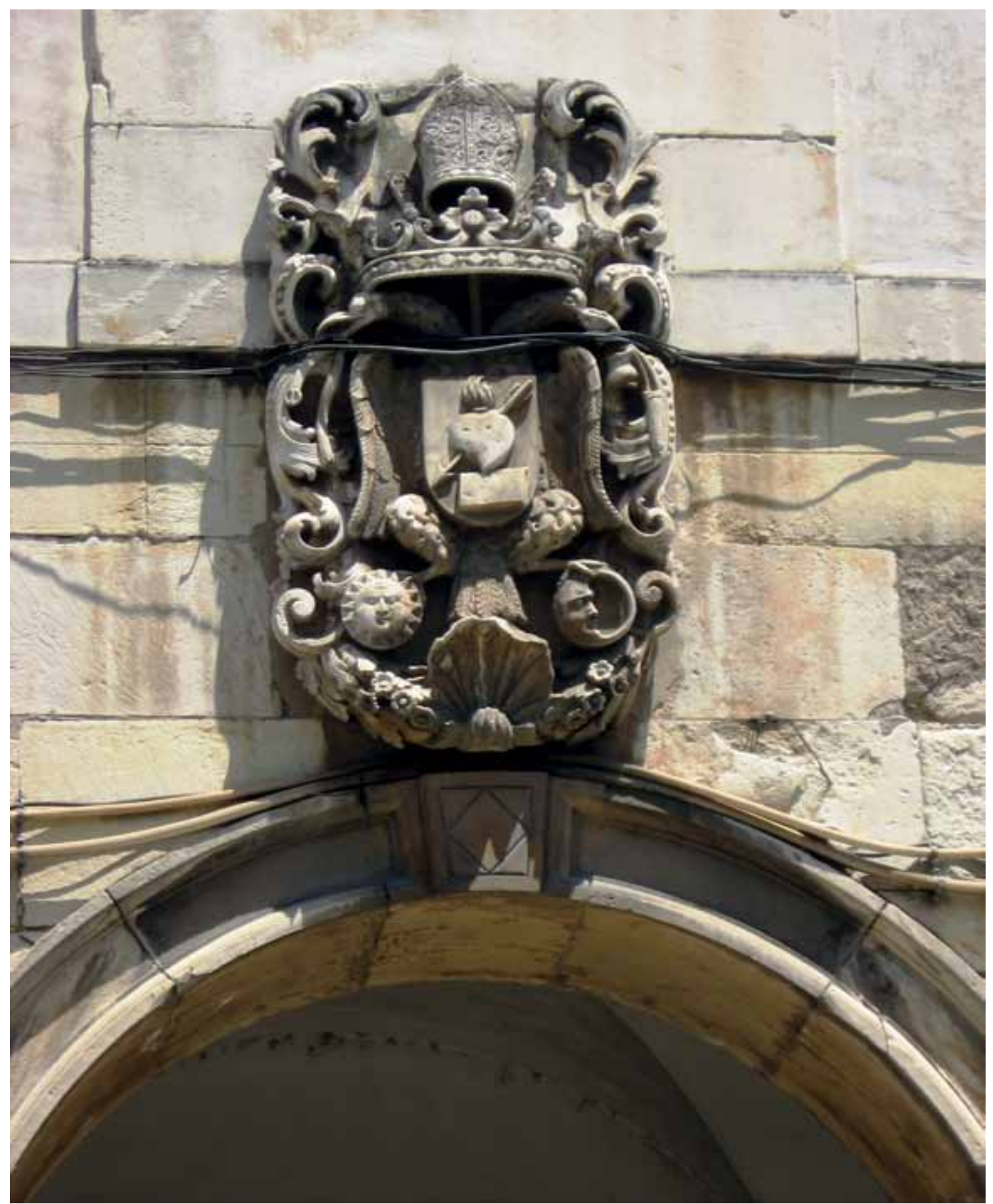

Figura 3 - Insígnias da Ordem dos Eremitas Calçados de Santo Agostinho associadas ao símbolo imperial (águia bicéfala coroada) em campo religioso, na fachada correspondente à Portaria do Colégio de Nossa Senhora da Graça, em Coimbra, Portugal. O sol numa das garras e a lua, noutra, eram representações correntes do Cristo (Sol) e da Virgem Mãe (Lua). Fotografia de Jaelson Bitran Trindade, 2006. 


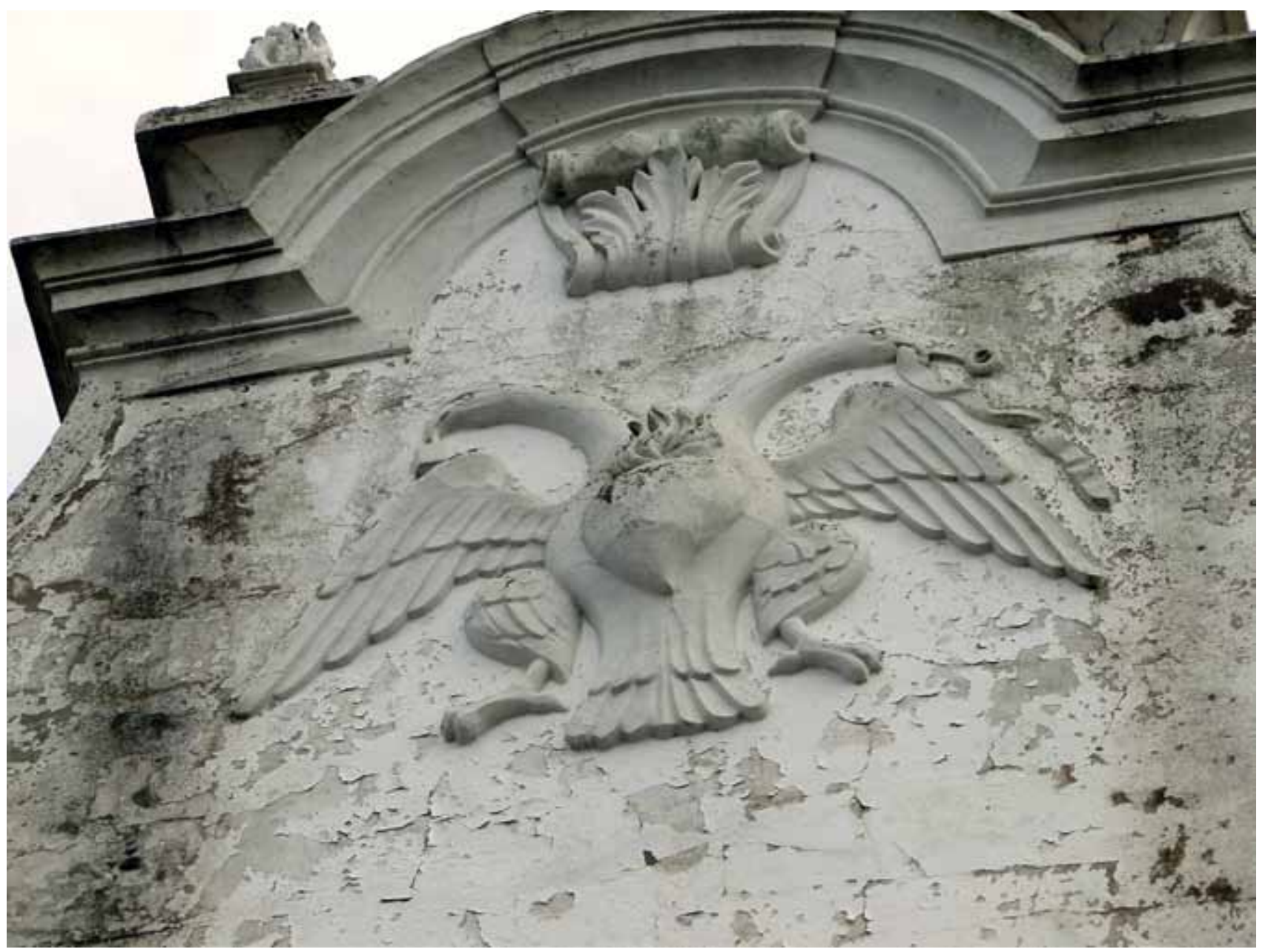

Figura 4 - Uma águia bicéfala em relevo orna o centro do frontão da igreja do convento de Nossa Senhora das Mercês, da Ordem dos Padres Descalços de Santo Agostinho, na cidade de Évora, Portugal. As obras de construção ocorreram no último quarto do século XVII. Fotografia do arqueólogo António Carlos Silva, Évora, 2010 (cortesia). 

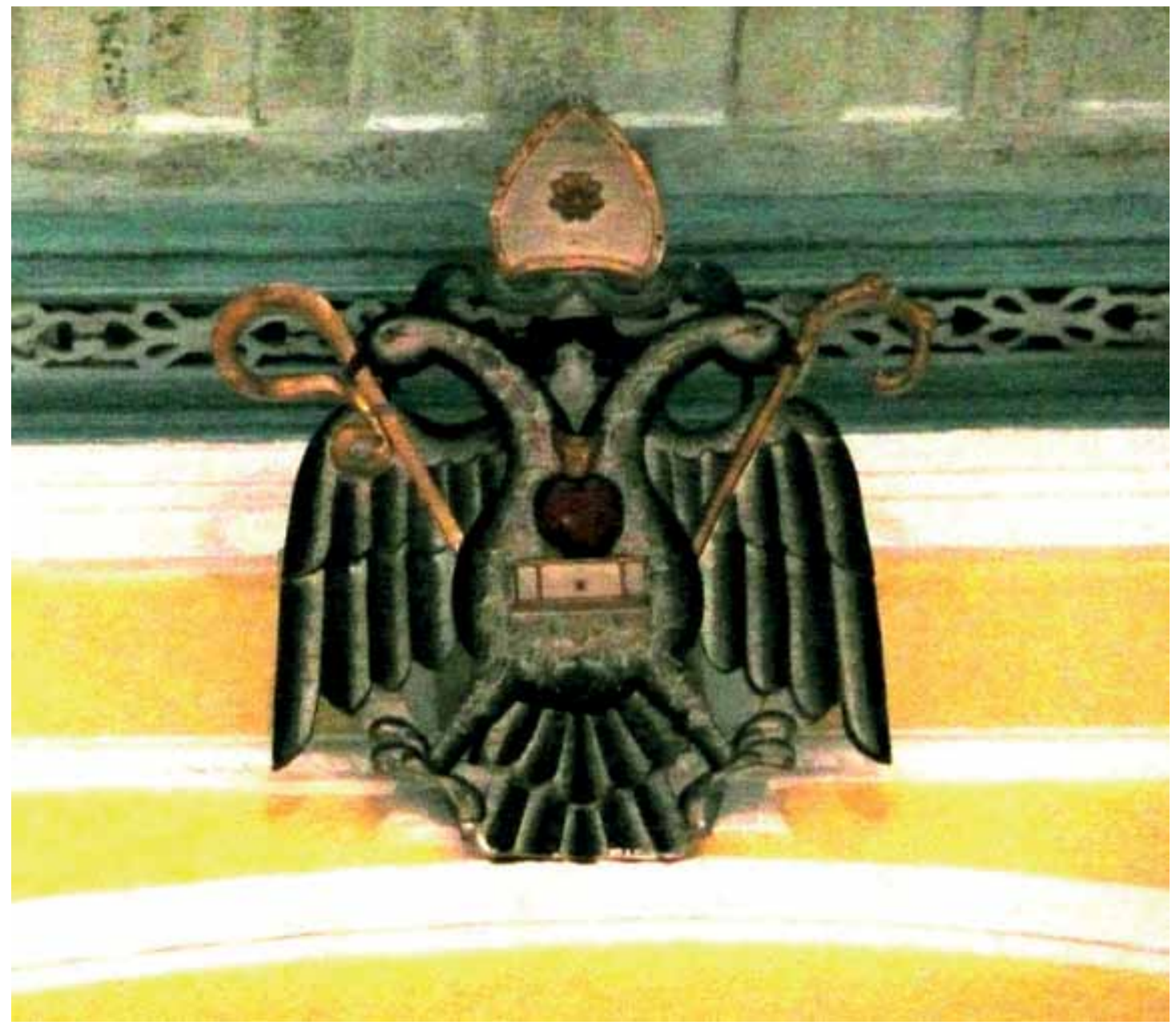

Figura 5 - O coração, atributo dos padres agostinhos, envolvido pela águia bicéfala. Fecho do arco-cruzeiro da igreja de Santo Agostinho, em Macau, China. Século XVII. Fotografia de José María Vidal, 2007 (cortesia).

Germânico. Inadvertidamente, continua-se a afirmar que a dupla águia é insígnia da Casa dos Habsburgos, porém, a histórica cota de armas dos Habsburgo era, e é, um leão rampante (firmado nas patas traseiras) sobre um fundo dourado. A águia bicéfala, repita-se, é o signo do Sacro Império e sua representação começara a aparecer, com assiduidade, desde a entronização, no Império, da Casa de Hohenstaufen (1 138-1254), no início do século XIII.

Visto, assim, de maneira isolada, os historiadores nem sequer se perguntaram como era possível um símbolo que eles associam a uma dinastia (Habsburgos) - e não o é, como ficou dito no parágrafo anterior - estar fixado em elementos permanentes e fundamentais da liturgia e dos dogmas da Igreja, como custódias, púlpitos, retábulos, oratórios de mesas, cabeceiras de camas de dignitários eclesiásticos e em vários outros objetos. E não se levou em conta o fato de que, do puro ponto de vista cronológico, desde a segunda metade do século 
XVI (1556), a águia bicéfala não mais poderia constar entre os símbolos da monarquia espanhola, como emblema dos reis de nome Filipe, seja no continente europeu ou em seus domínios americanos, o mesmo ocorrendo em relação a Portugal e seus domínios quando da União das Coroas (1580-1640).

A partir de 1520, quando Carlos I, rei de Espanha, foi coroado imperador do Sacro Império, estatuto político mais amplo, a águia bicéfala do Sacro Império passou a envolver o escudo da monarquia espanhola. Mas, em 1556, com a renúncia de Carlos V, imperador e rei de Espanha, a ambas as coroas, os símbolos desvincularam-se e a monarquia espanhola passou, desde então, a exibir apenas o seu escudo, sem a águia. Desde meados do século XVI, portanto, o mundo espanhol não estava mais incluído no Sacro Império (Fernando, irmão de Carlos V ficou com a coroa imperial - os ditos "Filipes", filho e netos de Carlos, nunca foram imperadores da Cristandade).

Algumas ocorrências brasileiras remanescentes desde há muito chamaram a atenção de três estudiosos deste país, exatamente pela sua raridade: justamente o arquiteto brasileiro Lúcio Costa, o norte-americano Robert Smith e o francês Germain Bazin, que nas décadas de 1940 e 1950 elaboraram as grandes sínteses da arte luso-brasileira. Costa e Smith não hesitaram em afirmar que as águias bicéfalas encontradas eram a "águia dos Filipes" - e a historiografia subsequente não fez mais do que repetir essa ideia ${ }^{55}$. Ou, ainda, ao depararem (Lúcio Costa e Germain Bazin) com uma peça cuja datação era documentadamente de fins do século XVII, pós-Felipes, lançaram a ideia de que o emblema teria sido empregado "como simples motivo ornamental"56, outra linha de explicação que também tem sido aceita sem discussão.

Até recentemente, foi Bazin que nos deu a conhecer o maior número de informações sobre a ocorrência desse motivo na arte luso-brasileira. Em Architecture Religieuse Baroque au Brèsil57, ao apreciar os altares colaterais da igreja jesuítica de Nossa Senhora do Rosário, da antiga aldeia de Embu-Mirim, e o púlpito da capela rural de Santo Antônio de Lisboa, em São Roque, nas redondezas da cidade de São Paulo, lembrou eventos similares no Nordeste do Brasil e em Portugal.

Bazin, prudentemente, não lança tudo à conta dos Felipes, monarcas espanhóis do ramo Habsburgo alemão. Verifica que não é possível recuar a data dos dois altares colaterais do Embu para trás dos primeiros anos do século XVIII, quanto mais para antes de 1640, fim do Brasil Filipino ${ }^{58}$, razão pela qual vê ali apenas um tema heráldico usado como adorno ou símbolo; e pergunta: "Não é o emblema da Ordem Agostiniana"? Conjeturando, ele identifica o caso dessa igreja jesuítica com algo já conhecido, com "a soberba águia bicéfala que sela a fachada e o arco-cruzeiro de São João Novo do Porto", igreja que sabe ser dos Eremitas Descalços de Santo Agostinho. E conclui que a insígnia da igreja portuense é uma alusão a Santo Agostinho, é "tão-somente a insígnia da 'águia de Hipona'". Na mesma linha de raciocínio, ele estabelece que as águias bicéfalas decorando púlpitos tais como o de uma capela privada paulista (Capela de Santo Antônio de Lisboa, em São Roque) e o da lgreja da Misericórdia, de
55. A ideia de hispanidade dessas águias bicéfalas encontradas em São Paulo foi reafirmada por outros pesquisadores, como Aracy Amaral (1981, p. 98); e, em alguns de seus escritos e ainda bem recentemente, Carlos Lemos (2008, p. 112113). Depois de insistir na ideia de que as águias bicéfalas no centros dos altares colaterais da igreja da antiga aldeia jesuítica de Nossa Senhora do Rosário do Embu são as "dos Habsburgos austríacos" com "uso meramente decorativo", Carlos Lemos conclui dessa maneira a breve apreciação daquele símbolo: "Na verdade, nunca saberemos que motivos ou conceituações levaram os artífices do mundo jesuítico de São Paulo do Campo de Piratininga a pespegar em suas talhas a águia de duas cabeças, que sempre simbolizou duas virtudes ou dois poderes em um só corpo".

56. Cf. Lúcio Costa (1978, p 97).

57. A obra de Bazin, em dois volumes, só foi publicada no Brasil em 1983.

58. A mesma "prudência" não se vê na historiografia em geral, que continua vendo nas águias dos altares colaterais do Embu a "águia dos Filipes", por isso não se hesita em datá-las como do tempo do Domínio Espanhol (1580-1640), apesar de ter o estilo nacional português de que ambos os altares são exemplos tardios - surgido em Portugal por volta da década de 1670; além do mais, a luta dos portugueses para se emanciparem do jugo espanhol tornaria inaceitável o uso de símbolos régios da Espanha nos anos que se seguiram à Restauração (1640); ou, ainda, por estarem em lugar de alto teor sagrado. $\mathrm{O}$ mesmo ocorre em relação ao púlpito da capela seiscentista (1681) localizada na área rural do município de São Roque, próximo ao Embu. Tais interpretações permane- 
cem na historiografia recente, indicando obras tão singulares e importantes (como os já citados altares colaterais e púlpito) como peças antigas "do tempo dos Filipes”, reaproveitadas em época posterior. Um exemplo disso pode ser encontrado em Percival Tirapeli (2001, p. 75,94 e 164 )

59. Não encontrei estudos históricos a respeito de transformações ocorridas na heráldica da Ordem de Santo Agostinho. As pesquisas iconográficas que realizei, porém, mostram que, nos séculos XVI e XVII, o emblema que predomina na Europa, é o do coração flamejante e flechado sobre o livro aberto, sem águia bicéfala como contorno.

60. Cf. João Francisco Marques (1989, p. 176); grifos meus. Como regra, no presente estudo, as transcrições tiradas de fontes antigas, manuscritas e impressas, não guardaram fidelidade à ortografia original, salvo no que se refere á pontuação e ao uso de maiúsculas, mas não de modo global, isto é, desde que medida não dificultasse o entendimento do leitor atual; no mesmo sentido, as abreviaturas foram desdobradas.

61. Cf. Germain Bazin (1957, p. 292).
Olinda, Pernambuco, são uma alusão a Santo Agostinho, devendo significar "o voo da eloquência".

Aqui, cabe uma ressalva: o emblema da Ordem Agostiniana geralmente era formado por um coração flamejante atravessado por uma seta, sobre um livro aberto - uma investigação alargada evidencia isso ao investigador que quer enfrentar o tema. A colocação desse emblema no interior de uma águia bicéfala é fato contemporâneo à difusão das teses quinto-imperiais, na segunda metade do século XVII, fato que passou despercebido de Bazin ${ }^{59}$. É sintomática a colocação, na década de 1670, de uma águia bicéfala na portada da igreja de Nossa Senhora da Graça, do convento de Santo Agostinho que está diante do Paço dos Duques de Bragança, em Vila Viçosa:

Que eu espero que ou a um, ou a outro gigante invencível da nossa Vilaviçosa - sede da Casa de Bragança - seguirão muitas gentes em poderosas armadas para conquistar o mundo, e dar cumprimento inteiro ao império dilatado que ao nosso maior gigante da nossa $\mathrm{Vi}$ laviçosa tem Deus e o Céu prometido (Frei Luís de Sá, em 1640, vaticinando diante de D. João IV, Duque de Bragança, o Aclamado, na cidade de Lisboa) ${ }^{60}$.

Fato ainda ignorado é que, além dos agostinhos, também os padres jesuítas - especialmente estes - e alguns setores dos dominicanos, primeiros difusores da devoção do Rosário da Virgem, também colocaram, na mesma época, a águia bicéfala em diversas igrejas de seus conventos ibéricos e hispanoamericanos. $\bigcirc$ mesmo acontecendo com mercedários, franciscanos, carmelitas e cistercienses, entre outros.

Nos demais casos brasileiros que identificou (e que não se enquadram na explicação acima), Bazin acreditou que representassem um uso da figura "como tema decorativo"; assim the parece "a águia dupla" que existiu na antiga fachada da já citada igreja da Misericórdia de Olinda, outra numa fonte da sacristia da Santa Maria dos Anjos, em Penedo, Alagoas e a que rematava um altar de uma capela de engenho de açúcar, em João Pessoa, Paraíba, "cercando um sol com as palavras 'Ave Maria'", já desaparecida na época das suas pesquisas ${ }^{61}$.

Sem dúvida, há associações - que o historiador francês não vislumbrou - entre as diversas águias bicéfalas citadas e as que aparecem em templos e objetos pertencentes à Ordem dos agostinianos, e Santo Agostinho, a Águia de Hipona, a eloquência máxima da palavra da fé cristã, teórico não só dos dois poderes - o divino e o temporal - mas também da realização da Cidade de Deus na terra (a Jerusalém Celeste se identifica, no texto agostiniano, com a lgreja), mas não são referências diretas à Ordem ou a Santo Agostinho. Além disso, vale notar que os emblemas da águia bicéfala com as insígnias da Ordem - que passam a figurar com destaque em muitas de suas igrejas - são da mesma época que as das demais igrejas, de outras congregações: a igreja agostiniana de São João Novo, no Porto, por exemplo, só foi concluída em 1689.

O afloramento de tantas representações da águia bicéfala no universo religioso dos frades agostinhos durante o período aqui estudado merece uma investigação mais cuidadosa. Não está ausente da questão, por suposto, a força, 
dentro da Ordem de Santo Agostinho, de uma corrente joaquimita purificadora da lgreja e agente de uma futura ldade de Ouro da Humanidade, quando se realizaria o reinado do Espírito Santo, corrente que se fortalece no decorrer do século XVI; nem o pensamento agostiniano da descida de Jerusalém à Terra - foi sob a proteção do conspícuo joaquimita cardeal Egídio de Viterbo, da Ordem de Santo Agostinho, que seu confrade, padre Silvestre Meuccio publicou pela primeira vez as profecias do abade Joaquim de Fiore que estavam circulando manuscritas $^{62}$, reavivando internacionalmente o interesse por elas.

Na profecia do abade cisterciense Joaquim de Fiora, que ainda na Idade Moderna inspirava algumas parcelas dos padres agostinhos - como também ocorria com franciscanos, beneditinos e carmelitas, entre outros, assim como com a nova ordem dos inacianos, a Sociedade de Jesus -, ficava marcado que a "chegada do terceiro período, o advento do Império do Divino do Espírito Santo, dependeria do surgimento de duas ordens, a dos contemplativos, que poderia ser representada pelos beneditinos, agostinianos ou franciscanos, e a dos homens de ação, encarnados, agora, pelos jesuítas"63.

A Encarnação do Verbo Divino, a comunhão que cria a Virgem e a Igreja de Cristo no Mundo, o ato com o qual se agracia a Humanidade com a Redenção, a Ressurreição, tem especial lugar no pensamento agostiniano. $\mathrm{Na}$ Ordem dos padres agostinhos, o culto à Virgem da Graça tem lugar privilegiado.

Robert Smith, investigador atuante entre fins de da década de 1940 e início da de 1960, autor do primeiro estudo de conjunto sobre a talha barroca em Portugal, ficou ora na explicação filipina ${ }^{64}$, ora na decorativa, mesmo diante de uma obra - que certamente conheceu - como o esplêndido púlpito joanino (início do século XVIII) com a águia bicéfala entalhada na face fronteira, da igreja de Nossa Senhora do Terço em Barcelos, no Minho português (Figura 6).

fato é que, nos últimos 50 anos, o tema não foi objeto de nenhuma consideração nova, nem de um estudo efetivo no campo da historiografia artística, cultural ou política. É caso isolado o artigo da historiadora da arte Maria del Carmen Heredia Moreno, publicado em 1996 no Archivo Español de Arte ${ }^{65}$. Trata-se de um esforço de interpretação de algumas custódias espanholas que trazem a águia bicéfala coroada - em geral, colocada como um grande nó do hastil que sustenta a luneta de vidro -, lavradas entre o último terço do século XVII e aproximadamente o ano de 1715, além da conhecida custódia de Popayán (Colômbia), cuja data apurada é o ano de 1673 (Figura 7).

É interessante a associação que a autora estabelece entre essas águias e um livro, publicado em 1640 pelo padre jesuíta Francisco Aguado66, onde vem estampada uma alegoria (Figura 8) com as armas reais da Espanha envolvidas pela águia bicéfala que sustenta o mundo onde reina o Santíssimo Sacramento, ou a Fé de Cristo (uma custódia). É, conforme a interpretação da historiadora Heredia Moreno, uma alegoria em defesa da fé católica no mundo: a devoção ao Santíssimo Sacramento dá poder ao soberano espanhol para vencer seus inimigos.

A meu ver, não se trata de uma alusão ao escudo imperial de Carlos V, como se afirma no artigo, pois trata-se do escudo do reino de Espanha, ainda
62. Cf. François Secret (2001, p. 122).

63. Marilena Chauí, apud Leandro Henrique Magalhães (2009, p. 216). Sobre o joaquimismo e sua influência na cultura portuguesa, ver em especial Manuel J. Gandra (1999); e António José Saraiva $(1973$, p. 575-579).

64. Em 1950, Robert Smith publicou, no periódico Belas Artes, um extenso artigo sobre a arte dos retábulos em Portugal entre 1600 e 1750 ; cf. Roberto Smith (1950). Há outro trabalho seu, mais volumoso, em que pode ser lido um ligeiro comentário a respeito da figura da águia bicéfala encontrada nas obras de talha, artísticas, que estudou do período; cf. Roberto Smith (1962, p. 53).

65. Cf. Maria del Carmen Heredia Moreno (1996, p. 183 194).

66. Idem, p. 191. O livro citado, do padre jesuíta Francisco Aguado, insiste, na dedicatória, na exaltação do Santíssimo Sacramento, "único aliado capaz de vencer aos inimigos de Espanha nestes momento difíceis e a cujo fervor devia o monarca seu poder". Ver Francisco Aguado (1640). O Padre Francisco Aguado gozou de grande prestígio junto à Corte de Madri, tendo sido duas vezes Provincial da Província de Toledo e predicador do Rei Felipe IV, além de exercer grande influência sobre o todo-poderoso "valido" do Rei, o conde-duque de Olivares, de quem foi confessor. 


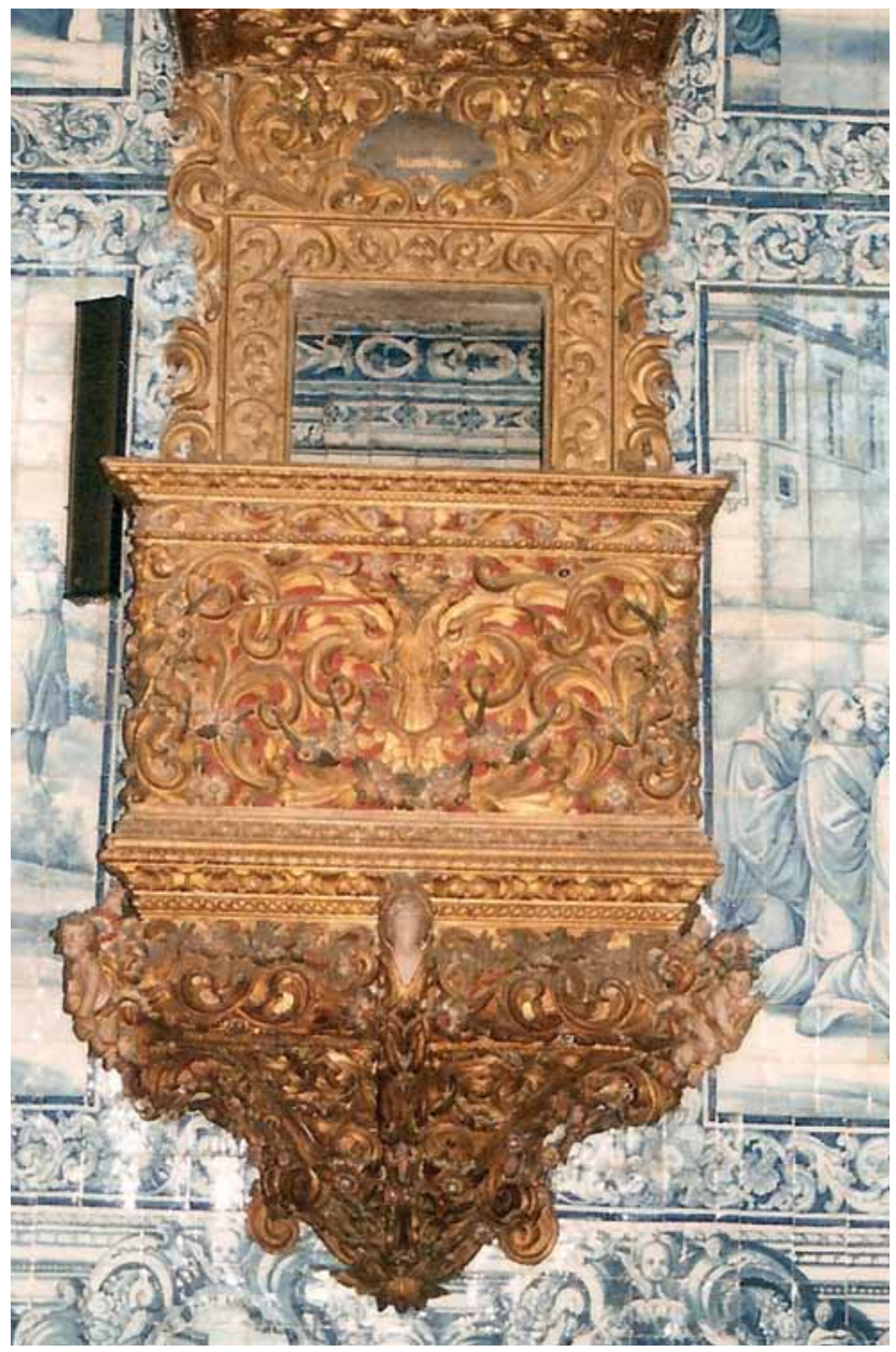

Figura 6 - Púlpito da igreja de Nossa Senhora do Terço (c. 1713), do convento de freiras beneditinas em Barcelos, Portugal. No centro da face frontal, a figura da águia bicéfala. Cortesia dos Serviços de Turismo da Câmara Municipal de Barcelos. 


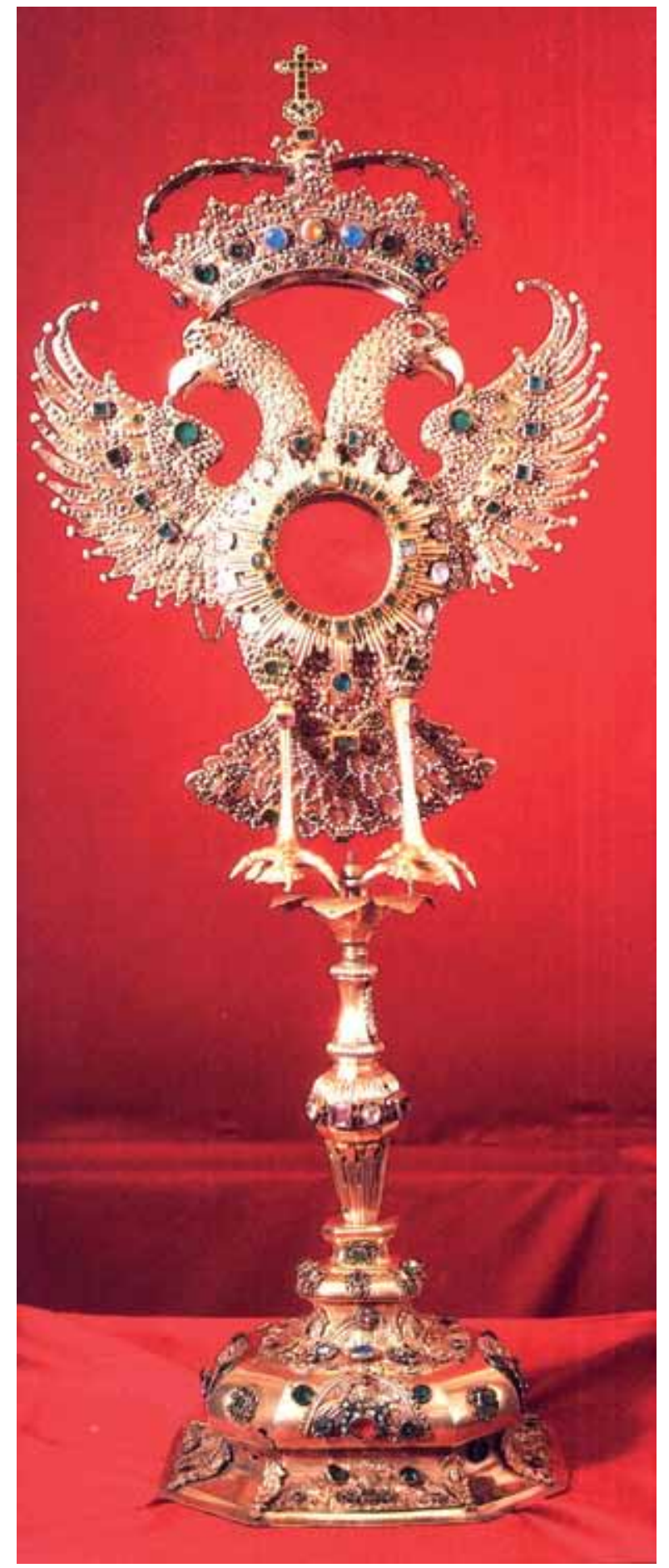

Figura 7 - Essa custódia (ou ostensório) de prata dourada e adornada de pérolas e pedras preciosas, datada de 1673, pertenceu à igreja de Santo Agostinho, na cidade de Popayán, Colômbia. Hoje, figura como obra de destaque na exposição permanente do Museo de Arte Religioso de la Arquidiocesis de Popayán. A águia bicéfala também aparece na decoração de retábulos tanto na igreja dos Carmelitas como na La Ermita, daquela mesma cidade colombiana. A obra tem $0,96 \mathrm{~cm}$ por 0,38 $\mathrm{cm}$. Fotografia cedida pelo Arcebispado de Popayán (cortesia). 


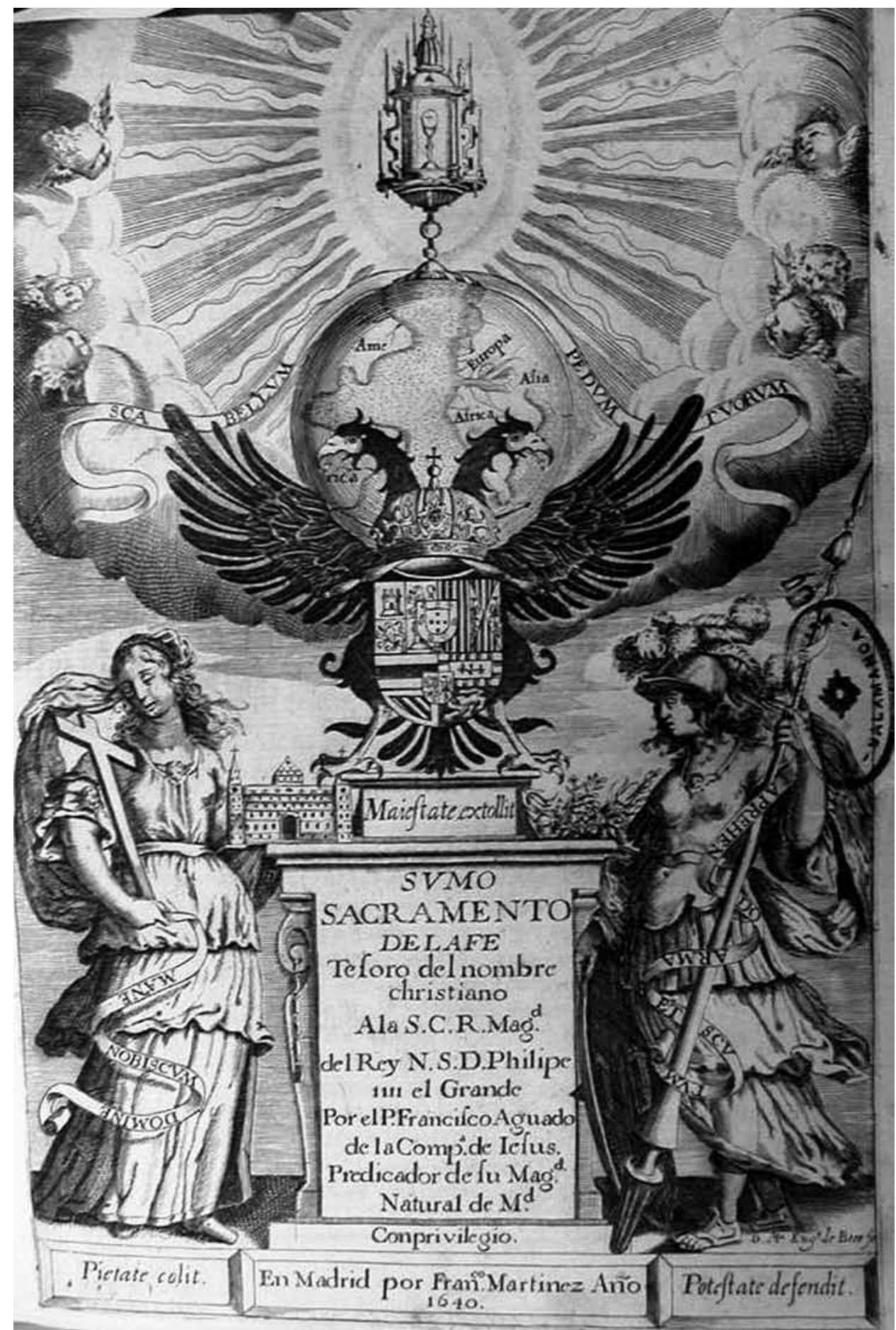

Figura 8 - Portada do livro do Padre Francisco Aguado, Sumo sacramento de la Fe tesoro del nombre Cristiano..., publicado na Espanha em 1640. Gravura de Maria Eugenia Beer. Fotografia de Jaelson Bitran Trindade, 2005. 
contendo as armas de Portugal. A águia bicéfala já contivera o escudo da monarquia espanhola quase cem anos antes, quando a coroa de Espanha estivera subordinada ao Sacro Império Germânico, status político maior. À época dessa gravura (1640), a Espanha era uma monarquia poderosa, seus reis provinham da dinastia que reinava no trono de Viena (os Habsburgos), mas era independente - a águia era, naquele instante, apenas e tão somente o símbolo da Coroa alemã.

Talvez a alegoria apontasse para uma virtual transferência da sede do Sacro Império de Viena para Madri, com a esperança de serem as armas reais espanholas futuramente as armas imperiais ou cesáreas; afinal, as pretensões a monarca universal, à posse de imensos domínios, não eram coisas descartadas pelos Áustrias espanhóis. De qualquer modo, a associação entre a estampa de 1640 e as custódias não pode ser direta, linear: numa peça litúrgica fundamental como a custódia, associada ao ato do "divino Sacramento" da Eucaristia, a águia bicéfala não pode estar aí para lembrar que os Áustrias defendem o dogma.

No caso das citadas custódias-águias, vale registrar o que escreve o padre Antonio Muxica, da Ordem de Nossa Senhora das Mercês, na Espanha, numa publicação datada de 1728: a custódia porta "o Imperador do mundo"67.

As obras: o Evangelho e a Salvação - o Rosário da Virgem

Se a águia presente nas custódias hispânicas - ou mesmo a da alegoria publicada em 1640 - não é um emblema monárquico, ou seja, a águia dos Habsburgos, então o que ela representa? Mais imediatamente, vê-se que essa águia acompanha o surgimento e a proliferação de uma iconografia relativa ao "Triunfo da Fé" ou "Triunfo da Eucaristia" e de uma renovação da imagem da Virgem-Mãe com o Filho, da Rainha dos Céus e dos Anjos, combinando sua imagem ao Rosário, relação com a humanidade, que ganha corpo no decorrer do século XVII.

A devoção ao rosário da Virgem foi ponto de união entre diferentes ordens missionárias. Os padres pregadores (dominicanos), que introduziram e implementaram o culto, foram dele militantes ativos, criando numerosas confrarias. Os jesuítas "roubaram-lhes" a flâmula, sobretudo o padre Antônio Vieira, que orquestrou com a Companhia uma investida global, incentivando as orações do rosário nas ruas, nas casas, nas embarcações, nos templos etc., ganhando adeptos em outras congregações ${ }^{68}$. E os agostinhos não ficaram de fora desse movimento espiritual e privilegiaram em sua Ordem o culto ao rosário, chegando a regulamentar essas práticas a partir da década de $1670^{69}$.

Parece-me que tenho mostrado, com o testemunho das Escrituras, com a doutrina dos santos e com a evidência das razões, quão própria e singular virtude é a da devoção do Rosário para conseguirmos nesta vida a guarda e observância dos preceitos divinos, da qual precisamente depende a bem-aventurança da outra, para que fomos criados todos, e tantos perdem por sua culpa. Mas a prova mais legal e demonstrativa deste glorioso argumento não quis a Virgem Santíssima que ficasse ao discurso dos pregadores, nem à piedade dos seus
67. Cf. Antonio Muxica (1728, p. 93).

68. Ver Paulo Castagna (1999).

69. Ver Ángel Martínez Cuesta, (2007). 
70. Ver Padre Antônio Vieira (1965b).

71. Cf. Padre Antônio Vieira (1965c, p. 17 e 34).

72. Idem. Ver também o capítulo 1: "Argumento do sermão: comparada a devoção do Rosário com a de toda a lgreja, em algumas circunstâncias muito notáveis dela, faz mais um devoto do Rosário em particular que toda a Igreja Universal em comum". Em 1686 saiu a 1. edição em português do primeiro tomo do sermonário rosariano Maria Rosa Mystica. O segundo tomo saiu em 1688.

73. E Vieira continua: "E se os anos que se meditam e tornam a meditar se vivem $\mathrm{e}$ revivem em um dia, que vidas e que anos serão os que vive em um só dia o verdadeiro devoto do Rosário, meditando a vida e vivendo os anos de Cristo, e meditando a vida e vivendo os anos da Virgem Maria? Cristo instituiu o Santíssimo Sacramento para que nós vivêssemos pela sua vida, assim como ele vive pela do Padre; e a Virgem Maria instituiu o Rosário como outro Sacramento, para que nós vivêssemos a vida de seu Filho e mais a sua. E assim como Cristo no Sacramento, não contente com viver em nós por graça, quis também viver em nós por memória - In mei memoriam facietis- assim a Virgem Santíssima no Rosário se não contentou somente com que rezássemos as orações, senão que meditássemos os mistérios, para que por meio da meditação da vida de seu Filho e sua, vivessem ambos em nós, e nós em ambos por memória e graça"; cf. Padre Antônio Vieira (1965c).

74. Como se lê no Capítulo IV do mesmo sermão: "os mesmos mistérios da vida de Cristo e sua Santíssima Mãe, que o Rosário medita e celebra todos os dias, a Igreja universal os distribui somente por certos dias do ano, devołos, nem à cortesia ou fé dos que o não fossem, senão que a mesma Senhora, como autora e fundadora de um instituto tão propriamente seu, a tomou por sua conta. E em quem mostrou a providência soberana da Mãe de Deus a verdade e eficácia destes poderosos efeitos do seu Rosário? É a prova tão universal e tão particular, que só poderá ser sua ${ }^{70}$.

Há, na Espanha, em época próxima à do livro do jesuíta Francisco Aguado, uma pintura pertencente à Irmandade do Sacrário, da Catedral de Sevilha, de autoria de Herrera, o Moço, inovadora na composição, com o título de Triunfo da Eucaristia (1 656), que associa a Virgem com este sumo sacramento do catolicismo. Por outro lado, nas custódias barrocas que a autora examina, a coroa de raios (sol) que envolve o disco ou luneta apresenta, nas pontas dos raios, 15 estrelas, que representam os (na época) 15 mistérios da fé cristã: o Rosário da Virgem. No conceito da época, o Rosário da Virgem é, também, o Rosário de Cristo.

Duas cabeças. Ambos, Rei e Rainha, vão afirmar a "verdadeira fé", fazer vencer a lgreja. Tal como a Cristo - que "porá debaixo dos pés todos os seus inimigos, e todos o conhecerão e adorarão, e que ele só terá nome de Deus e Senhor em todo o Mundo" -, também à Virgem Maria

canta a lgreja o elogio da vitória e extinção de todas as heresias, porque com sua poderosa intercessão extinguiu muitas, e com ela há de extinguir as demais, até que inteiramente quebre a cabeça do Dragão infernal (que como hidra se tem multiplicado em tantas cabeças) e completamente se verifique a universalidade do dito elogio - Gaude, Maria Virgo, cunctas haereses sola inter emisti in universo mundo... 71

E ainda o celebrado padre Antônio Vieira (1608-1697) assim argumenta, no Capítulo VII do sermão $\bigcirc$ Santíssimo Sacramento Exposto, o de número VIII na edição que preparou sob o título de Maria Rosa Mística, cujo tema central é a comparação da "devoção do Rosário com a de toda a lgreja": 72

A Virgem Maria instituiu o Rosário como outro Sacramento, para que nós vivêssemos a vida de seu Filho e mais a sua. [...]

Que muito é que um dia do Rosário seja tão grande como um ano de lgreja, se é tão capaz e tão imenso, que abraça todos os trinta e três anos da vida de Cristo, e todos os sessenta e três da vida de sua Mãe? ${ }^{73}$

Rosário é síntese: une os mistérios do Cristo e da Virgem - a lgreja Católica. Nesse culto do Rosário, comparado a um sacramento, a lgreja Universal (as pessoas, a multidão de fiéis, como diz Vieiral torna-se concreta a cada indivíduo. Os mesmos mistérios da vida da Virgem e do Cristo que, em alguns dias do ano, são celebrados publicamente com pompa e majestade pela lgreja Universal, são celebrados de modo privado todos os dias do ano na oração do Rosário, na sua roda, nas suas contas ${ }^{74}$.

Se, na visão de Vieira, nas celebrações da lgreja Universal o Santíssimo Sacramento da Eucaristia, o "soberano mistério", repete a crucificação (sacrifício), a redenção da Humanidade como um sacramento, isto é, continuadamente, o 
Rosário, por sua vez, o celebra diariamente. É outro sacramento, igual e tão importante quanto o da Eucaristia.

Ao associarem dois momentos espirituais - a Encarnação e a Ressurreição - mediados por um momento carnal, a Paixão (Sangue de Cristo, Remissão), os mistérios do Rosário representam o próprio dogma da lgreja. Já a Eucaristia, o denominado Santíssimo Sacramento da Eucaristia, mistério maior da fé católica, consubstancia tudo isso. Por isso, na doutrina escatológico-messiânica do Quinto Império desenvolvida pelo jesuíta Antônio Vieira, a Eucaristia, tal como a Virgem do Rosário, a Mãe de Deus e dos Homens, a Virgem Santíssima propriamente dita, vão ter um papel central.

dogma da lgreja, portanto, se assenta numa representação dual, de complementaridade entre o Cristo e a Virgem, mediados pelo Espírito Santo. Conforme a doutrina, a carnalidade do Cristo, condição da salvação universal, está associada á Virgem, tanto quanto nela se liga a Deus a alta espiritualidade que a condição humana pode alcançar - ambos subiram de corpo e alma aos céus. Ele, o Redentor, ela a Redentora - o Filho e a Mãe, Rei e Rainha. É a união mística com o Cristo.

Cristo é águia, a Virgem é águia, dizem os exegetas. Cristo, em sua Ascensão; a Virgem, em sua Assunção. No Sermon Veinte de la Admirable Ascension del Señor e no Sermon Treinta y Cinco de la Assuncion de Maria Santissima, predicados pelo padre trinitário Juan de Jesús María, com edição impressa no ano de 1718, Frei Juan discorre sobre a "Ascensão aos Céus" de Cristo e a "Assunção aos Céus" de Maria.

Cristo, diz ele, pôde subir "porque voló esta Aguila Divina sobre toda imaginación Angelica y humana". E a Virgem Mãe, "A María se le dan alas de Aguila, quando buela á la Celestial Esfera"75.

E Frei Juan de Jesús Maria pergunta que asas são essas de Maria:

Y qué alas venían á ser estas? [...] estas alas son dos vidas: Due ale sunt due vita. La una es la vida del alma, y la outra es la vida del cuerpo. Luego esta mujer grande gozava en el Cielo de duplicada vida: de la vida espiritual, y de la vida corporale Así es con razón [...] merece el privilegio de estar en el Cielo, en alma, y cuerpo.

Diz também que Cristo subiu "como Hombre ao Cielo":

Sube Christo, como Aguila Divina, triunfante à los Cíelos; y apenas sube, quando le dá su mano derecha el Padre: Sedet à destris Dei. No ay duda, que el Padre dio su mano derecha al Hijo, en quanto Hombre, porque se la dio, en quanto subio y Christo no subió al Cielo, en quanto Dios, sino en quanto Hombre ${ }^{76}$.

Os textos apresentam o Cristo-Águia com duas naturezas. E também a Virgem-Águia. Não é outra coisa o que diz o padre dominicano Frei Juan de Mata, numa prédica publicada em 1631: "Dos alas de Aguila, Christo y Maria hijo y madre al Aguila se compara en la antiguedad [...]. Solo considero, que aplicando e consagrando um dia a cada um. Um dia ao mistério da Encarnação, outros à Visitação, outro ao Nascimento, outro a Presentação no Templo, outros, e uma semana inteira, aos mistérios da Paixão, outro à Ressurreição, outro à Ascensão, outro à vinda do Espírito Santo, e outro, finalmente, à Assunção e Coroação da Virgem, Senhora nossa, que são todos os do Rosário"; cf. Padre Antônio Vieira (1965c).

75. Cf. Frei Juan de Jesús María (1718, p. 209 e 377).

76. Idem, p. 155 e 129. 
77. Cf. Juan de Mata (1631, p. 199).

78. A imagem pode ser vista na página sobre a Escuela cuzqueña de pintura, do portal Wikipedia.

79. Cf. Beatriz Mariscal Hay (2004, p. 93-102).

80. Idem. honro de suerte Dios a Maria, que la hizo Aguila de la Iglesia, con cuyas alas, protecion y amparo, quedose defendida"77.

As duas águias, simbolizando essa união, essa aliança, aparecem numa tela do espanhol Luis Riaño ${ }^{78}$, pintada para uma igreja de Cuzco, no Peru, em meados do século XVIII. O tema é o da Anunciação, que mostra o momento bíblico em que o Arcanjo Gabriel anuncia a encarnação do Verbo Divino no ventre de Maria. A imagem representa o estabelecimento do vínculo entre o Espírito Santo e a Humanidade. O atril, onde está pousado um livro - a "sagrada escritura" -, tem como pilares/suporte uma águia de cada lado.

Essa comunhão alma-corpo caracteriza a Humanidade numa Nova Aliança. A dupla natureza de carne e espírito (Encarnação-Ressureição) representa - Sumo Sacramento, a Eucaristia. A escrita da época (século XVII), casando alma e corpo, acentua essa dupla natureza que une o macro e o microcosmos.

Mais recuado (antes do último terço do século XVI) é o aparecimento da representação nítida dessa dualidade do sagrado com a figura da águia bicéfala. A ocorrência é no Novo Mundo. Ela ocorre num auto sacramental escrito para ser apresentado na Cidade do México, na Festa do Corpo de Deus. O auto, denominado Coloquios espirituales y sacramentales (ca. 1574), é de autoria de Fernán González de Eslava (1534-1603?), espanhol residente na capital da Nova Espanha.

Essa obra manuscrita foi publicada, em 1610, no México, pelo religioso agostinho frei Fernando Vello de Bustamante, amigo pessoal do autor. Nela, Eslava associa às forças divinas as sete fortalezas erguidas pelo vice-rei do México na guerra contra os chichimecas. No desenvolvimento do tema doutrinário, as fortalezas representam os sete sacramentos da lgreja. $\bigcirc$ sacramento do matrimônio, segundo ele, deve ter duas caras, "deve estar composto simultaneamente pela Justiça e a Misericórdia", e para isso utiliza a figura da águia bicéfala ${ }^{79}$. No texto, as explicações são as seguintes:

La puerta del Matrimonio, nuestro segundo ejemplo, debía llevar el siguiente emblema:

Puerta del Sacramento del Matrimonio, donde está por guarda la lusticia que es la ygualdad que se deve guardar entre los casados. En esta puerta está una águila con dos cabezas, que significa las dos naturalezas de Christo en un supuesto, y el Matrimonio que contrajo con nuestra naturaleza. Tenía esta Hieroglíphyca la letra siguiente:

Christo es Águila de Imperio,

do se muestra manifiesto

Dios y hombre, en un supuesto,

y el Sacramento y mysterio

del Matrimonio en aquesto ${ }^{80}$.

E o recuo no tempo é maior ainda no âmbito de uma leitura alquímica do texto sagrado.

O Livro da Santa Trindade (Buch der heiligen Dreifältigkeit) - que, ao tempo do Concílio de Constança (1414-1418), foi publicado na Alemanha por um desconhecido frei Ulmannus, tendo alcançado então grande popularidade - é 
"a publicação que mais utilizou uma interpretação alquímica e cósmica da Bíblia". Segundo escreve Joan Feliu Franch, historiador espanhol da Universitat Jaume I, em Valencia, esse livro "pretendia ser não apenas um tratado alquímico com base na historia sagrada, mas um mecanismo de autêntica renovação da Fé" ${ }^{\prime 1}$. A alquimia "era concebida como uma parte da mística, cujo fim era a união do homem com Deus" 82 .

No saber alquímico do Renascimento, conforme se vê no Livro da Santa Trindade (1414-1418), a taça, o Cálice Sagrado da Santa Comunhão simbolizava a transmutação alma-corpo. Aí aparece a associação do Cristo à águia bicéfala, na união com a Virgem: Encarnação-Ressureição. No livro, era descrito um Cristo crucificado sem cruz ou, então, com a cruz "escondida ou oculta, coroada por uma águia de duas cabeças, aparecendo por detrás sete feridas ou padecimentos com uma águia e uma coroa" ${ }^{83}$. Um manuscrito do século XVI, da Biblioteca Vadiana de Saint Gallen (Suíça) repetia a simbologia do Livro da Santa Trindade, agora apresentando um "Cristo vestido de águia bicéfala (símbolo alquímico do mercúrio) que nascia da Virgem, de novo como matéria prima" 84 .

Duas águias unidas, duas cabeças, duas coroas. $\bigcirc$ Império aqui, não é o dos homens, mas o da lgreja: a águia bicéfala das custódias, portanto, não significa uma alusão à dinastia (Habsburgo) que defende o dogma da religião: a águia de duas cabeças coroadas é o próprio dogma da lgreja - é a Virgem com o seu filho, a Virgem Mãe de Deus. Nas concepções do tempo, Maria Santíssima é a Mansão do Senhor, o Primeiro Sacrário, o Novo Tabernáculo, a Arca da Aliança. A ela devem os homens a luz da graça divina, a proteção. A comunhão humano-divino representada na Virgem e no Cristo se repete pela via sacramental, a do ato da Eucaristia, o Sumo Sacramento ${ }^{85}$.

Já na mariologia do franciscano John Duns Scott (1265-1308), o Doutor Sutil, pode ser encontrada a ideia de que "todo o Reino de Cristo é também reino de Maria, sua Mãe [...] e assim como pela vontade de Deus todos recebem tudo através de Maria em mediação descendente, assim também tudo o que de todos se dirige a Deus vai através de Maria, exercendo ela a mediação ascendente"86. A Virgem é a suprema mediadora.

Religião salvífica, o Catolicismo, os seus Mistérios são os da Redenção do Homem. A águia de duas cabeças é o Rosário. Nas palavras do padre Antônio Vieira, seu maior cultor:

Toda a matéria do Rosário não é outra que o mesmo Verbo encarnado, não em uma só acção, ou mistério, senão em todos os de sua vida, morte e ressurreição. A ideia, com que a Virgem os concebeu e compreendeu todos, e os ordenou e dispôs na mente, foi a conceição: e a luz por tantos séculos escondida, com que finalmente os manifestou ao mundo para tanto bem do mesmo mundo, foi o felicíssimo parto do Rosário ${ }^{87}$.

No último terço do século XV, diante de uma medievalidade em crise, a conturbada Igreja Romana encontrou, na devoção ao Rosário, uma forma de congregar junto a ela cristãos de qualquer cor, condição e estado, e de ser glorificada em seu poder - os Dominicanos, defensores, juízes da fé, foram seus
81. Cf. Joan Feliu Franch (2005, p. 120).

82. Idem, p. 118.

83. Idem, p. 128.

84. Idem, p. 131.

85. Ver Frei Nicolau Dias (1982); e também Padre Antônio Vieira (1957).

86. John Duns Scott apud Constantino Koser (1972, p. 71-87); grifo meu.

87. Padre António Vieira apud Carlos Alberto de Seixas Maduro (1998, p. 122123). 
88. Cf. Jacques Le Goff (1982, p. 165).

89. Cf. Jacques Heers (1971). A obra desse professor jubilado da Paris IV, Sorbonne (Nanterre), especialista no comércio no Mediterrâneo nos séculos XIV e XV (que é $o$ assunto de sua tese de doutorado, defendida em 1958), é importante para quem queira avaliar o desenvolvimento dos reinos muçulmanos $\mathrm{e}$ cristãos, interpenetrando Oriente e o Ocidente. Em relação a esse tema, reiterado em sua vida profissional, deve-se assinalar a recente contribuição de Jacques Heers ao publicar o estudo globalizante em que analisa as relações turco-muçulmanas e europeias, no geral conflituosas, no Mediterrâneo ocidental (Magreb). cf. Jacques Heers (2001). Já as relações entre Espanha e o Magreb (Alger, Tunis, Orã), com ênfase nos mourisco e nos mudéjares migrados da Andaluzia para lá, tem sido estudo, entre outros, pelos professores Míkel de Epalza (falecido em 2008) e Luis Bernabé Pons, da Universidade de Alicante; ver Míkel de Epalza (1994; 2001); e Luis Bernabé Pons (2009). Referencio ainda o estudo de Hossain Bouzineb (1998); e o livro de Miguel Ángel de Bunes (2004).

90. Conforme se lê no verbete Imperio Otomano, do Diccionario de Relaciones Internacionales y Política, o "Império otomano foi forjado entre os séculos XIV e XVI pelos turcos otomanos procedentes da Ásia centro-ocidental e instalados na Anatólia". O "domínio dos muçulmanos turcos" alcançou, em meados do século XVI, "uma extensão de 10 milhões de $\mathrm{km}^{2}$, repartidos entre Europa, Ásia e África". Eles "encarnaram durante séculos a ideia dialética do 'outro', oposto e antagônico à Europa cristã, e em cujos limites tinha início o Oriente muçulmano"; cf. Juan Carlos Pereira (2008, p. 499). propagadores. A ideia transmitida é de que o Rosário, a Virgem Mãe estende o seu benefício a tudo e a todos, vence o Mal no mundo. A arte dos anos finais do Quatrocentos em diante já expressa essa noção: o poder da lgreja está na Virgem, que é identificada com a própria lgreja.

Ao iniciar o século XVI, estando Maximiliano de Habsburgo (14931519) - avô e antecessor de Carlos V - na condição de Imperador do Sacro Império e Rei dos Romanos, há um revigoramento da tríade Igreja-RomanidadeImpério. Uma encomenda imperial, feita a Albrecht Dürer em 1506, expressa a ideia de união entre o Papa e o Imperador, submissos à Virgem, que representa a lgreja Universal. Tal pintura, intitulada A festa do Rosário, mostra bem as expectativas políticas - um projeto político, do mundo germânico e do papado - de aumentar a ascendência sobre a Europa, para superar o poder crescente do reino de França: o Sacerdócio e o Império (na pessoa do Papa Júlio II e do Imperador), ajoelhados aos pés da Virgem, sendo o Papa ungido com a coroa de rosas, pelo Menino Jesus; e o Imperador, pela própria Virgem.

A Virgem do Rosário teve sua devoção associada às vitórias contra o Mal, à defesa das forças armadas dos Estados da cristandade católica contra aqueles considerados hereges e infiéis à sua doutrina. No que se refere aos muçulmanos, sobretudo, contra eles tremularam as bandeiras da Senhora do Rosário - combater os infiéis com a força armada era incumbência e direito do Império e dos aliados do Papa. Na ldade Média, a grande unanimidade entre os cristãos sempre foi considerar o mundo muçulmano, relativamente próximo, como sua antítese total. Os muçulmanos eram propriamente o Anticristo, epíteto que teve enorme sucesso na Cristandade Medieval (contra os inimigos, era um instrumento publicitário eficaz) e adentrou pelos séculos $X V$ e XVI88.

Era senso comum que a Cristandade deveria se estender por todo o mundo, incluindo as imensas terras do islã. Trata-se de um antagonismo fundamental que, por outro lado, sempre representou um antagonismo baseado no domínio de rotas comerciais, territórios e riquezas a serem exploradas e povos a submeter. Um bom panorama a esse respeito é dado pelo clássico estudo de Jacques Heers sobre Gênova lque juntamente com Veneza alcançou proeminência comercial no século XV), o Mediterrâneo e o capital comercial. Recentemente, Heers publicou um estudo global sobre as relações entre o Islão e a Europa, com o foco na região franco-ibérica e no Magreb, a África do Norte, ou seja, o Mediterrâneo ocidental ${ }^{89}$. Portanto, o inimigo global - que pode invadir e/ou perturbar o avanço da máquina do mundo ocidental cristão em sua expansão, em seu enriquecimento, sua supremacia, e afirmação de seus valores - teve um rosto: o Islã. O maometano era também, na época de Vieira, tratado como "turco", pois os muçulmanos turcos da Anatólia (Oriente Próximo) expandiram seu império (Império Otomano) até a África Ocidental, fronteando Espanha e Portugal no Mediterrâneo90.

Essa associação de ideias - a Virgem significando a lgreja Universal, à qual todos devem se submeter - já está presente na tela que Ticiano pintou em 1528 para a igreja franciscana de Santa Maria Gloriosa dei Frari, em Veneza. Em 1571, a vitória da armada cristã contra a turca, na grande batalha naval de 
Lepanto (Grécia), é atribuída à aparição e proteção da Senhora do Rosário aos fiéis. Na afirmação do seu território, em épocas remotas, outros Estados do catolicismo romano reivindicam sua presença: a Virgem está presente na tela $A$ batalha de Jerez, uma cena histórica do século XIII, pintada por Zurbarán em 163891, como também na Conquista de Lisboa aos mouros, episódio datado do século XII (1 147), obra executada pelo pintor português José de Avelar Rebelo, entre 1647-1650.

Mas para a Virgem, a Senhora do Rosário e da Vitória, representando a junção do céu e da terra, aparecer simbolizada na águia bicéfala, ou seja, trazendo para si um símbolo que a política temporal vinha retendo em suas armas há séculos (via Sacro-Império Romano), temos de esperar a conjuntura do último terço do Seiscentos europeu. De fato, de meados do século XVII em diante, há um revigoramento significativo do culto ao Rosário, alavancado pela ação da Companhia de Jesus.

Em 1689, a decoração em gesso do camarim-retábulo do Santuário de Nossa Senhora da Vitória, em Málaga, também rememora uma batalha - a da conquista dessa cidade aos árabes em 1487, pelos Reis Católicos - e, entre os símbolos em relevo associados à Virgem Maria, sobressai o da águia bicéfala encimada pela coroa aberta, a da Rainha do Céu. É uma afirmação do reino de Espanha, onde governa a Casa dos Áustrias, que vivia o seu ocaso, mas acabava de religar-se por casamento ao Sacro Império (Filipe IV e Mariana de Áustria); é, sobretudo, uma adesão à ideia transnacional de que é a Virgem (a lgreja) que deve ser afirmada e defendida, de que é ela que representa o Império de Cristo na Terra ${ }^{92}$. $\bigcirc$ mesmo símbolo está presente no belo frontal bordado (fins do século XVII, inícios do século XVIIII) do altar da capela de Nossa Senhora da Vitória e Almas, na vila de Luso, município de Mealhada, em Portugal.

Contemporâneas à decoração existente em Málaga, há duas obras que indicam a novidade dessa águia referida como a Senhora do Rosário: dois folhetos com relatos de acontecimentos da guerra total dos cristãos aos infiéis. Confrontando com os cristãos (no domínio territorial e no giro dos negócios no Mediterrâneo), o contínuo avanço do império otomano chega a Viena, sede do Sacro Império Romano. No último quarto do século XVII, a ameaça sobre a ltália e sobre o Papado, caso fosse derrotado, o Imperador Leopoldo I conclama todos os monarcas a formarem uma Liga Sagrada para levar o Turco (o Islã) à derrota e cada vez mais para longe.

Na conclamação é evocado o patrocínio da Cristandade, o que significa lutar pela lgreja, pela Fé católica, e em nome da Mãe dos Homens, acreditando que ela os protege e os levará à vitória contra os infiéis. Se na célebre batalha de Lepanto contra o mesmo Turco, um século antes, a Senhora do Rosário foi a grande vencedora os católicos e apostólicos romanos acreditam que ela novamente não thes faltará. E se a Hungria de Santo Estevão não desaparecera de todo, isso seria devido à mesma Senhora.

Papa Inocêncio XI pede que todos os príncipes cristãos - católicos, ortodoxos e protestantes - unam-se sob as ordens de Leopoldo I, o Imperador do Sacro Império Romano da Alemanha, sob o brasão da águia bicéfala: Viena não
91. Atualmente no Metropolitan Museum of Art, em Nova York.

92. Depois da vitória naval alcançada em Lepanto (1571) pelas forças cristãs contra as otomanas, o Papa Pio $\mathrm{V}$ ordenou que se festejasse todo o dia 7 de outubro a festa de Santa Maria da Vitória ou Nossa Senhora da Vitória, a quem se atribuiu o sucesso das armas da Cristandade. Por ordem de Gregório XIII, em 1573, a festa da vitória contra os "infiéis" seria realizada em todo o mundo cristão onde houvesse um altar ou uma capela sob a invocação da Senhora do Rosário. Em 1671, a rainha Mariana d'Áustria, de Espanha, alcançou do Papa Clemente $\mathrm{X}$ que a festa fosse estendida a toda a Espanha, sem restrições, em qualquer igreja. 
93. Em relação ao cerco de Viena, o historiador francês Victor Tapié comenta sobre a conclamação à luta: "Auf, auf ibr, Christen! De pé, de pé, cristãos! É ainda a voz de Abraão a Santa Clara, que soa a voz de reunir"; Cf. Victor Tapié (1974, p. 39).

94. Ver Sebastian de Armendariz (1686).

95. Ver Sebastian de Armendariz (1687); grifo meu. É interessante notar que esse livreiro propagandista do Império de Cristo, num país como a Espanha, onde Carlos II era um Habsburgo que não deixaria herdeiros, mostra uma tendência para os Áustrias alemães quando proclama a Virgem "protetora do Cristianismo contra os otomanos, e sensivelmente inclinada aos Austríacos".

96. Há, nesses anos finais do século XVII, outras duas batalhas importantes no confronto com as armas otomanas: a libertação da cidades húngaras de Neuheufel, considerada a "Chave da Cristandade", em 1685; e a de Buda, em 1686, ambas pelos exércitos sob comando do Sacro-Império.

97. Ver padre-mestre Francisco de Figueroa (1642). O Padre Figueroa era Definidor da Província peruana dos Predicadores (Ordem de São Domingos). deve ser tomada. Em 1683, o exército de cristãos que então se forma assemelhase aos dos Cruzados.

Pequenos folhetos, os denominados relatos de acontecimentos, circulavam por toda a parte, em várias línguas, trazendo notícias das guerras nas fronteiras orientais da Cristandade, parecendo que ali se decidia a sua sorte. Se o cerco de Viena em 1683 assustara toda a gente, a vitória e expulsão dos otomanos pelo Imperador alemão despertaram sonhos cruzadísticos e a fé dos cristãos ${ }^{93}$.

Dois desses folhetos, de caráter filojesuítico, trazem à tona o emblema da águia bicéfala recriado, ressignificado, como explicado adiante. Ambos foram editados em Madri no ano de 1687. O primeiro deles é um relato de sucessos das "armas Cesareas desde el Año de 1683 hasta todo el de 86", sobre o Turco, editado em Madri no ano de 168794, e traz no seu frontispício uma dedicatória a São Francisco Xavier, espanhol de Navarra, chamado de Apóstolo do Oriente, dando a ele o papel de "protetor das hostes cristãs e especialmente das Austríacas", sob o comando do Imperador, "Catolicíssimo César".

O outro folheto, editado pelo mesmo livreiro, tem maior importância para o que está sendo analisado: descreve os lugares que ainda estavam de posse do Turco na Hungria e na Eslavônia e, na dedicatória, socorre-se na Virgem (e não apenas na intermediação do santo jesuíta), a Virgem que estaria premiando os exércitos imperiais, a Liga Sagrada contra o Turco. Aqui, a revelação: essa "que antes em vários tempos deu muitas Palmas aos Exércitos Cristãos" é também a "águia misteriosa do Apocalipse e também do Império Cristão"! !95

Em 1686, a Hungria, tida por filha dileta da Virgem Santíssima, tem sua capital reconquistada. Buda estava nas mãos dos otomanos desde 1526. Em todas as igrejas da cristandade, há orações. E os porta-vozes do Sacro Império consideram Viena, sede do império da águia, a nova Roma. Em 1685, a grande conquista fora a retomada da fortificação de Neuheufel, considerada a "Chave da Cristandade".

Nesse momento, na massa de pequenas estampas populares, avulsas - que circulavam pela Europa da época representando prodígios, batalhas e santos -, é possível deparar com uma imagem - ainda fazendo publicidade da facção germânica (e papal) imperial - que, tudo indica, propaga a toda a gente ○ "milagre" da libertação de Viena, na batalha de Kalhenberg (Figura 9196. Mas a águia bicéfala que paira entre nuvens e anjos no meio do céu (sobre uma meialua), até por isso mesmo, significa inequivocamente o poder soberano da Virgem, "vestida de sol", na sua unidade, pois, o "reynado, e imperio de MARIA divina, es indiviso con el de su hijo"97.

A imagem é pequena $(10,5 \mathrm{~cm} \times 6,5 \mathrm{~cm})$ e não traz assinatura. A batalha - a cidade sitiada ao fundo e as tropas cristãs avançando sobre ela - está na zona inferior esquerda da estampa. Em primeiro plano, à direita, sobre uma elevação do terreno, estão o Papa Inocêncio Xl e o Imperador Leopoldo, ajoelhados, tendo depositadas no solo a coroa imperial e a cruz papal, em sinal de humildade e reverência (o papa conserva a tiara pontifical). No alto, no centro da estampa, sobre tudo e todos, envolta em glória, uma águia bicéfala pousada 


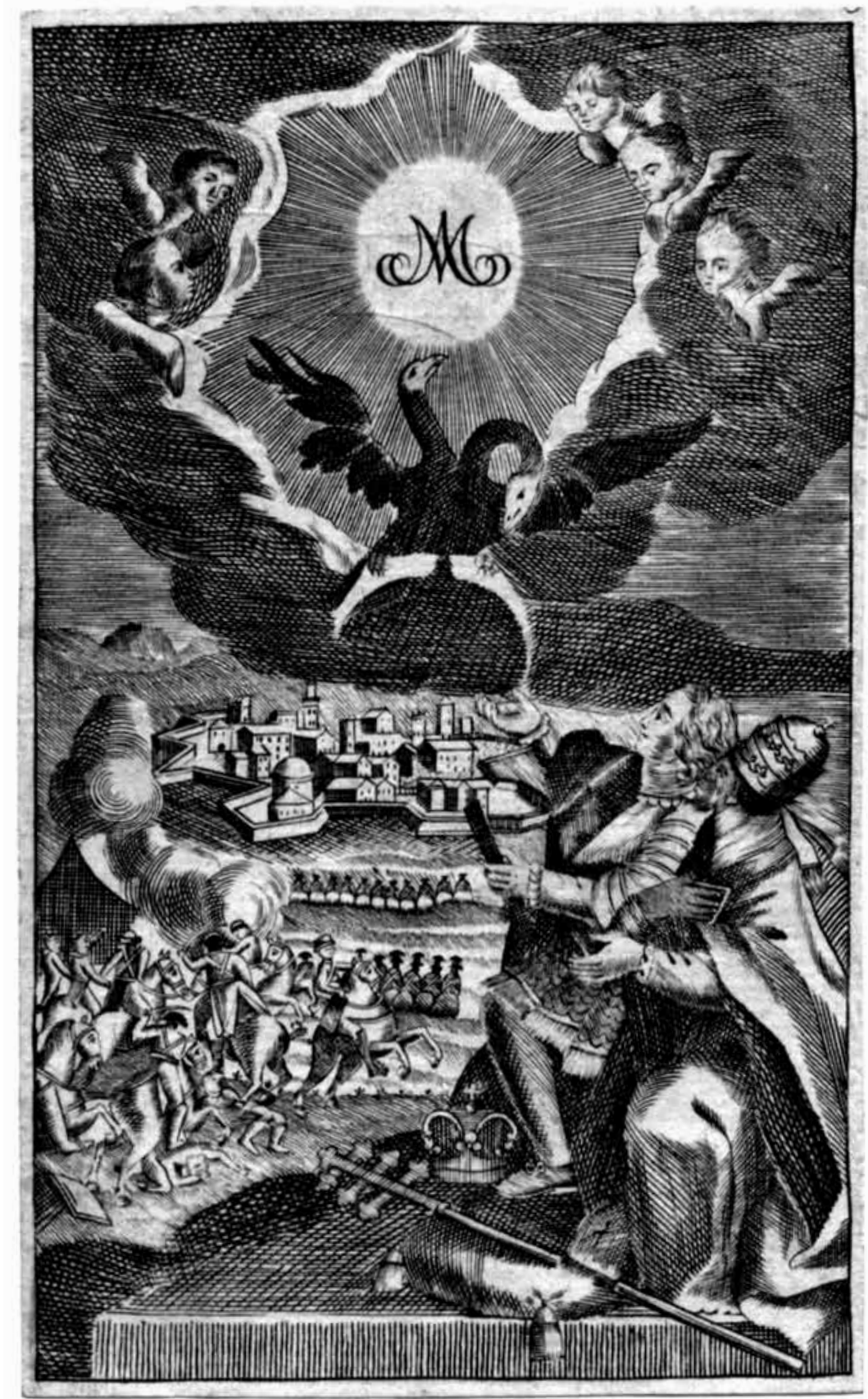

Figura 9 - Estampa que celebra possivelmente a expulsão dos turcos no cerco de Viena, pelas forças do exército imperial (Liga Sagrada), em 1683. A Virgem do Rosário toma a forma da águia bicéfala: "la aguila misteriosa del Apocalypsis, y tambien de lo Imperio Christiano"... O monograma da Virgem - AM (Ave Maria) - sobre a águia é eloquente. $O$ dia 12 de setembro, data da Batalha de Kalhenberg, que libertou Viena, é dedicado ao Nome de Maria, por decisão de Inocêncio XI. Coleção Particular. Fotografia de Jaelson Bitran Trindade. 
98. Ver Jaelson Bitran Trindade (2004).

99. No Museu paroquial bejense, oriundas do mosteiro local da Conceição, há cinco águias bicéfalas esculpidas $\mathrm{e}$ douradas (c. de $46 \mathrm{~cm} \times 37$ $\mathrm{cm}$ ), com argola de suspensão na parte traseira e trazendo no peito a cruz de Santiago. As ordens militares, como a de Santiago, tiveram enorme importância na defesa das praças cristãs conquistadas aos mouros. O último painel da série que compõe o célebre Retábulo da Vida e da Ordem de Santiago, de meados do XVI (ca. 1520 1525), hoje no Museu de Arte Antiga (Museu das Janelas Verdes), em Lisboa, mostra o Mestre da Ordem invocando a Virgem (que aparece com o Menino) em Tentúdia, no enfrentamento com os mouros.

100. Cf. Flávio Gonçalves (1986, p. 242)

101. Idem, p. 229.

102. Cf. Pedro Dias (1998, p. 335). nos cornos da lua e tendo por fundo o Sol radioso, com o monograma da Virgem Maria (Ave Maria - AM). Uma das cabeças se volta para o cév; e a outra, para a terra, para os homens. $\bigcirc$ poder do Papa e do Imperador submetem-se a um poder maior sobre o Cév e a Terra: o Sol e a Lua, o Cristo e a Virgem.

momento da disseminação do símbolo foi concomitante ao do reforço da devoção na Rainha dos Homens, um momento de glorificação da fé católica: a Igreja Triunfante, Roma Triunfante. Desde a década de 1670, avançando até os primeiros anos do Setecentos, a devoção ao Rosário teve um nítido crescimento em Portugal, com a fatura de novos retábulos à Virgem, e não só retábulos, mas ciclos pictóricos alusivos à Senhora envolvendo retábulos: em Portugal sobressaem as telas executadas por Bento Coelho da Silveira e Antônio de Oliveira Bernardes. E não haveria como dissociar desse crescendo os 15 medalhões com os Mistérios do Rosário, que Valdés Leal pintou na igreja de Santo André, de Sevilha, na década de 1660.

Desde o último terço do século XVII até o primeiro quartel do seguinte, para receber a "Mãe de Deus", são fabricados no mundo português numerosos retábulos de altares, cuja forma em arcos concêntricos faz referência ao portal românico de épocas anteriores (séculos XII e XIII), naqueles tempos denominado "Porta do Céu". Na tribuna formada pelas colunas que se arrematam em arcos, fica um trono escalonado (escada celeste) onde é exposto, no cimo, o Santíssimo Sacramento - a historiografia da arte denomina-os talha de "estilo barroco nacional português" Graça, em Setúbal, de Santa Maria e do Sagrado Coração de Jesus, em Beja99, e da matriz de Borba, todas no Alentejo; e, tal como nesta última, são já do século XVIII os retábulos da igreja de São Francisco, no Porto ${ }^{100}$, e o da matriz de Caminha, na região do Minho. Na Estremadura portuguesa, os dois altares de talha do Convento das Bernardas, em Almoster, Santarém, têm no remate águias bicéfalas, como me informa Vítor Serrão, historiador de arte português.

Particular atenção, nesse sentido, merece a representação da Árvore de Jessé ou Linhagem da Virgem do Rosário (numa concepção que a faz descender dos reis do Antigo Testamento - sendo eles os antepassados também de Jesus, a genealogia do Cristo transforma-se na genealogia da Virgem), que é o assunto de muitos dos altares acima citados. Seu interesse iconográfico e catequético já foi objeto de um pequeno estudo de Flávio Gonçalves, historiador português de arte.

A Árvore de Jessé também aparece bordada em colcha indo-portuguesa do século XVII101. As colchas indo-portuguesas - origem das famosas colchas de Castelo Branco, em Portugal - podem ser vistas em diversos museus europeus. Em Portugal, há exemplares em Lisboa (Museu Nacional de Arte Antiga), Coimbra (Machado de Castro), Porto (Guerra Junqueiro), entre outros, além de coleções particulares ou ainda nas igrejas, como o goderim (proveniente de Guzerate, India), pertencente à Santa Casa da Misericórdia de Setúbal. Há exemplares em Florença, no Museu Bargello, no Victoria and Albert Museum, em Londres e no Museu Nacional de Artes decorativas de Madri 102.

Frontais de altares bordados em tecido também levavam a mensagem da águia. Já foi citado o frontal do altar de Nossa Senhora da Vitória e Almas, 
na vila de Luso (município de Mealhada), Distrito de Aveiro e existe outro, dos jesuítas, que pertenceu ao Noviciado da Cotovia, em Lisboa (Figura 10) $1{ }^{03}$. Por vezes, o bordado é transposto para a arte da azulejaria, como se vê na capela de Nossa Senhora do Amparo ${ }^{104}$, em Albergaria-a-Velha, datada do século XVII, e em diversos frontais expostos hoje em dia no Museu Nacional do Azulejo, em Lisboa. No Museu Diocesano de Vic (Vich), província de Barcelona, está um frontal contemporâneo aos anteriores, um esplêndido trabalho de arte em couro repuxado, onde a figura de San Feliu mártir (São Filipe), pintada a óleo, é ladeada por duas grandes águias bicéfalas coroadas ${ }^{105}$.

São da mesma "família" a representação de duas águias e um coração entre elas, sob uma coroa; ou, ainda, de dois corações sob uma coroa ladeados por duas águias. Essas podem ser vistas em colchas ou decorando uma de salva de prata, como se pode ver na coleção do Museu Nacional de Arte Antiga (Museu das Janelas Verdes), em Lisboa. Na ourivesaria, além dos ostensórios (ou custódias) do Santíssimo Sacramento, também se fizeram medalhões com a forma da águia bicéfala coroada, tendo centro a Virgem Santíssima com os atributos da sua litania (ladainha).

A águia bicéfala aparece também dando forma a um relicário de ouro do século XVII, das monjas agostinianas do Convento da Encarnación, em Sevilha,
103. Idem, p. 435.

104. Traz no centro um rótulo com a Virgem e o Menino, envolto em rica decoração à maneira dos bordados indianos, com hastes florais e pavões, motivos também associados tradicionalmente à Virgem.

105. Ver Juan Subias Galter (1948, p. 268).

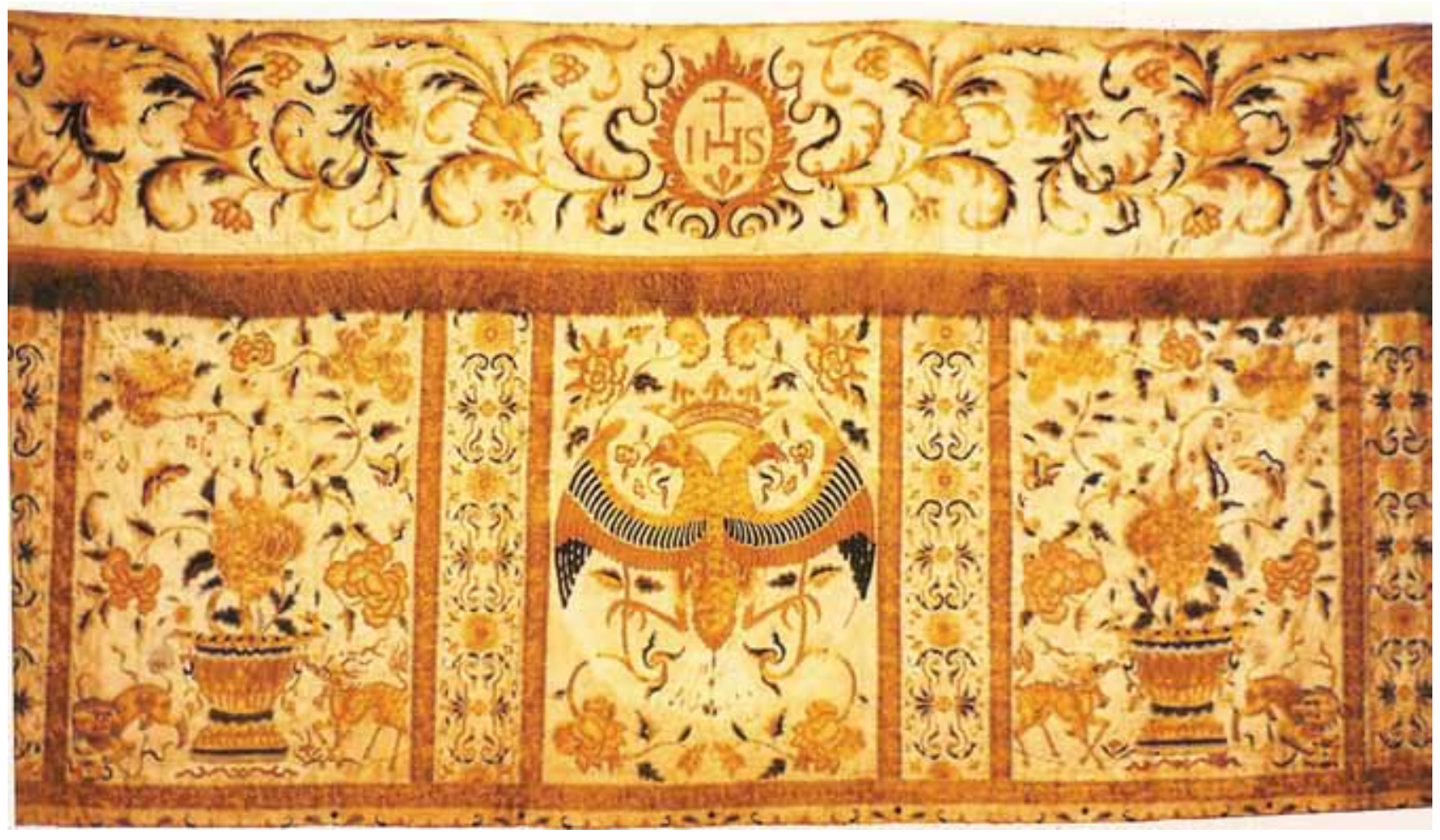

Figura 10 - Frontal de altar, em seda chinesa e bordado a fio de ouro, que pertenceu ao Noviciado da Cotovia, estabelecimento da Companhia de Jesus em Lisboa. Museu de Ciência da Universidade de Lisboa. Fotografia do historiador de arte Pedro Dias, da Universidade de Coimbra (cortesia). 
106. "Desgraciadamente, como ha sido habitual en cierta época de nuestro país ha sufrido el expolio de parte de su patrimonio artístico llamando la atención la desaparición de un bonito sagrario de madera con forma de águila bicéfala y decorado en oro"; cf. Ayuntamiento de Valtajeros.

107. Exemplos desses objetos podem ser vistos em alguns dos Museus que percorri, tais como o Museo de Arte Hispanoamericano Isaac Fernádez Blanco, em Buenos Aires, e Museu de Plata, Argentina; Museo de América y Museu de Artes Decorativos, em Madri; Museu de Évora, em Portugal; Museu Paulista, da Universidade de São Paulo.

108. Cf. Lúcio Costa (1978, p. 97-98).

109. O lavabo tem sido atribuído a Antônio Francisco Lisboa, o Aleijadinbo. Pertence a uma coleção particular localizada na capital do estado de São Paulo, como registrado Galeria de Arte do Sesi (1998, p. 174).

110. Juan Subias Galter, (1948, p. 326 e 591).

111. As figuras foram reproduzidas de Anna Maria Parsons e outros (1992, p. 31). Os autores descrevem as águias do sotobanco como "curiosa representación popular del Aguila Filipina, intencional o no". ou ao desaparecido sacrário de madeira da igreja paroquial de Valtajeros ${ }^{106}$, em Soria, também na Espanha.

Também encontramos a águia bicéfala na decoração de mobiliário pertencente a prelados e outros dignitários do clero, regular e secular - encostos de cadeiras e bancos decorados pela águia, cabeceira de leitos, contadores, cofres, tapetes - ou em peças do culto, como credências e cadeiras ${ }^{107}$.

E, em sacristias, nos lavatórios onde o sacerdote se purifica antes da missa, tal como o da igreja franciscana de Santa Maria dos Anjos, em Penedo, Alagoas, Brasil, cuja pia é sustentada por uma grande águia bicéfala (Figura 1 1); - mesmo programa iconográfico comparece em outro, datado de 1694, originário das Missões dos Sete Povos da Companhia de Jesus, no extremo sul do Brasil, mais especificamente, do Povo de São Lourenço (Figuras 12 ) 108. E, ainda, no Rio de Janeiro, no belíssimo lavatório em mármore embrechado, da sacristia da igreja de Santa Rita. A longa permanência do significado sacramental dessa representação surpreendentemente nos é indicada pelo magnífico lavabo de sacristia entalhado em pedra sabão originário de Minas Gerais ${ }^{109}$, Brasil, datado da segunda metade do século XVIII, cujas torneiras saem dos bicos de uma vigorosa águia bicéfala. Este tem até mesmo um antecedente também mineiro: no chafariz dito "dos Contos", o mais imponente dos chafarizes urbanos de Ouro Preto, inaugurado em 1745, a água sai dos bicos de uma cabeça bicéfala de águia.

São ainda reveladoras, a esse respeito, as pias de água benta de cariz popular, feitas de cerâmica policromada, uma de Manises e outra de Tervel, pertencentes ao Museu Sorolla, de Madri: a primeira delas apresenta, em relevo, um ostensório, com os 15 raios com estrelas (os 15 mistérios) nas pontas ao redor do disco, ladeado, nos cantos por São João e a Virgem Maria; e a segunda tem como decoração a própria Virgem do Rosário ${ }^{110}$. De ambas se desconhece a data.

A adoção de seu significado - ressurreição, purificação das culpas e pecados - pelos fiéis pode ser visto no fontanário da Casa da Torre, solar da primeira metade do século XVIII, situado em São João de Ver, Distrito de Aveiro, Portugal, encimado por uma águia bicéfala e as duas bicas com o formato de águia.

Num altar devotado à senhora da Candelária ou da Purificação, datado de finais do século XVII, que se encontra numa das missões franciscanas do Paraguai (mais precisamente o altar-mor da Missão de São Francisco de Ałyrá), a águia bicéfala está estampada em relevo por toda a parte. Duas dessas águias esculpidas figuram na raiz (sotobanco) do altar, ladeando a mesa. E, na base das colunas torsas (pseudo-salomônicas) que enquadram os dois primeiros andares do retábulo (quatro em cada um deles), há também uma águia bicéfala. Tudo isso, uma profusa alusão aos objetivos imperiais, milenaristas, da lgreja (Figuras 13 e 14) 111.

Em Minas Gerais, região brasileira de colonização mais tardia, cujas instituições começam a consolidar-se a partir de cerca de 1720, surgem manifestações ainda anteriores ao supracitado Chafariz dos Contos, como é caso 


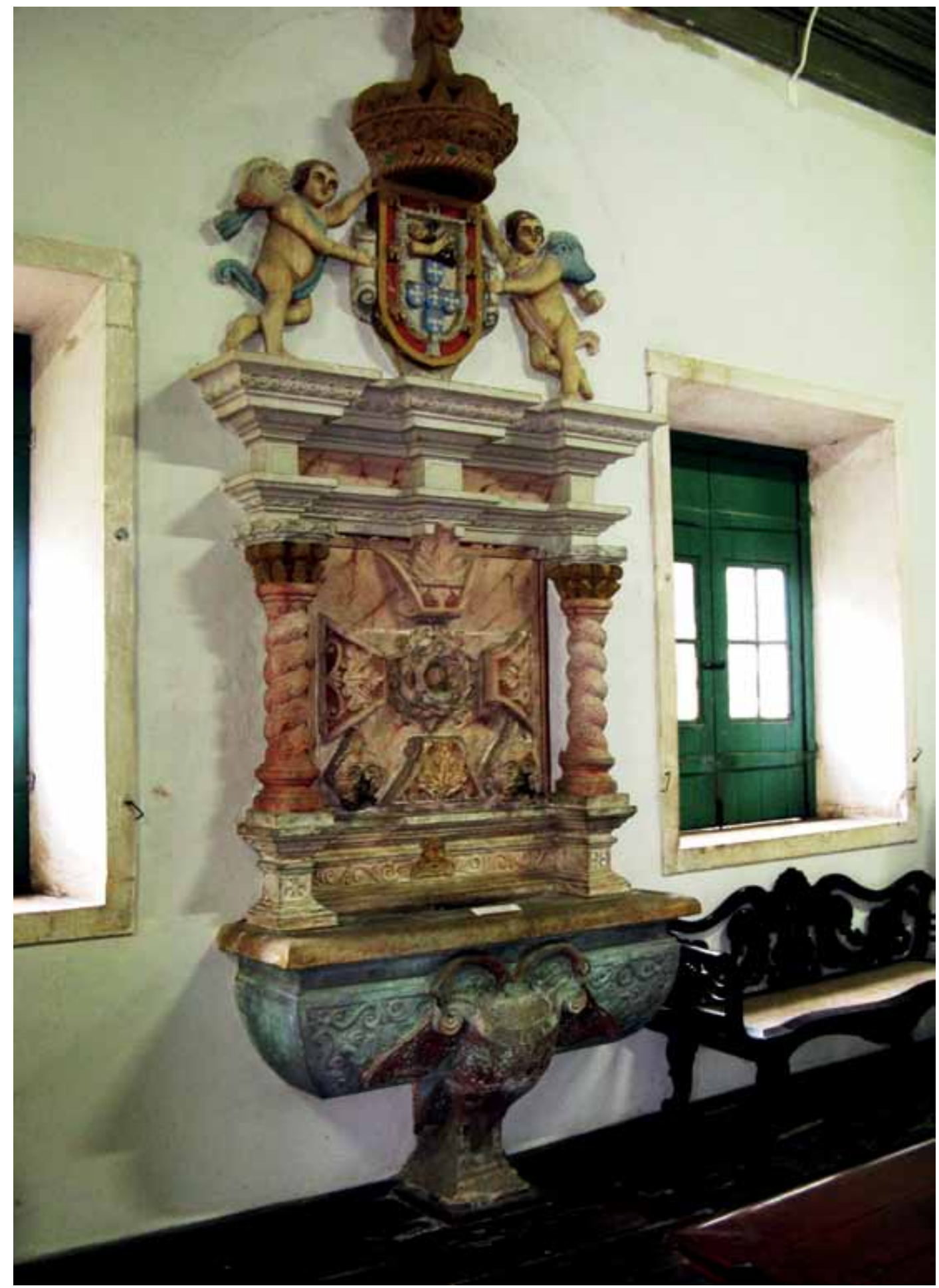

Figura 11 - Lavatório da sacristia do convento franciscano de Nossa Senhora dos Anjos, em Penedo, Alagoas, obra de fins do século XVII, início do XVIII. Uma grande águia bicéfala fronteia a taça da pia los dizeres da faixa presa nos bicos da águia estão ilegíveis). Fotografia de Jaelson Bitran Trindade, 2010. 


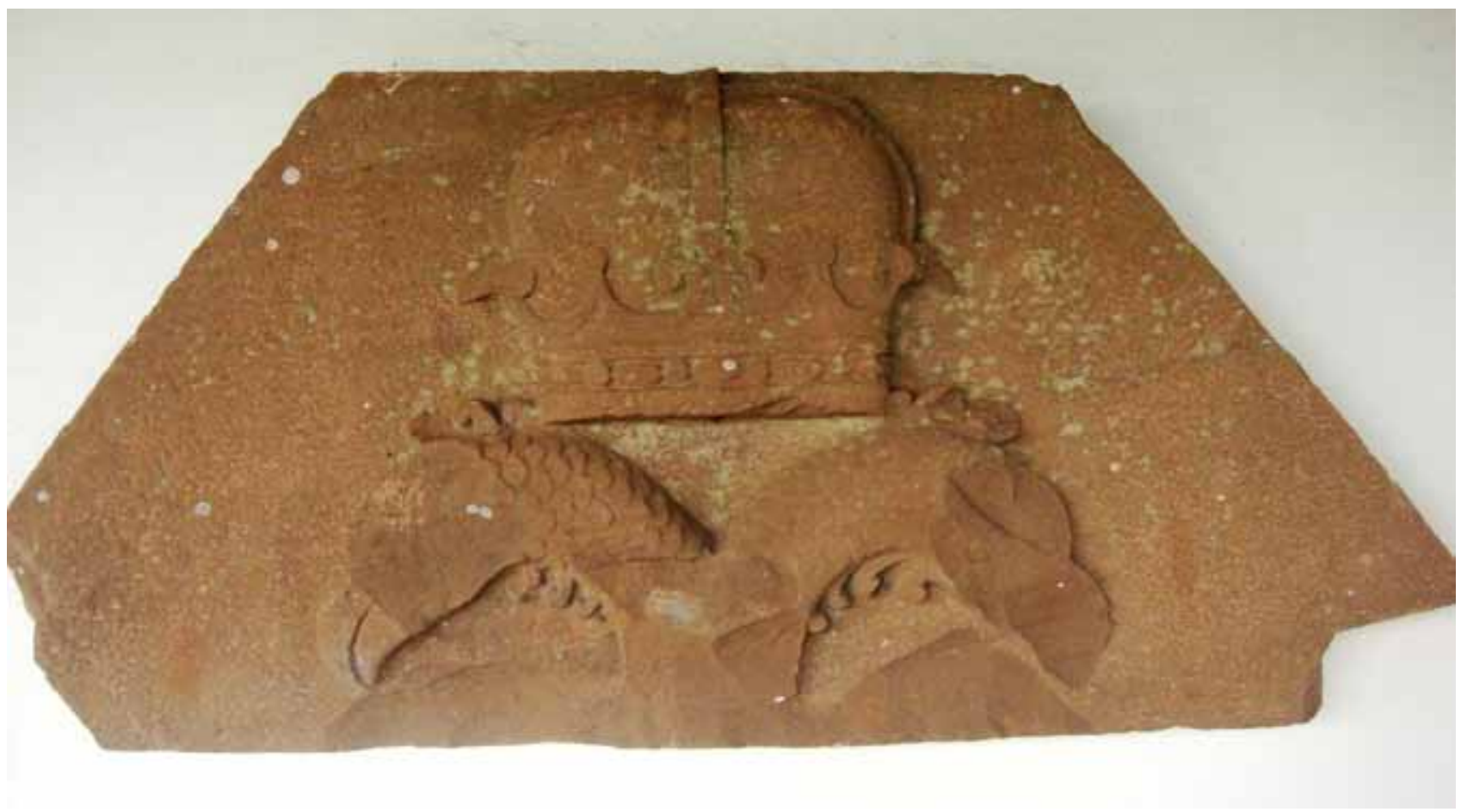

Figura 12 - Remanescente do espaldar em arenito do lavatório da sacristia da antiga missão jesuítica de São Lourenço, dos Sete Povos Guaranis. Este espaldar ainda estava inteiro em meados da década de 1840. Em um desenho feito na mesma época pelo naturalista francês Alfred Demersay, vê-se que a águia bicéfala tinha no centro do corpo um coração com o monograma IHS da Companhia de Jesus. O desenho foi publicado no Atlas do seu livro Histoire du Paraguay et des établissements des Jésuites. Fotografia de Isabela Souza, cedida pelo Museu das Missões, Ibram-MinC, São Miguel das Missões. 


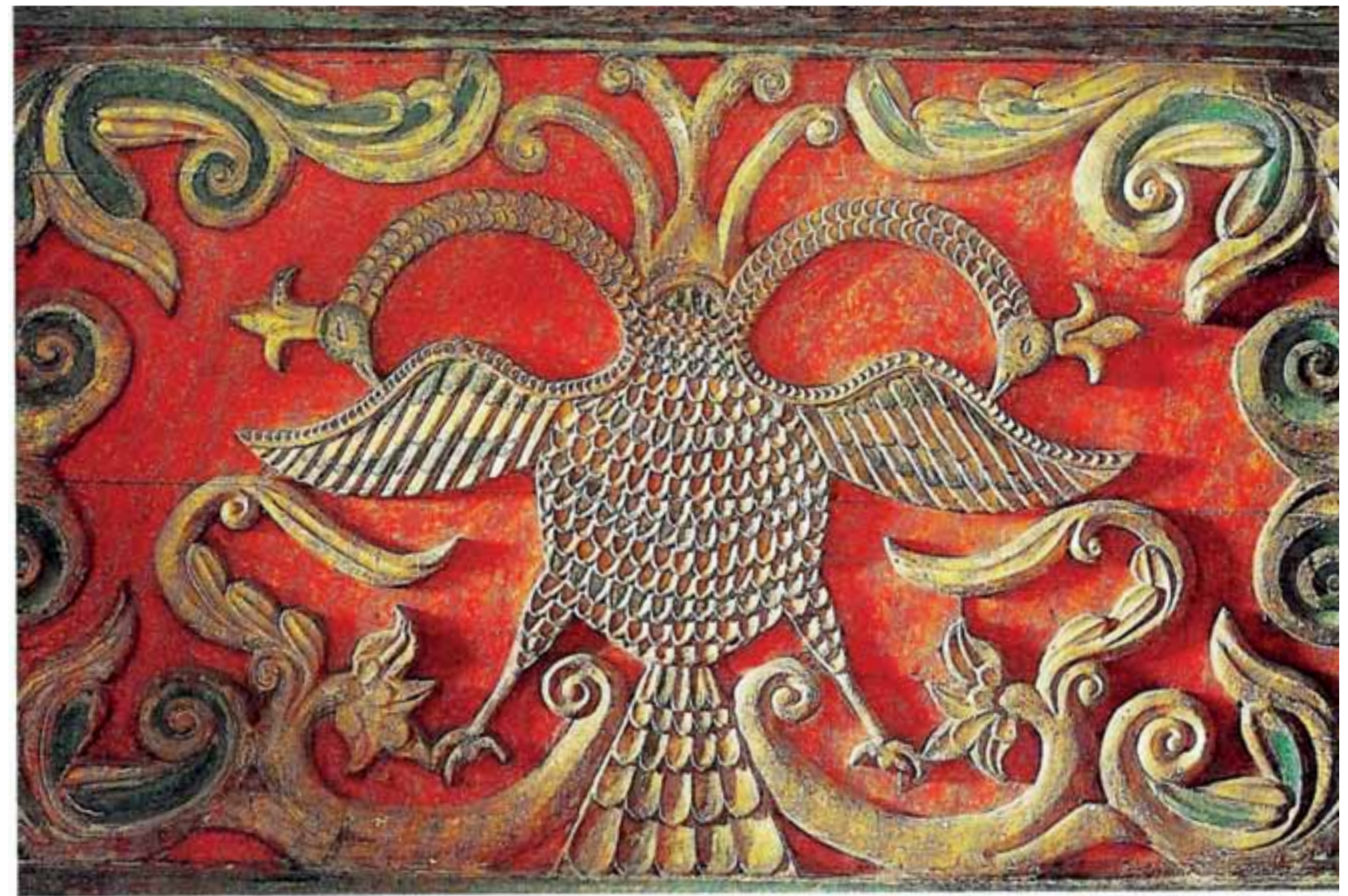

Figura 13 - Esta águia esculpida faz par com outra, no sotobanco do altar-mor da igreja de San Francisco de Atyrá, antiga missão franciscana no Departamento de Cordillera, Paraguai. A obra do altar é posterior ao incêndio sofrido pelo templo em 1672. Fotografia de Fernando Allen (cortesia). 


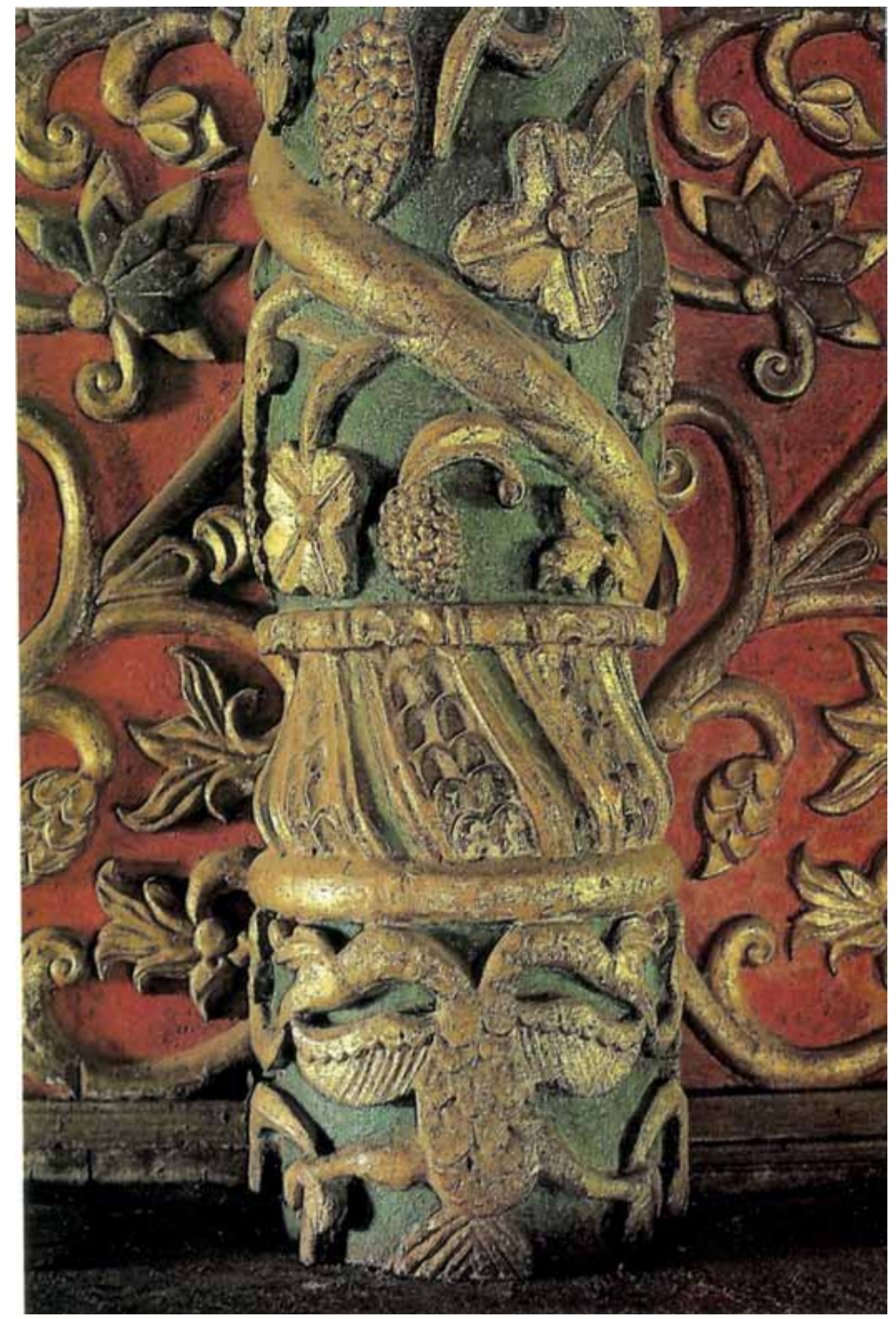

Figura 14 - Todas as colunas do altar-mor da igreja de Atyrá têm em seu pedestal águias bicéfalas em relevo. Fotografia de Fernando Allen (cortesia). 
do altar-mor da igreja matriz de Nossa Senhora da Conceição de Sabará, em cuja parte superior, em um canto e no outro, há uma águia como arremate.

No acervo do Museu da Inconfidência, em Ouro Preto (MG), há peças surpreendentes, com a representação da águia imperial apostólica, que são contemporâneas a situações especialíssimas ocorridas no campo religioso e político da região, nas quais se faz presente a ideia de estabelecimento do Quinto Império do Mundo 112. Na ornamentação lavrada no espaldar de couro de duas cadeiras "de estado", com pregaria em dourado, que pertenceram ao Senado da Câmara da antiga Vila Real de Nossa Senhora da Conceição do Sabará (novamente em Sabará), duas águias ladeiam a coroa real que encima o escudo do reino de Portugal (Figura 15). As duas águias aparecem noutra peça excepcional: uma lâmpada do Santíssimo Sacramento lessas lâmpadas sempre acesas, que anunciam a presença de Cristo no templo), de latão dourado, tendo em cada lado um peito e uma cabeça de águia, onde estão fixas as duas correntes pelas quais ela é pendurada (Figura 16).
112. As questões relativas aos movimentos sociorreligiosos e políticos em Minas Gerais no século XVIII passíveis de ser analisadas a partir do objeto-águia bicéfala constam desta bibliografia que venho estudando: Plínio Freire Gomes (1997); Carla Maria J. Anastasia (1998); Luciano R. de A.. Figueiredo (1999); Adriana Romeiro (2001); Laura de Mello e Souza (2006); Edeílson M. de Azevedo (2006); Luiz Carlos Villalta (2007); Leandro Pena Catão (2007a; 2007b); Tarcísio de Souza Gaspar (2008); e Claudia Cristina Azeredo Atallah (2009).

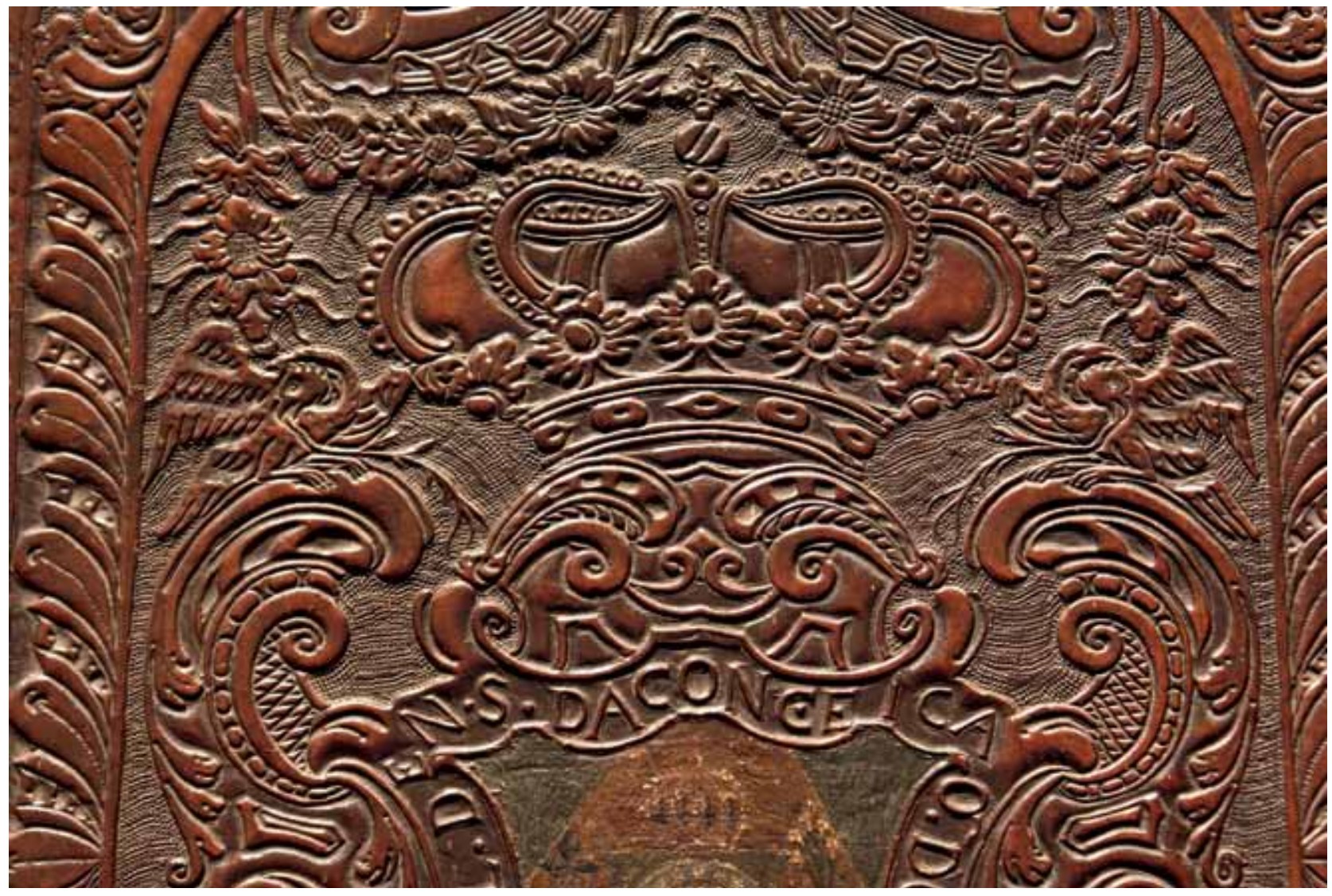

Figura 15 - Detalhe do encosto de uma das cadeiras da sala de reunião do antigo Senado da Câmara da Real Vila de Nossa Senhora da Conceição de Sabará. Há uma águia, com ramo de oliveira no bico, de cada lado da coroa real. Primeira metade do século XVIII. Museu da Inconfidência, Ouro Preto, Minas Gerais. Fotografia de Aldo Araújo - cortesia do Museu da Inconfidência, Ouro Preto - MG. 


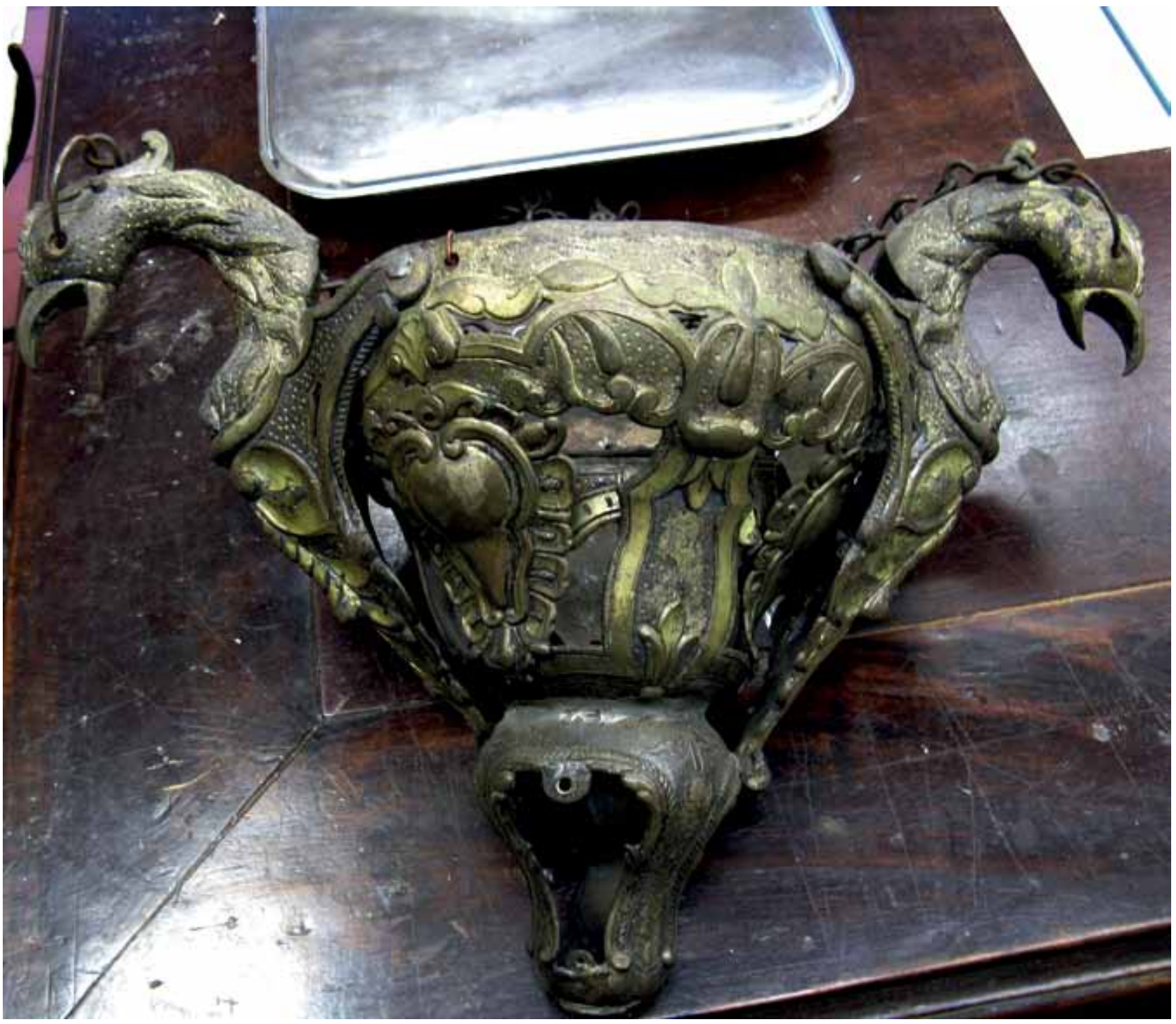

Figura 16 - Lâmpada do Santíssimo Sacramento, em latão dourado, com a forma de águia bicéfala. Museu da Inconfidência, Ouro Preto, Minas Gerais (procedente do antigo Museu da Arquidiocese de Mariana). Fotografia de Jaelson Bitran Trindade, 2010.

113. Ver Adriana. Romeiro (2001). O subtítulo do estudo é bem a propósito deste estudo sobre o tema da águia imperial.
Como dito antes, nos contextos em que aparece esse símbolo do Império de Cristo, há conspirações e utopias envolvendo o Quinto Império.

No Brasil, entre os anos de 1708 e 1740, é possível visualizar indivíduos e grupos de interesse, eclesiásticos e leigos, envolvidos com ideias de instauração do Quinto Império nas Minas Gerais e na Bahia. No caso de Minas, num dos episódios, a trama concebia a passagem do Infante D. Manuel para o Brasil, para aquela região mineradora, a fim de ser coroado Imperador da América Meridional, onde seria levantado o Quinto Império, tal como se pode ler em estudo da historiadora Adriana Romero ${ }^{113}$. 
único rastro, por enquanto, é o processo relativo ao português Pedro de Rates Henequim, dono de fortuna adquirida nas Minas entre 1702 e 1722, que voltou para o Reino, tendo sido denunciado de conspirações junto ao Príncipe D. Manuel em 1740. Foi preso e, depois de tudo tratado sob "inviolável segredo"114, passou a ser julgado como herege, iá na alçada do Santo Ofício, morrendo na fogueira num auto-de-fé em 1744.

Em Minas, Henequim andou por Vila Rica, Sabará e no Serro, região dos diamantes; teve contatos com potentados locais, ocupantes de cargos da administração e justiça da região, inclusive na composição do Senado da Câmara de Vereadores do Sabará, de onde vêm as citadas cadeiras, que hoje pertencem ao Museu da Inconfidência. $\bigcirc$ "visionário" também teve cargo de importância, enriqueceu, e diz-se que ele estava em Portugal como comissário dos magnatas da terra, para aquele objetivo junto ao Infante D. Manuel ${ }^{115}$.

Houve um padre Lopes de Carvalho, que residiu na Bahia, mas esteve morando em Minas, na mesma época da estada de Henequim. No começo dos anos de 1720, ele foi para Portugal e, tendo acolhida na Corte, revelou a El-Rei ser profeta e ter ido ali para the anunciar o Quinto Império. Quando aprisionado, confessou que, em Minas, viu papéis com as ideias quinto-imperiais do padre Vieira, nas mãos de padres jesuítas, teólogos. ${ }^{116}$. Também o padre Carvalho conheceu a morte num auto-de-fé.

No início da década de 1740, no Serro, antiga Vila do Príncipe, deuse um episódio, mal-conhecido. Por lá apareceu, e ficou, um mendigo, aparentando (pelo saber) ter sido padre ou noviço, conforme testemunhos. Infiltrouse entre ricos e pobres, brancos, negros mestiços, disse ser filho bastardo de D. João $V$ e de uma mulher de nome Vitória. Disse mais: era o "príncipe encoberto", mandado para as Minas pelo Pai Eterno e por El-Rei para redimir os que viviam em cativeiro, fazer com eles um exército, bater os mouros e "restaurar a Casa Santa". Foi preso e depois, dado como louco ${ }^{17}$.

Esses acontecimentos, sobre os quais falta muito para ser investigado, não podem ser vistos de modo isolado. E nem como situações retardatárias. Ao contrário, no contexto mundial, transoceânico, das primeiras quatro décadas do século XVIII - sobretudo nas monarquias coloniais, como as de Espanha e de Portugal, e mesmo na monarquia do cristianíssimo rei de França -, a ideia de Monarquia Universal ainda estava ativa, no plano político e no eclesial ${ }^{118}$.

Por um lado, há avanços e aprofundamentos na ação sobre povos e territórios não-cristãos. A ação missionária atingiu, no continente americano, uma extensão espetacular entre o último terço do século XVII e a década de 1740. Não houve esmorecimento na crença e na afirmação do Império de Cristo na Terra, como se vê tanto pelas obras em que se representa a águia imperial, como na literatura espiritual do período, na qual eclesiásticos falam da Quinta Monarquia ou Quinto Império. É influência do já defunto padre Antônio Vieira, cujas prédicas e cartas são reeditadas e editadas; o autor de maior fama e admiração "no mundo todo", traduzido para o espanhol, o italiano e até para o francês.

No caso português que vem sendo mencionado, setores do clero, da nobreza e do povo não abandonavam a possibilidade de ser o rei português
117. Ver Luiz Carlos Villalta (2007)

118. Ver Alexandre Haran (2000). 
119. Cf. Silvano Peloso (2007, p. 115-118).

120. Cf. Francisco Xavier de Menezes (1741, p. 1).

121. Cf. Luiz Carlos Vilalta (1999, p. 75).

122. Ver Alexei Bueno e outros (2002). ungido Imperador ou Vice-Cristo do Mundo, Príncipe da Paz, na crença de que a mão da Divina Providência também interviesse, em apoio aos esforços e intenções de muitos.

$O$ próprio rei $D$. João $V$ mostrou-se bastante interessado em que se organizasse e publicasse o que Vieira deixara escrito sob o título Clavis Prophetarum, já bastante divulgado (a matéria circulava em cópias parciais). Da mesma forma interessou-se o Cardeal da Cunha, e também o Marquês de Abrantes, embaixador do Rei Magnânimo em Roma, como mostra Silvano Peloso, em seu estudo sobre essa obra ${ }^{119}$.

Eram confessos admiradores do padre Vieira vários eruditos, da fidalguia, do clero e das artes liberais, ligados ou não à recém-formada (1720) Academia Real de História, entre eles o Conde da Ericeira e os padres teatinos Rafael Bluteau e D. Antônio Caetano de Sousa, o padre João Baptista de Castro e muitos outros.

Em 1741, o prestigioso fidalgo conde da Ericeira, cujo pai, o Conde Velho, fora muito ligado a Vieira, publica o poema heroico A Henriqueida, em que está presente a ideia de instauração da Quinta Monarquia ou Quinto Império (usa as duas expressões):

\footnotetext{
Europa foy da espada fulminante

Teatro ilustre, victima gloriosa,

Asia vio no seu braço a Cruz brilhante,

E ficou do seu nome temerosa:

De Africa a gente barbara, e triunfante

Se the postrou rendida, e receosa

Para ser fundador de hum quinto Imperio

Que do Mundo domine outro Emisferio ${ }^{120}$.
}

O letrado baiano e filojesuíta Sebastião da Rocha Pita (1660-1738), autor da História da América Portuguesa de 1500 a 1724 e, em 1709, de um opúsculo sobre o Dó na Bahia pela morte do rei Pedro II, é explicitamente um adepto da doutrina do Quinto Império, como nos informa Luiz Carlos Villalta ${ }^{121}$. E entre os franciscanos destaca-se Frei Apolinário da Conceição, capucho da Província da Conceição, no Brasil, autor do Claustro Franciscano, erecto no Domínio da Coroa Portugueza, e estabelecido sobre dezesseis Venerabilissimas Columnas, publicado em 1740.

Ainda a compor a história política e religiosa (e artística) das Minas Gerais (e de Portugal), resta assinalar o cata-vento em forma de águia bicéfala, assentada numa esfera armilar, que arremata a torre da igreja de Nossa Senhora do Rosário dos Homens Pretos em Diamantina, erguido por volta de 1728. Em Minas Gerais, é o único elemento, que se conhece, associado ao exterior de um edifício religioso. Mas não é o único no Brasil. A igreja conventual dos franciscanos, de lgarassu, Pernambuco, no litoral, tem em seu frontão uma águia bicéfala ${ }^{122}$.

Em Portugal, as igrejas com o emblema da águia na fachada (há várias) estão associadas à Ordem de Santo Agostinho. Dois exemplos foram citados neste estudo: Coimbra e Évora. 
Na América hispânica, as ocorrências desse tipo são abundantes, interna e externamente aos edifícios, especialmente no México. Esse motivo pode ser encontrado, por exemplo, arrematando portadas externas ou internas (Capela do Hospital de Santa Cruz, Santa Cruz de Flores, Méxicol, em fachadas de igrejas em que há ornamentação datada da segunda metade do XVII, em especial na América hispânica, seja ou não em igrejas da Companhia de Jesus, porque padres dominicanos, difusores iniciais (século XIII) da devoção do Rosário da Virgem, mercedários, agostinianos e mesmo franciscanos, cujas igrejas exaltam a mediação da intitulada Rainha dos Anjos, indicam e reforçam a defesa da lgreja Católica também lançando mão dessa simbologia.

No México, por exemplo, encimando a porta sul da igreja do convento de Santa Mônica (1720), das monjas de Santo Agostinho, em Guadalajara, no estado de Jalisco, vê-se uma grande águia bicéfala em relevo. E a edícula, acrescentada no século XVII ao portal norte da igreja de San Bernardino, dos franciscanos, em Xochimilco (Distrito Federal), também exibe em seu coroamento uma águia bicéfala ${ }^{123}$. Entre os dominicanos, são notáveis as duas águias bicéfalas em relevo na fachada da igreja de San Domingos, em San Cristóbal de Las Casas, Chiapas ${ }^{124}$. Essas são algumas ocorrências entre muitas similares existentes na América hispânica.

A águia bicéfala também decora a face dianteira de púlpitos, lugar onde se prega o Evangelho. Na igreja de San Domenico (1688), em Ceglia Messapica, Lecce, Itália, há um ostentando o símbolo ${ }^{125}$. $\bigcirc$ belo púlpito da igreja da Senhora do Terço (novamente aqui a referência ao Rosário), em Barcelos, Portugal, e o da igreja de Nossa Senhora da Misericórdia, em Olinda, Pernambuco (Brasil), ambos da segunda década do Setecentos, são outros dois exemplos. O Rosário é "a voz do Evangelho", dizia o célebre orador padre Antônio Vieira, no Sermão do Rosário (1654), publicado em 1686 em Lisboa. Nas igrejas paroquiais o altar da Senhora do Rosário geralmente ocupava uma posição colateral em relação ao arco triunfal, precisamente o lado do Evangelho, fazendo par com o da Epístola, dedicado ao Cristo Crucificado e a São Miguel e Almas, situação claramente salvífica.

Na capela de Santo Antônio de Lisboa, junto à casa-grande de uma fazenda seiscentista (São Roque, São Paulo, Brasil), a águia bicéfala coroada aparece na face dianteira do púlpito. Esse data de uma época em que os serviços religiosos destinados aos proprietários (e a catequese dos indígenas que ali trabalhavam compulsoriamente) eram realizados pelos padres da Companhia de Jesus residentes no Embu Mirim, sendo notório um deles, o padre Belchior de Pontes, cuja vida e milagres atribuídos foram narrados pelo jesuíta Manuel da Fonseca (também paulista como o seu biografado), em livro publicado em Lisboa no ano de 1752. De fato, a igreja e residência remanescentes da antiga Aldeia de Embu e a sede rural hoje conhecida como Sítio Santo Antônio, são próximas entre si. A capela foi benta em 1686 (Figuras 17 e 18).

Não há que estranhar esse fato. $\bigcirc$ caso da capelinha paulista remete para o singelo oratório de uma propriedade rural equatoriana, que José Gabriel Navarro nos mostra em seu livro Artes Plásticas Equatorianas: a dupla porta divide
123. Cf. Elizabeth Wilder Weismann (1950, p. 43 e 116).

124. A Ordem de São Domingos, é a Ordem dos Pregadores: prega a defesa da Igreja contra a heresia e proclama a fidelidade e devoção ao Pontífice e à Igreja de Cristo.

125. A águia bicéfala entalhada ou esculpida em caixas de púlpitos tem sua razão de ser: nesse local ela está deliberadamente associada à palavra da fé, à ideia de Verdade da Fé, verdade do Evangelho. 


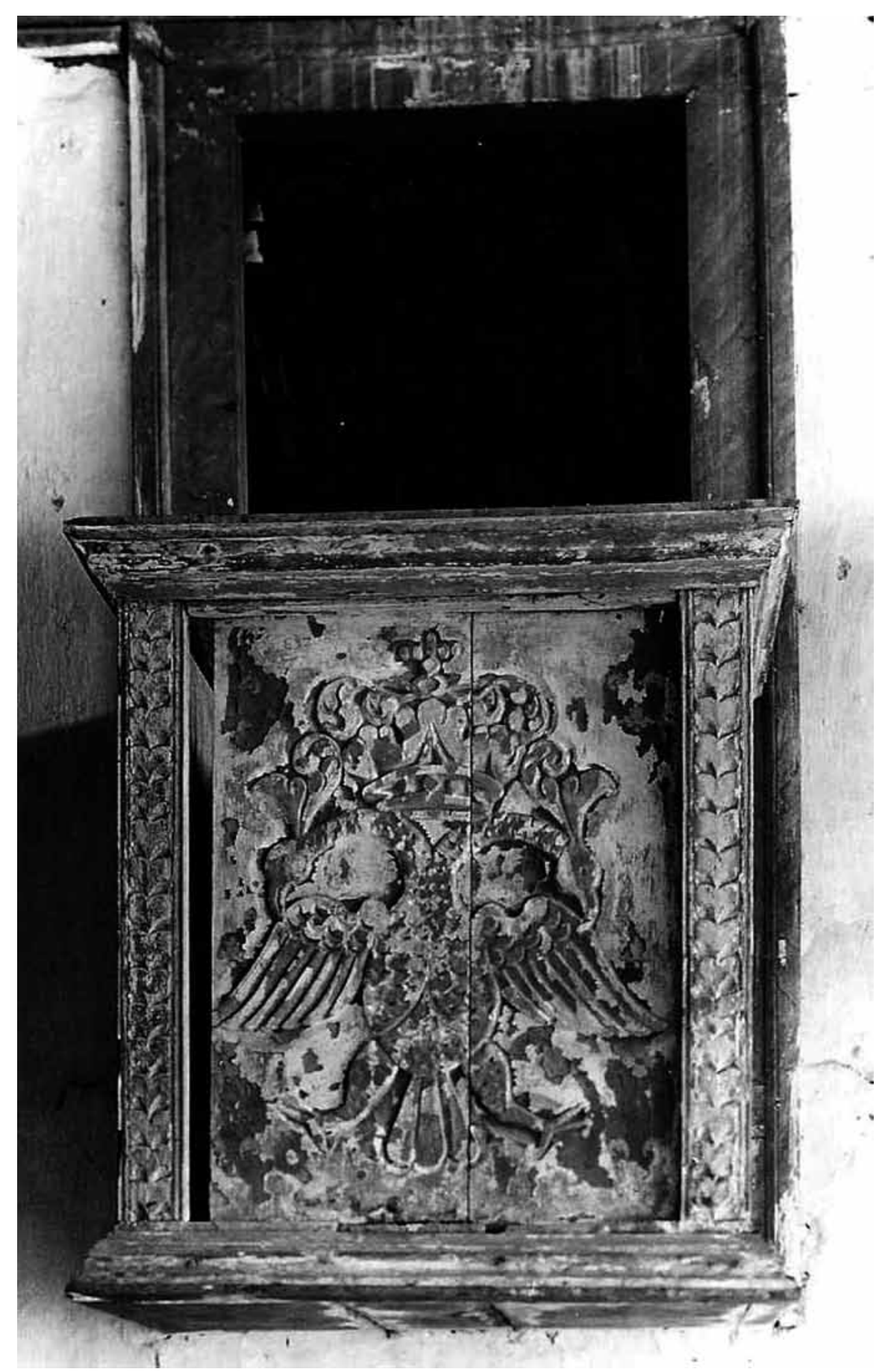

Figura 17 - Púlpito da capela de Santo Antônio de Lisboa (c. 1686). São Roque, São Paulo (Brasil). Fotografia de Germano Graeser, 1940 - Arquivo da Superintendência do IPHAN em São Paulo. 


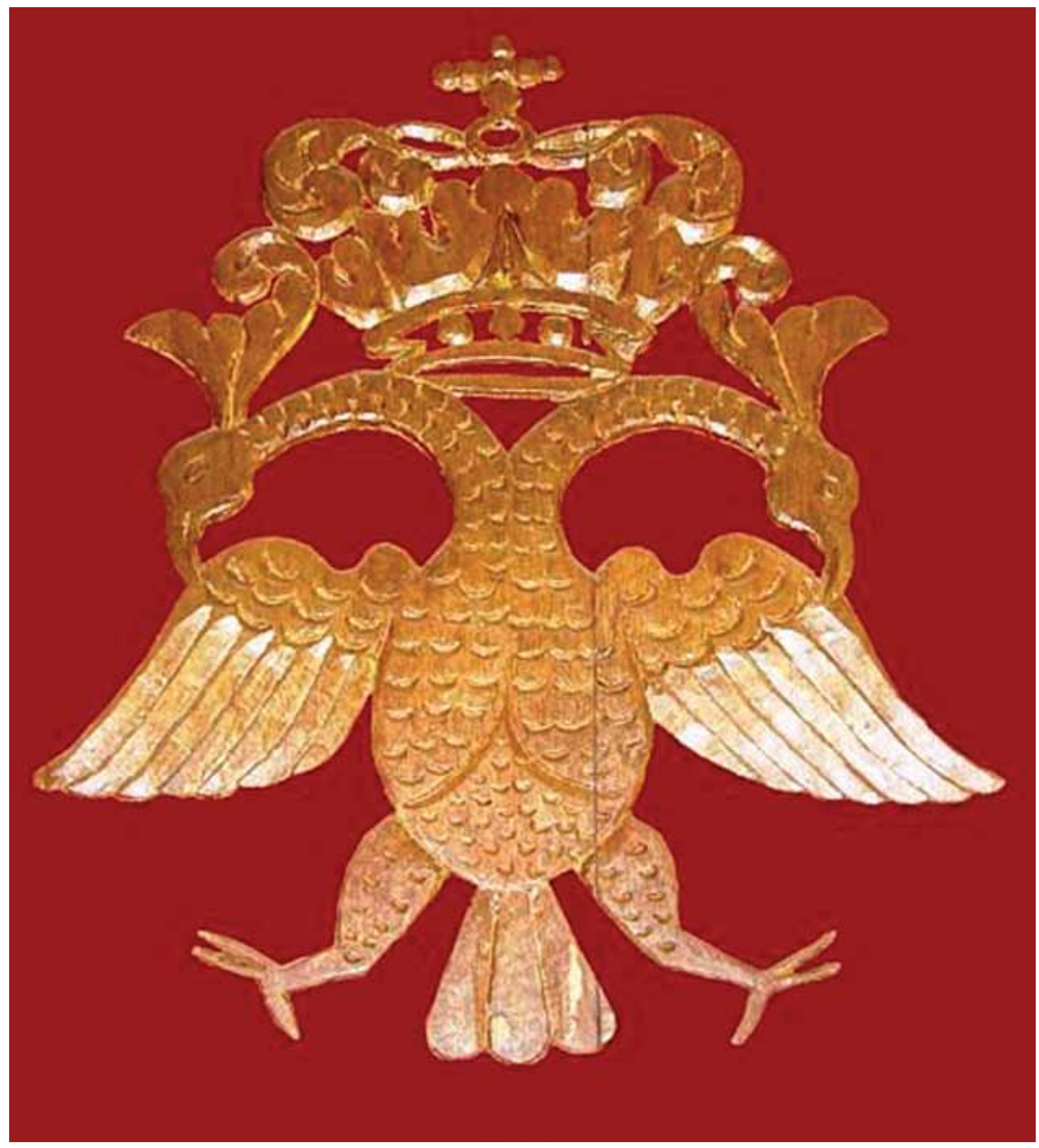

Figura 18 - Detalhe da face fronteira do púlpito, restaurado, apresentando hoje a águia em ouro e o fundo carmesim. Arquivo da Superintendência do IPHAN em São Paulo. 
126. Cf. José Gabriel Navarro (1945, fig. 47).

127. Cf Tilde Canti (1980, figs 94, 80, 101 e 98).

128. Devo a Fernando Quiles Garcia, historiador de arte da Universidad de Sevilla, a informação de que, segundo seus estudos, esta tela do Museo Catedralício de Zamora é obra do pintor sevilhano Domingo Martínez (16801749). ao meio a águia bicéfala, ao cimo, e, em cada uma das folhas da porta, um vaso de flores (fons vitae) trazendo um sol no arremate, o da esquerda, com o nome de Jesus, e o da direita, com o nome de Maria: o Império Universal, a lgreja Una, a Paz Universal $^{126}$. E porque não citar de novo, aqui, a capela de engenho de açúcar, em João Pessoa, Paraíba, cujo altar era arrematado por uma águia bicéfala "cercando um sol com as palavras 'Ave Maria'", que Germain Bazin localizou em suas pesquisas? E, voltando ao Equador, no convento "de la Pura y Limpia Concepción", de Quito, pode ser visto um impressionante oratório portátil em forma de águia bicéfala, que acolhia a imagem de "Nuestra Señora de la Paz" (Figura 19).

Retornando a São Paulo, no Brasil (Brasil), a cerca de uns 30 quilômetros do sítio e capela de Santo Antônio, antes citado, encontra-se a igreja e residência dos jesuítas da antiga missão cristã de Nossa Senhora do Rosário de Embu-Mirim, criada em 1623, onde os índios outrora ali aldeados seguiam um programa de culto e de trabalho estritamente interno, não prestando serviço aos colonos. Evidentemente, os colonos que moravam mais próximos às terras dos jesuítas podiam ir lá assistir cerimônias do culto e celebrações como, entre outras, as da Paixão. A igreja foi reformada na década de 1690 e a nova residência foi concluída por volta de 1735 (deve datar dessa época o altar-mor da igreja). Na igreja, dedicada a Nossa Senhora do Rosário, no tímpano formado pelas arquivoltas, os dois altares colaterais em estilo nacional português (característico das décadas de 1680-1690) exibem uma águia bicéfala coroada - a coroa da Virgem, "Imperatriz de todo o Orbe" (Figuras 20 e 21). Tal cenografia da igreja do Embu faz lembrar a doutrina messiânica do padre Vieira, de que nos gentios está o começo da conversão universal, pela pregação dos verdadeiros pregadores.

No Museu Paulista, da Universidade de São Paulo, pode ser encontrado mobiliário da segunda metade do século XVII com o motivo da águia bicéfala lavrado no couro do espaldar, como é o caso de duas "cadeiras de sola", uma delas de "interpretação brasileira do estilo português" daquela época, segundo especialista (Figuras 22, 23 e 24). O mesmo motivo poder ser encontrado em outras, de mais fino lavrado e estrutura, como a que existia em 1980 nas coleções de Djalma Lessa, do Rio de Janeiro (RJ), e de João Hermes Pereira de Araújo, de Braślia (DF), as três datadas da primeira metade do século XVIII' ${ }^{27}$. Contemporaneamente, em Portugal, Espanha e nos antigos domínios hispano-americanos, há numerosos móveis de assentos com o emblema da águia bicéfala.

A associação entre a Virgem e a águia bicéfala também aparece, com clareza, na tela - atribuída a Domingo Martínez ${ }^{128}$, sevilhano, remontando aos primeiros anos do século XVIII - representando a Virgem e o Menino, emoldurada por uma vigorosa talha revestida de ouro em forma de águia bicéfala, na Catedral de Zamora, Espanha (Figura 25). E numa pintura sul-americana de cerca do último quarto do século XVII, existente em Nova Granada (atual Colômbia), que representa a Virgen de Monguí, em que o Menino Jesus traz pendente, num colar de ouro, uma águia bicéfala (Figura 26). 


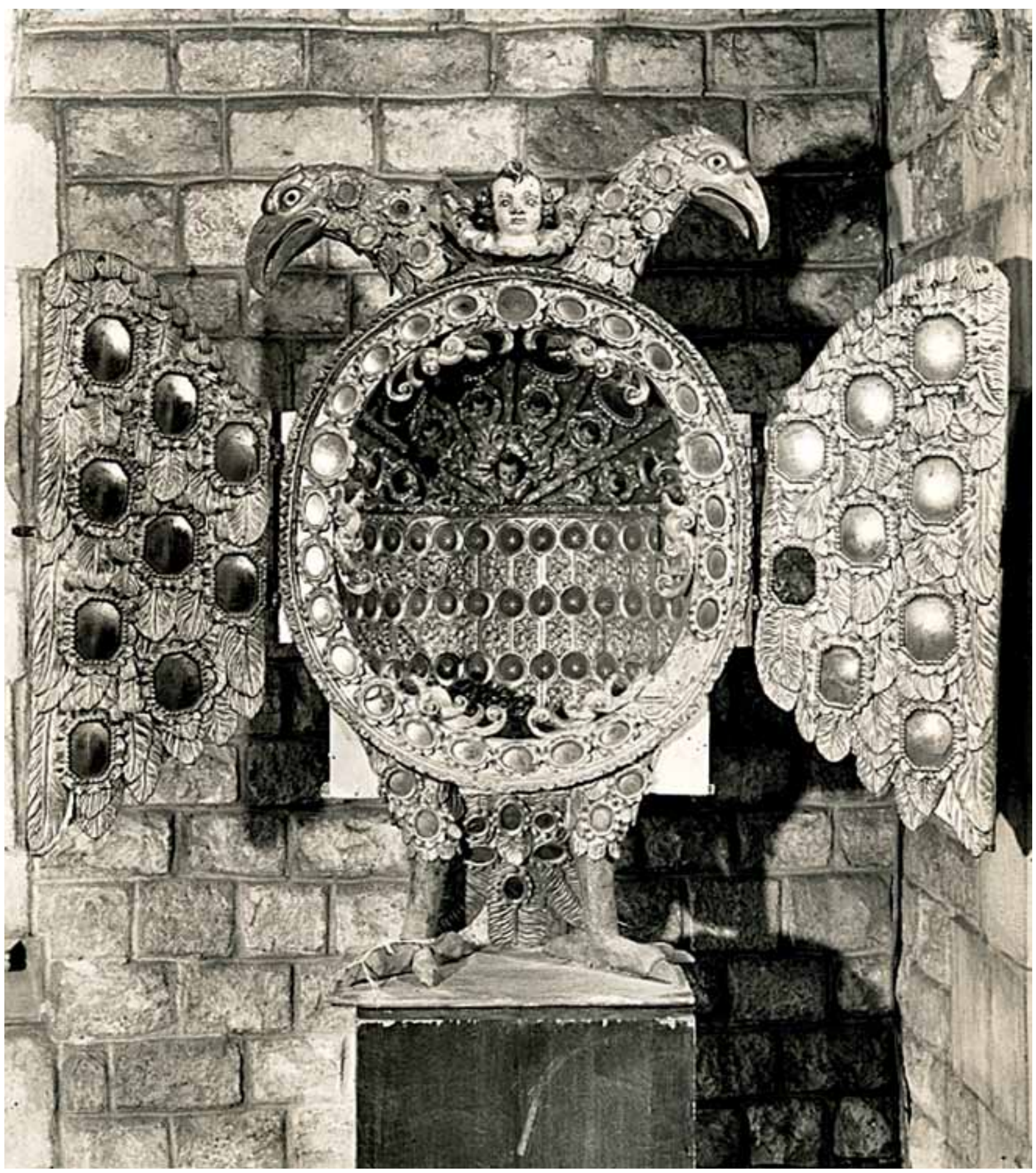

Figura 19 - Oratório portátil em forma de águia bicéfala, pertencente ao convento De la Pura y Limpia Concepción (La Concepción), em Quito, Equador. Coleção D. Diego Angulo Iñiguez, Consejo Superior de Investigaciones Científicas, Centro de Ciencias Humanas y Sociales, Unidad de Tratamiento Archivístico y Documentación, Madri, Espanha. Foto do historiador espanhol Diego Angulo (década de 1930). 


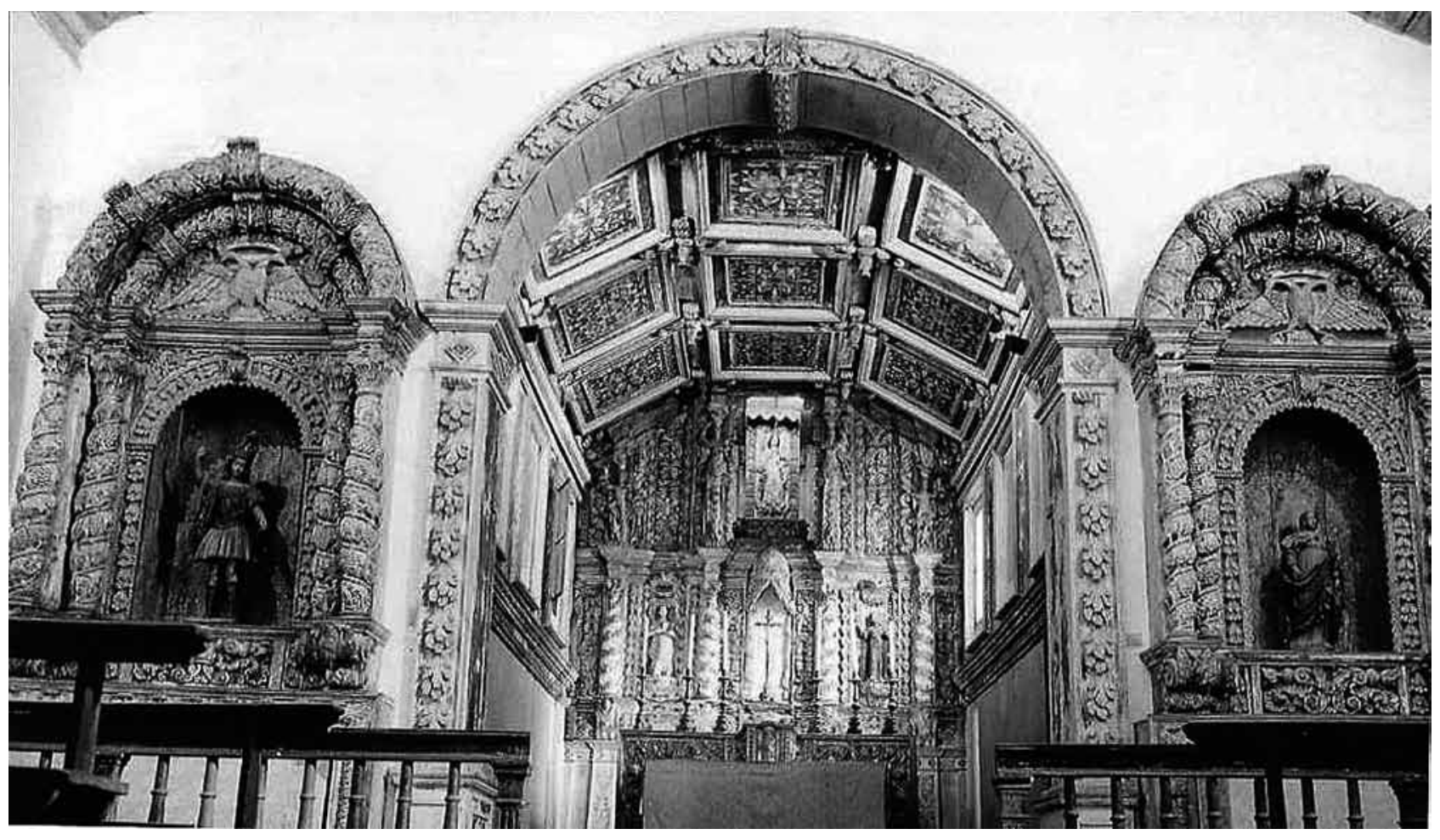

Figura 20 - Altares colaterais da igreja de Nossa Senhora do Rosário (c. 1690-1700). Antiga missão jesútica de Embu Mirim. Embu, São Paulo (Brasil). Fotografia de Germano Graeser, 1941 - Arquivo da Superintendência do IPHAN em São Paulo. 


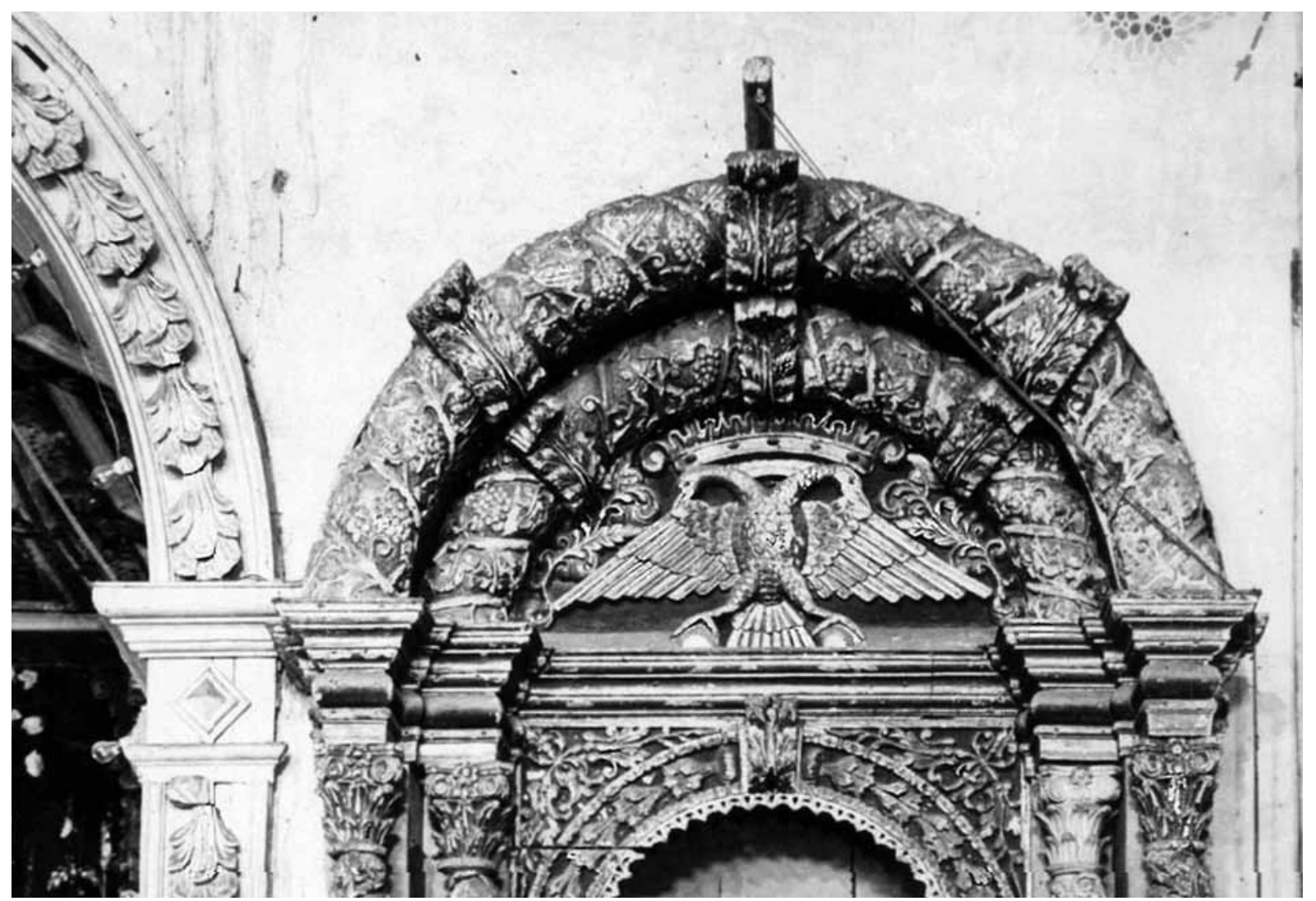

Figura 21 - Detalhe: o tímpano com a águia bicéfala do altar sob a invocação de São Miguel e Almas, colateral ao arco-cruzeiro. Fotografia de Germano Graeser, 1941 - Arquivo da Superintendência do IPHAN em São Paulo. 


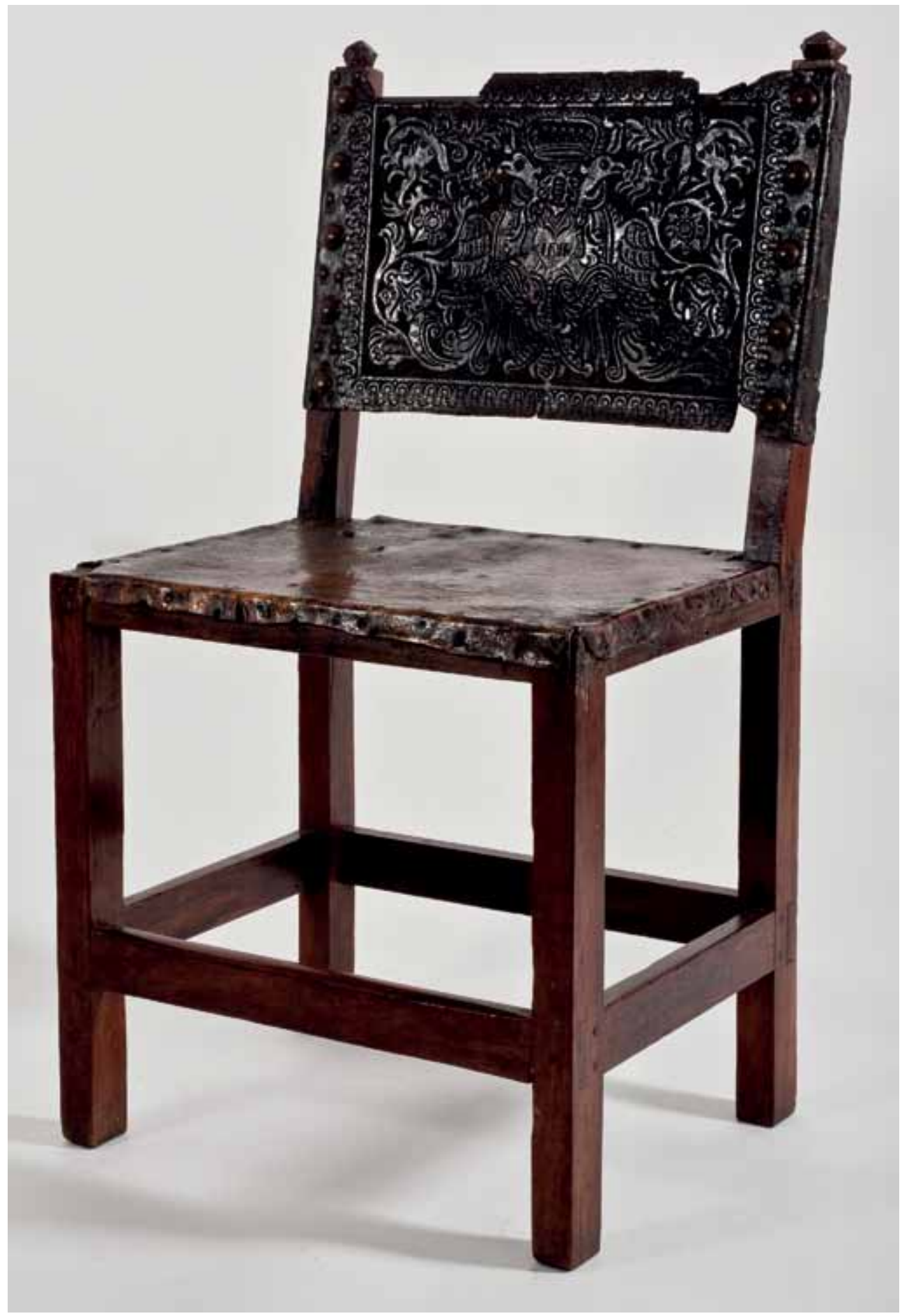

Figura 22 - "Cadeira de sola", de madeira e couro lavrado, século XVII ou início do século XVIII, com o emblema da águia bicéfala no centro do espaldar. Neste móvel, a águia bicéfala lavrada no espaldar é coroada e tem no centro do corpo um coração com monograma. Fotografia de Hélio Nobre. Acervo do Museu Paulista da Universidade de São Paulo, São Paulo. 


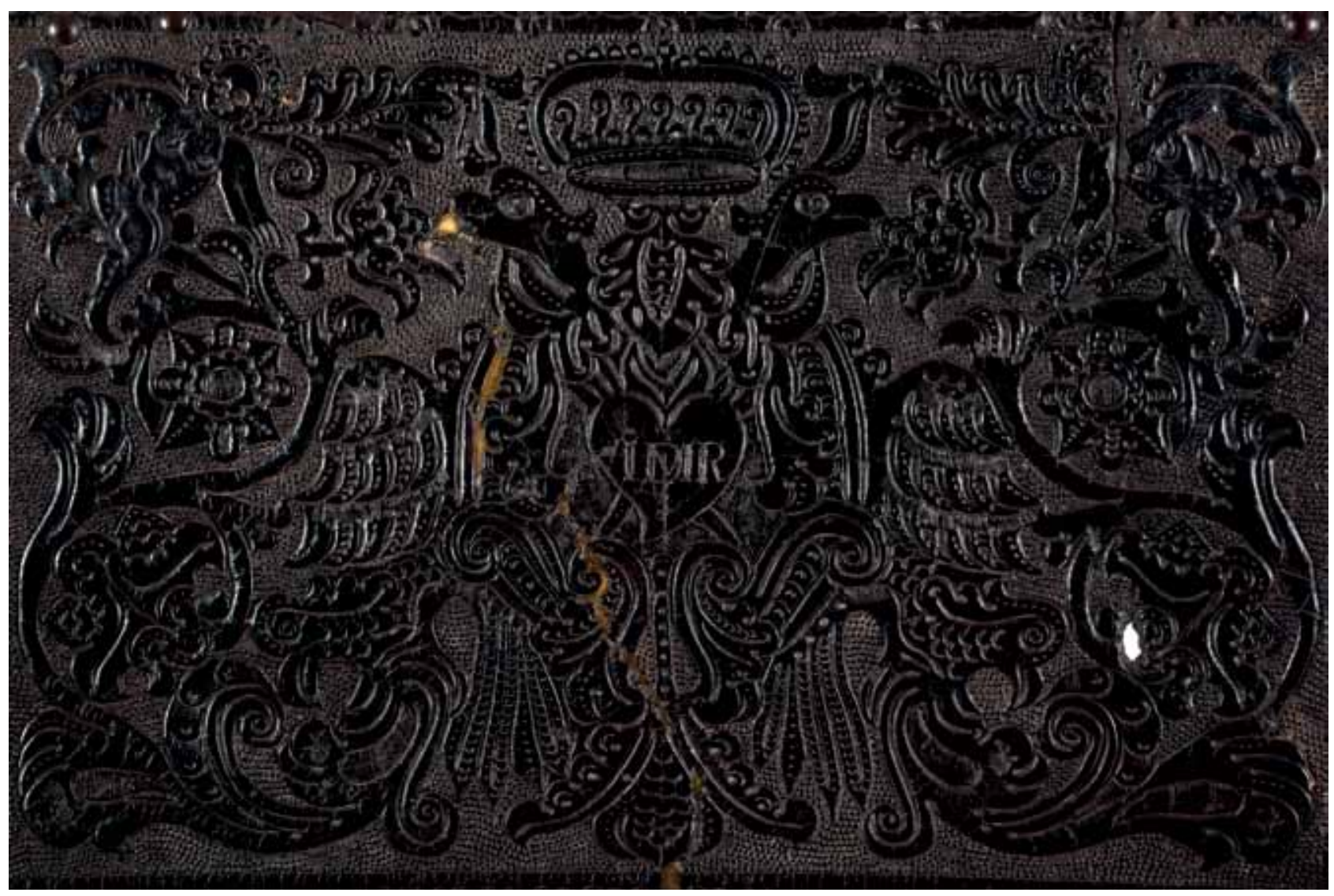

Figura 23 - Detalhe do espaldar da "cadeira de sola" apresentada na figura 22. Fotografia de Hélio Nobre. Acervo do Museu Paulista da Universidade de São Paulo, São Paulo. 


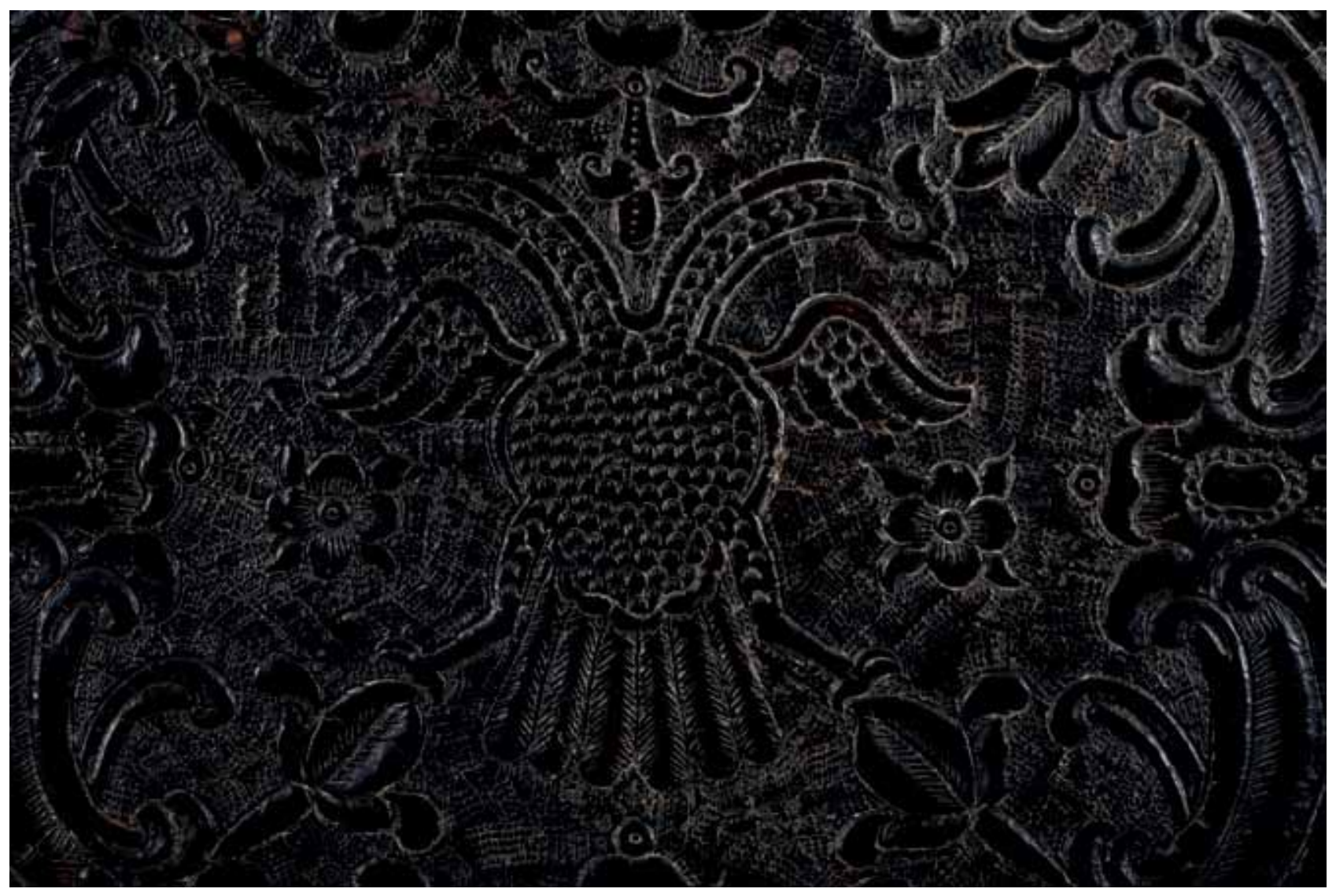

Figura 24 - Detalhe de outra "cadeira de sola" do Museu Paulista, de madeira e couro lavrado, século XVII ou início do século XVIII, com o emblema da águia bicéfala no centro do espaldar. Fotografia de Hélio Nobre. Acervo do Museu Paulista da Universidade de São Paulo, São Paulo. 


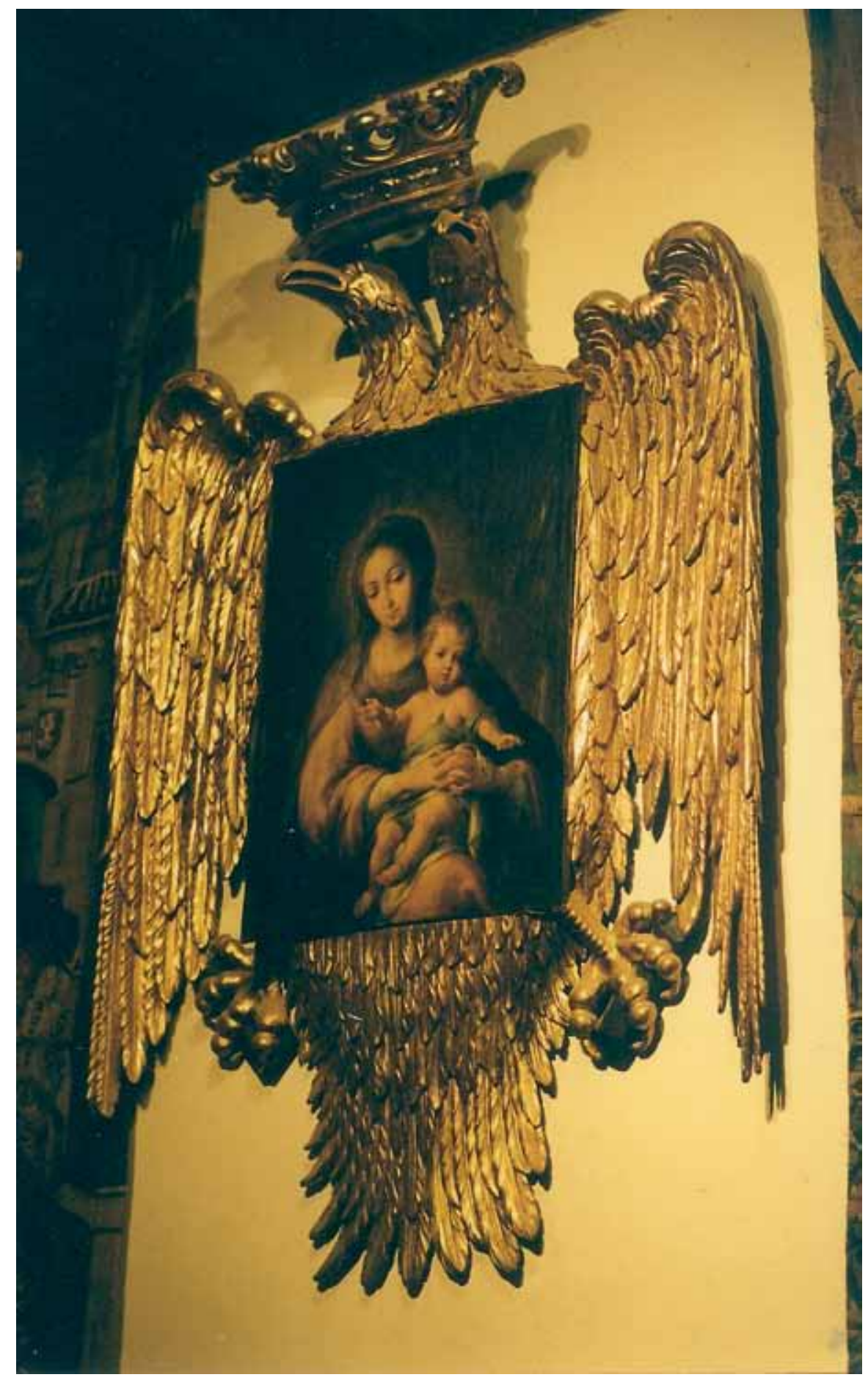

Figura 25 - A Senhora e o Menino (atribuída a Domingo Martínez), fim do século XVII, princípio do XVIII. Museu da Catedral de Zamora, Espanha. Quando de sua feitura, figurou no gabinete do Bispo de Zamora. Fotografia de Jaelson Bitran Trindade, 1999. 


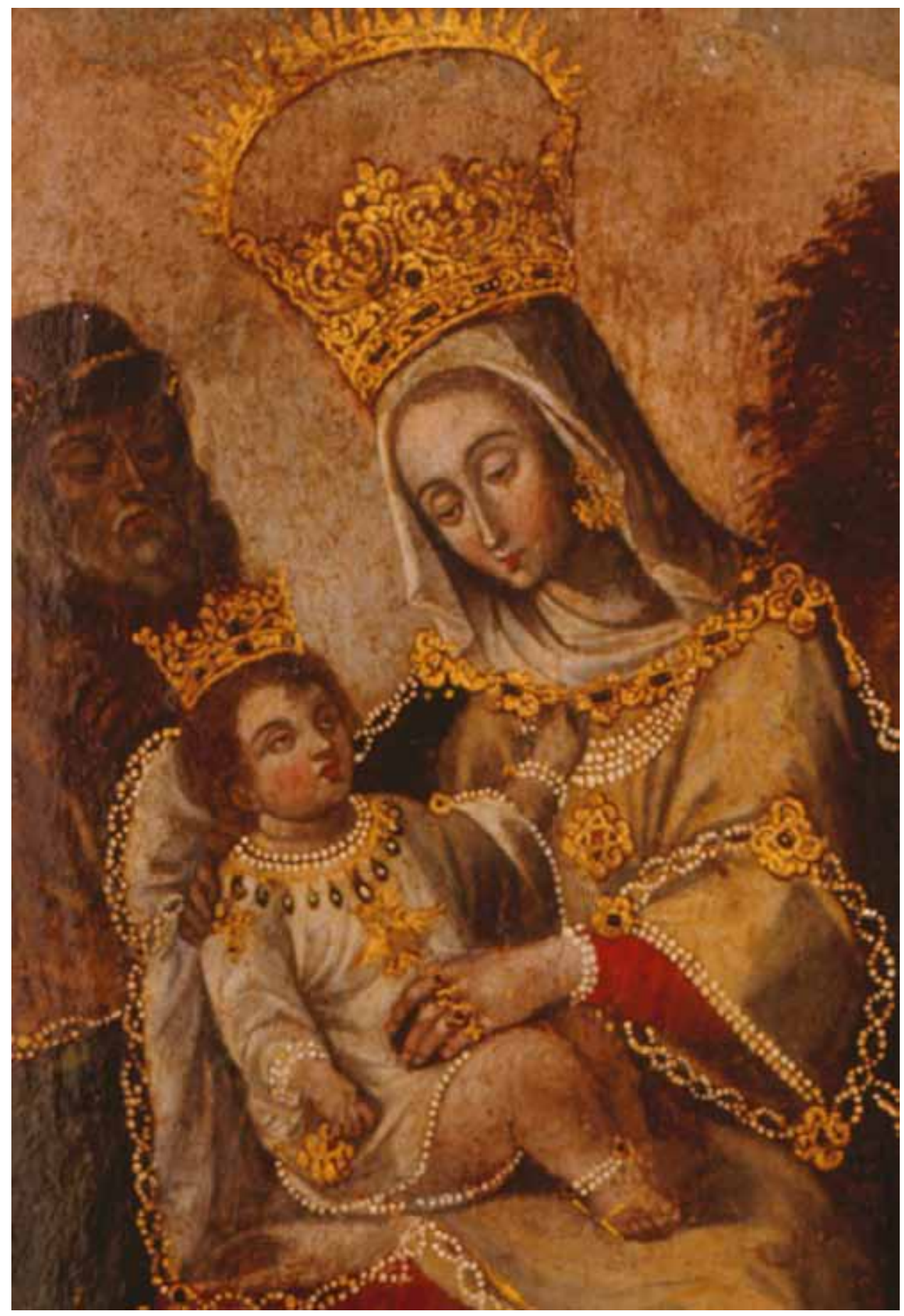

Figura 26 - A Virgem de Monguí, pintura de autor anônimo, século XVIII, Nova Granada lColômbia). Museo de America, Madri. A Virgem Mãe e o Menino-Deus, Senhor e Senhora do Cév e da Terra conforme a exegese bíblica do Catolicismo, miram um ao outro: a criança traz uma águia bicéfala pendurada num colar de ouro. Fotografia de Joaquín Otero Ubeda. Arquivo do Museo de America, Madri. 
Em Puebla, México, o baixo-relevo de talha, com o rosário de contas ladeado por dois pássaros, que aparece na esplêndida decoração da capela do Rosário da igreja de San Domingos, ganha, agora, outra conotação: são duas águias. Essa capela, inaugurada em 1690, foi louvada, na época, como a Oitava Maravilha do Mundo. Na sacristia da catedral da mesma cidade, duas telas - pintadas em 1675, a partir dos modelos de Rubens - apresentam os temas correlatos da Igreja Militante e da lgreja Triunfante.

Sem a chave apropriada de leitura não é possível, hoje, detectar essas inúmeras representações artísticas da águia bicéfala. E nem perceber a incidência que tal ideário - milenarista, messiânico, universalista e, mais claramente, quintoimperial - possa ter alcançado, ou seja, sua disseminação, seus adeptos vários, seus momentos de maior fôlego, seu canto de cisne.

$\bigcirc$ Quinto Império é o modo particular da universalização da monarquia cristã, via Casa Real de Portugal, tese explicitada pelo padre Antônio Vieira a partir da década de 1640129, encontrando afeiçoados entre a nobreza lusitana e em diversas ordens religiosas, além da Companhia de Jesus là qual pertencia o padre), intitulada de Milícia Universal (Igreja) de Cristo e Paladina da Virgem Santíssima. A ideia do advento de um Quinto Império também fazia afetos fora de Portugal, evidentemente do ponto de vista da plena união de uma monarquia terrena com a lgreja, sobrepondo-se a todos os demais monarcas cristãos, para conquista e conversão universal das quatro partes do mundo. Uma teologia política.

Veja-se o caso do escudo de pedra com as armas do reino de Portugal que encima a porta de entrada do edifício da Câmara da Vila da Madalena, na itha do Pico, Açores, Portugal'130: a Câmara foi instalada no ano de 1723. A Coroa monárquica sobre o escudo tem uma nota diferencial, pois está ladeada por dois pássaros (Figura 27). É uma representação inusual das armas do Reino português e, sendo um trabalho sem maior apuro técnico, hoje dia é senso comum que os pássaros ali postados são dois corvos, passando, o sentido deles, por curioso e enigmático.

Evidentemente, corvos ladeando a coroa não fazem sentido. Mas é possível encontrar a divisão da águia bicéfala em duas águias colocadas simetricamente no bordado de colchas, em peças de prataria, em louças seiscentistas, além de altares de igreja. Sempre significam a fé verdadeira, una e indivisível. Muitas vezes, sobre as águias separadas, aparecem dois corações (Cristo e a Virgem). Ou, então, duas águias tocando um coração situado entre ambas. A simbologia da devoção ao Sagrado Coração de Jesus e de Maria, de fins do século XVII, apresenta-se assim: dois corações lado a lado, com o monograma de Jesus (IHS) sob o um deles; e, sob o outro, o de Maria (AM); mas é possível também encontrar um só coração e dentro dele os dois nomes ${ }^{131}$.

que se vê na portada do Paço da Madalena do Pico são, a meu ver, duas águias. É a representação do Reino de Portugal como reino eleito, dado por Cristo para ser Império do seu Reino Consumado no Mundo.

Existe outra ocorrência similar: uma marca d'água, em papel produzido em Portugal no início da década de 1680, onde o escudo do Reino, o das "cinco
129. O primeiro texto no qual Vieira parece ter examinado a questão foi a Carta ao Bispo do Japão, em 1659 , sobre as Esperanças de Portugal, V Império do Mundo, fato que teria motivado a sua prisão pelo Santo Ofício, em 1663.

130. Cf. Helder Pacheco (1985, p. 125)

131. Ver Padre José Maria Maugeri (1743) 


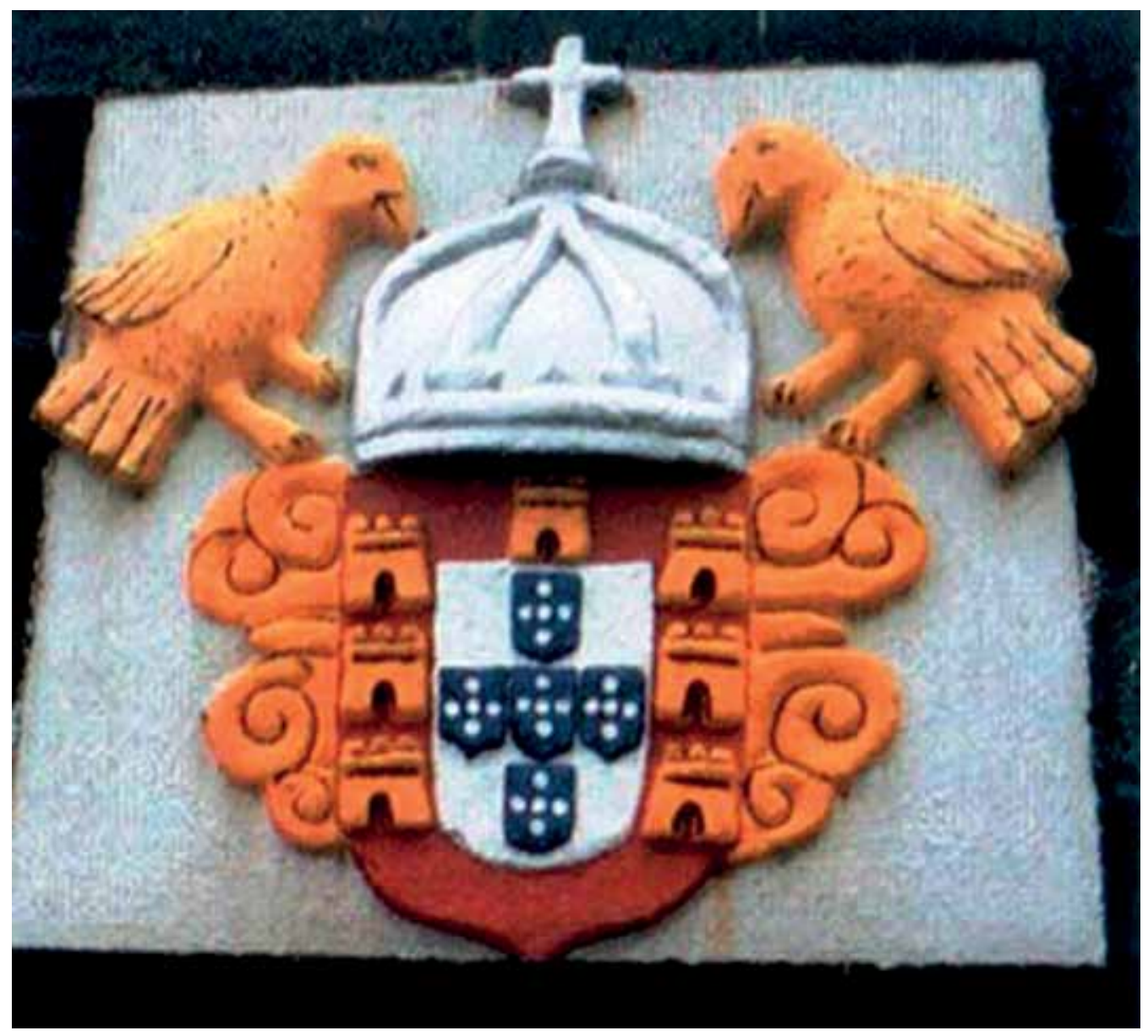

Figura 27 - Brasão de Armas do reino de Portugal. Portal dos Paços do Concelho (Câmara Municipal) da Vila da Madalena, Itha do Pico, Açores. Década de 1720. Fotografia cedida pela Direcção Regional da Cultura/Instituto Açoriano de Cultura - Inventário do Património Imóvel dos Açores.

132. Cf. João Amaral (1949, p. 474). chagas de Cristo", toma a forma do corpo de uma águia com duas cabeças na parte superior, sob a coroa (Figura 28). A data conhecida para essa marca ( 1683 ) coincide com a coroação do Regente Pedro II como Rei de Portugal ${ }^{132}$.

Inda que sejam corvos e não sejam águias os dois pássaros que ladeiam a coroa das armas do reino luso, ainda assim remetem para a condição de Portugal como reino eleito para ser o "Império do Mundo". E se forem mesmo corvos, tal evento, singular, só podia ser na época, em termos de anúncio profético, coisa portuguesa: corvos anunciáticos.

No mesmo ano em que se presume ter sido feito esse escudo na porta da Casa do Concelho da Madalena do Pico (1723), foi publicado em Lisboa um sermão que associa diretamente dois corvos ao prometido Império de Cristo, - Quinto Império, mas não na sua universalidade, como representação do Cristo e da Virgem na terra - para isso é sempre a águia o animal utilizado. A associação 


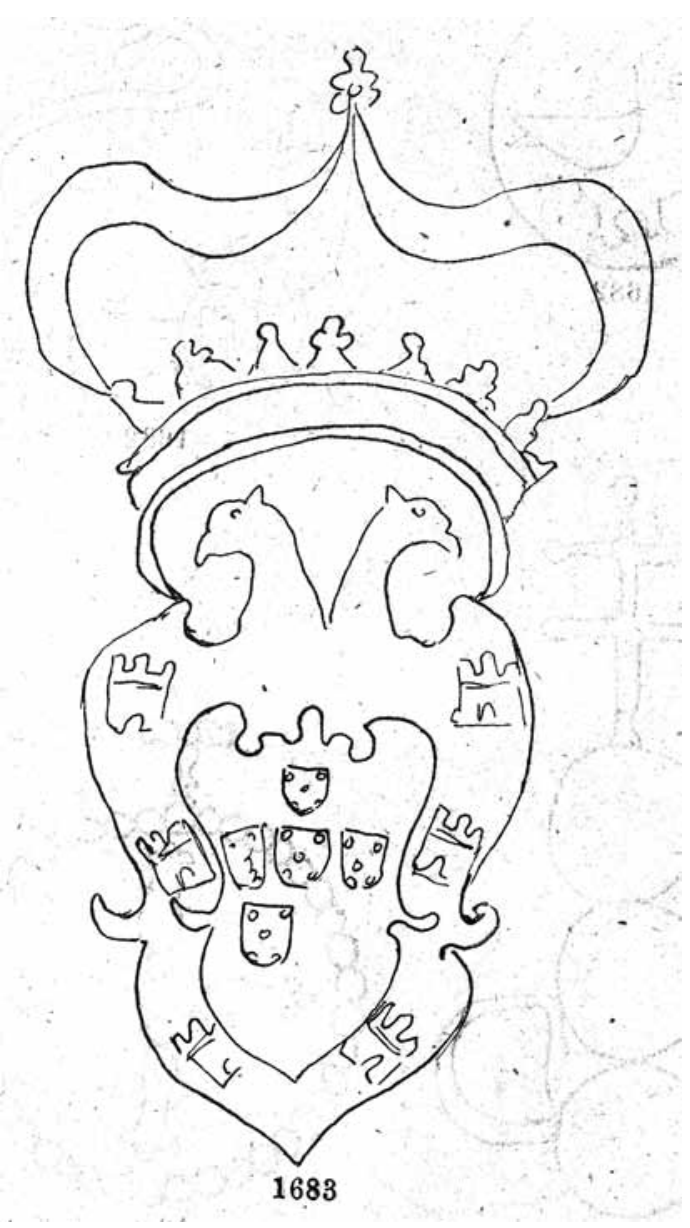

Figura 28 - As armas do reino de Portugal com a forma de águia bicéfala, marca d'água (filigrana) em papel utilizado em 1683. (Cf. João Amaral, 1949, p. 443-478).

feita é entre Lisboa e os corvos, relação que prenunciaria o futuro da cidade como capital desse "Reino do Messias", o seu segundo advento.

O sermão fala de Lisboa, a cidade cuja conquista aos árabes em 1183 foi decisiva para existir Reino de Portugal. A crônica da fundação do reino diz que D. Afonso Henriques, o conquistador e primeiro rei luso, efetuada a conquista, mandou buscar os despojos de São Vicente que estavam sepultados no Cabo (que passa a ter o nome do santo) e invocou o patrocínio do santo para a nova conquista. Nesse fato remoto via-se, no século XVIII inicial, um prenúncio do futuro Império do Mundo.

Apenas aí, nessa legenda de São Vicente e na bíblica história do profeta Elias, Vieira viu corvos aparecendo como instrumentos de Deus para alcançar seus desígnios. De resto, diz o jesuíta do "comum dos corvos", eles são vis, são maus, inferiores criaturas ${ }^{133}$. Na literatura espiritual da época, o corvo é geralmente uma figura negativa. O padre Rafael Bluteau, por exemplo, no Sermão

133. Como se lê no Sermão da Visitação de Nossa Senhora a Santa Isabel (1638), no Sermão das Exéquias do Sereníssimo Infante de Portugal Dom Duarte..., e no Sermão de São Roque (1644); ver Antônio Vieira (2001). 
134. Cf. Rafael Bluteau (1698, p. 352).

135. Cf. Padre Antônio Vieira (1957, p. 63).

136. Idem, p. 74-77.

137. Idem, p. 77-79, 274-

286.

138. Ver Centro Ernesto Soares. na Profissão de Sóror Maria da Coluna, de 1685, declina diversos epítetos negativos do corvo ("seus defeitos"), além dos mais gerais, como maligno, torpe e imundo 134 .

Nesses dois casos descritos, assume-se a representação política de Portugal como a verdadeira monarquia designada para instaurar o Império Universal de Cristo na Terra, servir à "verdadeira religião", convertendo e reformando o Mundo todo, como cabeça temporal de tal império ${ }^{135}$.

É, de fato, uma questão política a constituição de uma união das coroas (Estados) da Cristandade, esse "corpo vasto" que anda desunido, "imperfeito", conforme diz o padre Vieira, mas que constitui um "um Império espiritual". Para a realização do Reino de Cristo na Terra, impunha-se que tal corpo estivesse integrado a uma só "cabeça universal", com "supremo poder e autoridade": 136 "o Império de Cristo Consumado na Terra", dirigido por dois vicecristos - um Papa e um Rei -, para a afirmação dos preceitos católicos e expansão deles no mundo todo 137 .

Assim sendo, a presença de um escudo real entre os vereadores da primeira Câmara daquela vila deve estar ligado a movimentos políticos de teor quinto-imperial, conectando tal objeto a realidades mais amplas do que a da vila da Madalena. No caso do arquipélago dos Açores, vale ainda lembrar que sua situação geográfica o expôs a constantes ałaques dos chamados e infiéis e hereges - naus de turcos e argelinos; piratas ingleses e franceses - durante os séculos XVI, XVII e XVIII. Para se ter uma ideia, em 1714, quatro fragatas argelinas fizeram pilhagens na ltha Terceira e na do Pico. Desse modo, a afirmação da Cristandade era também questão de segurança. De acordo com a parênese messiânica da Restauração do Reino e com as teses do Quinto Império, quem atacar o país não peleja contra Portugal, senão contra a firmeza da palavra e promessas divinas.

É sabida a intensidade da tradição do Império do Divino Espírito Santo (o Paracleto) nas ithas atlânticas dos Açores. De resto, é uma tradição que se difundiu desde o século XIV por todo Portugal, alcançando posteriormente também - Brasil. Falando de Portugal, o Centro Ernesto Soares de lconografia e Simbólica (Mafra, Portugal) informa, no verbete "Império", que, passado o seu apogeu entre o século XIV e a primeira metade do XVI, a sobrevivência das ideias que constituíam o fundo da devoção do Paracleto "processou-se por intermédio do messianismo do Quinto Império, indevidamente reduzido ao Sebastianismo, o qual, para sua própria assunção e sagração, suscitou tal ambiguidade". E assinala

Disso é testemunho a convicção expressa no século XVII pelo Bispo de Porto, D. Fernando Correia de Lacerda, quando escreve: "E considerando o Império e a Candeia se é lícito ajuizar as alheias acções, principalmente estas que são misteriosas, não podemos deixar de entender que aquela candeia põe a Santa Rainha todos os anos ao Espírito Santo, para que Deus, havendo um só pastor e um só rebanho, estabeleça, em cumprimento da sua promessa, na coroa portuguesa, o império universal do mundo"138. 
Oh Reina del Mundo,

Señora del Cielo,

Puerta por quien todos

Entran al Imperio! ${ }^{139}$

Sor Juana Inés de la Cruz

A associação da Virgem com a lgreja, evidentemente, não era novidade. A novidade foi desengessar o emblema que estava relacionado à política temporal, ao Sacro-Império, ou seja, subtraí-lo e colocá-lo como paradigma da Cristandade toda, da lgreja Universal, em apoio a um programa de união da mesma Cristandade em torno de um Papa e de um rei temporal (imperador), para resolver os conflitos, entre os Estados cristãos, e os impedimentos que o imenso Império Otomano e os Berberes causavam - um mundo muçulmano que fronteava com a Europa católica desde a Polônia até a zona de Gibraltar, e que se tomado por todas as forças cristãs reunidas abriria caminho à universalização da fé católica.

Na segunda metade do século XVII, quando se projeta com força essa afirmação do poder imperial da lgreja, calcada na ação planetária das missões evangelizadoras sob auspícios das monarquias ibéricas (e, naquela altura, também promovidas pelo reino da Françal, não se tem notícia de estar circulando, no meio eclesiástico em geral, uma exposição, uma argumentação tão acabada como a do padre Vieira da Companhia de Jesus a respeito dessa finalidade universal - a da conversão e estabelecimento do Império dos Últimos Dias.

Em sua doutrina do Quinto Império, Vieira trabalha o tempo todo a associação da Virgem com a lgreja, a articulação entre as "duas naturezas" - o temporal e o espiritual, entre a Virgem/Lua e o Cristo/Sol llembremos dos versos já citados do padre Caussin: "El Aguila Imperial de dos cabeças, unida oposicion de dos grandezas"); associação esta que têm rebatimento nas figuras das vigararias temporal e espiritual destinadas a dirigir o mundo - os vice-cristos.

Na disseminação, na ostentação desse emblema - "esto es un Dios con dos naturalezas", como disse o poeta Alonso Bonilla (ver nota n. 47) - por toda a parte, nas quatro partes do Mundo, agiu poderosamente o pensamento/ ação/obra do jesuíta Antônio Vieira. A sua doutrina escatológico-messiânica, sabemos todos, circulou em sermões, cartas e textos políticos, e em conversações; teve vários nomes e foi concentrada em dois textos: a Clavis Prophetarum (Chave dos Profetas), que em português ele chama de Quinto Império ou Império Consumado de Cristo, não publicada em vida de forma acabada, limada; e a História do Futuro, publicada apenas em 1718 (Lisboa). E a novidade é a correlação que estabelece entre o futuro político da Cristandade e uma necessária consumação terrena do reino de Cristo e da Virgem, por vias de um rei e de um papa, ambos puros, ambos vigários de Cristo, a partir de uma fundamentação, como ele mesmo diz, histórica, geográfica e teológica: ${ }^{140}$ o domínio universal de Cristo deverá ser também temporal ${ }^{141}$.
140. Cf. Padre Antônio Vieira (1957, p. 51-52). Ao Cristo, diz Vieira, foi prometida pelo Pai, a salvação de toda a humanidade pela conversão, e quanto à Virgem, diz que "desde o princípio do Mundo" foi prometido que ela "quebraria a cabeça á serpente": a heresia, a infidelidade, o mal, que Vieira localiza no Império Otomano, como única força organizada com imenso poder sobre imensas regiões e populações.

141. Idem, p. 61. 
142. José Alberto Veiga Meira, apud Margarida Vieira Mendes (s..d., n. 10)

143. Cf. Padre Antônio Vieira (2003, p. 292)

144. Cf. Johannes Meier (2010, n. 2)

145. Cf. Charles Boxer (2007, p. 89).
As ideias contidas na águia bicéfala da lgreja são simétricas ao pensamento ao qual Vieira dedicou os cinquenta anos finais da sua longa vida e que construiu o grande edifício político-teológico que é a fundação de um Quinto Império ou o Império Consumado de Cristo na Terra, um império eclesiástico gerido por dois vice-cristos - um papa e um imperador - que desdobram na terra o reinado de Cristo e da Virgem no Céu, um império que irá substituir o Sacro Império existente, parcial na condução da sua política ljogando entre França e Inglaterra). É o projeto milenarista escatológico barroco da contrarreforma: uma monarquia absoluta eclesiástica, universal, em contraposição ao messianismo das grandes monarquias absolutistas.

O projeto imperial eclesiástico, de comunhão dos homens, submissão aos valores cristãos, redução dos inimigos da fé, como via de crescimento e equilíbrio do Ocidente cristão, é essencialmente de cariz jesuíta. José Alberto Veiga Meira "mostrou nas obras de Sebastião Gonçalves e Brás Viegas, dois jesuítas de começos do século XVII, que alguns padres da Companhia estavam convencidos de que pertenciam à ordem religiosa predestinada - a nova ordem que, segundo Joaquim de Fiore, desempenharia um papel decisivo na restauração da lgreja e na sexta idade do mundo"142.

A Companhia de Jesus era a grande evangelizadora dos tempos modernos, trabalhando junto ao povo e aos governantes, pregando, em militância exacerbada, o triunfo da lgreja, nas ruas e praças, nos templos, através do culto e da palavra no púlpito, da catequese em massa e da educação secundária. É dentre seus membros mais envolvidos nesses trabalhos que emerge o padre Vieira, alternando entre o imenso esforço de conversão dos povos nativos da América e o trabalho político nas cortes europeias.

O princípio da "conversão universal", eixo da ação e objetivo último, diferencia a Companhia de Jesus das demais ordens religiosas. A ação está comprometida diretamente com o fim: a conversão universal é também o compromisso se fundar, de dar base a uma monarquia universal.

Vejamos o que diz o padre Vieira a esse respeito, em sua Carta Apologética, datada de 1686: "A altíssima e principal razão [...] porque Deus há de levantar no mundo esse Império é a conversão universal do mesmo mundo por meio de sua autoridade e poder"143.

A diferença está nessa dimensão políitica de trabalhar com os grandes, com os reis, com as elites da burocracia e das letras, com a "gentilidade", no confessionário, nas visitações, dedicar-se à educação no sentido mais amplo, esse estar no mundo sem descuidar da doutrina e da reflexão, da "espiritualidade".

Revalidando o princípio geral, dando conta da sua identidade, a Companhia de Jesus tinha o lema totus mundus nostra fit habitatio lo mundo todo se converte em nossa casa) $)^{144}$. $O$ trabalho devia ser feito em toda a parte, relata o vice-rei da Índia ao rei Pedro II, na década de 1690: os jesuítas, quando "saem para as missões, eles consideram o lugar em que exercem a sua vocação como sua verdadeira pátria"145.

O sonho da unidade europeia significa, para o projeto jesuíta, a unidade da Cristandade e a conversão das "quatro partes do mundo", quando o 
Sol e Lua - Cristo e a lgreja ou, o que é o mesmo, Cristo e a Virgem, duas cabeças - em equilíbrio, reinarão, fazendo "descer o céu à terra" ou, por outro modo, "a cidade à terra": descer "não localmente, porque o céu não havia de mudar de lugar passando à terra, mas civilmente, porque a terra havia de mudar de costumes, vivendo-se na terra como no céu", diz o padre Vieira em um de seus escritos fundamentais ${ }^{146}$.

Vieira olha para Cristandade do seu tempo e a vê "dividida em tantos corpos e cabeças políticas quantos são os Reis soberanos que as governam; e dos estragos que entre eles faz a discórdia". Com isso, quem acaba sofrendo perturbações é, diz ele, a "universal lgreja". $\bigcirc$ eixo do seu programa políticoteológico é eucarístico. A felicidade e a justiça são alcançadas com a paz e a concórdia entre soberanos e entre os homens. Essa é a diretriz da lgreja le da Companhia).

A "unidade e a união da fé Católica" eram, segundo Vieira, a única maneira de vencer o que ele denomina de "Infidelidades" no mundo, divididas em heresias, judaísmo e gentilismo. Mas, sobretudo, o modo eficaz de extinguir o paganismo, onde enquadra os maometanos: as "infidelidades" deverão ser convertidas; o paganismo, extinto. Dado a força que a "Seita de Mafoma" e o Império Otomano detêm, o caso é de guerra total, extinção da "falsa fé" pela conquista e dominação dos vastos territórios que eles ocupam.

Como o Império Otomano só crescia, confrontando com o poder dos Estados cristãos, e carregava com ele a sua lei islâmica, esse turco, na visão político-messiânica de Vieira, é o anticristo, é o "maior inimigo da Lei de Cristo". E devia ser destruído o quanto antes, para que um dia não viesse a dominar o mundo com a sua "lei" 147 .

Para Vieira, a figura da "águia de três cabeças", que indica sinal de fraqueza entre os homens ${ }^{148}$, é uma antevisão do mundo do seu tempo: "o Império Romano - o Sacro, o Quarto Império - no estado de sua declinação, em que ultimamente se veio a dividir, como hoje está, em três cabeças: uma na Alemanha, que é o Imperador; outra em Roma, que é o Papa; outra em Constantinopla, que é o turco"149. Essa terceira cabeça, o turco (Império Otomano), indica para ele a presença de um poder altamente destruidor, verdadeira ameaça à Cristandade, e, pois, a evidente presença do anticristo no mundo.

$\bigcirc$ perigo era, portanto, o Império de Mafoma dominar o mundo. Pelo contrário, pondera o jesuíta, se algum dos príncipes (governantes) pelos quais "está dividido o antigo Império Romano [...] dominasse a Europa e o Mundo", isto não seria problema porque não seriam mudados "os tempos nem as Leis". Além do mais, somente esse único monarca universal e o papa poderiam vencer os inimigos da fé e implantar o Quinto Império, quando - e ele o diz claramente - a águia de duas cabeças substituirá a "águia de três cabeças" que aparece no livro de Esdras.

Eliminada do mundo a "Seita de Maomé", o Império Cristão poderia ressurgir com as duas cabeças - o Corpo Místico de Cristo -, numa demonstração de "unidade e a união da fé Católica", única maneira de se concretizar a Cristandade, a paz universal, a felicidade, estendendo o Reino de Cristo, sua
146. Ver Padre Antônio Vieira (1965b).

147. Cf. Padre Antônio Vieira (1957, p. 10-11).

148. Ver 4 Esdras (11-12) (apócrifos, Ezra).

149. Cf. Padre Antônio Vieira (1957, p. 15). 
150. "Os Franceses em particular dizem que há de ser o rei de França"; cf. Padre Antônio Vieira (1957, p. 261).

151. Foi declarado Doutor da Igreja pela Santa Sé em 1722.

152. Cf. Padre Antônio Vieira (1957, p. 262).

153. Cf. Padre Antônio Vieira (1949, p. 246).

154. Para alguns Estados, meta de interesse mais direto, $\mathrm{e}$ para outros, não, como era o caso da França, sem que se esqueça o crescente e promissor comércio atlântico que superara o do Mediterrâneo.

155. Cf. Padre Antônio Vieira (2003, p. 291-292).
Igreja, a "verdadeira fé" no mundo inteiro. A teoria do Quinto Império é tanto um coroamento como a própria justificativa da criação da Companhia de Jesus e de sua prática, espalhada pelo mundo inteiro como milícia avançada de Cristo para converter a todos, especialmente nas partes mais remotas com infinita gente.

Quem seria esse príncipe da Europa a converter-se em monarca universal? Esse era o problema. O monarca francês queria a Monarquia Universal da Cristandade, declara Vieira na sua Defesa perante o tribunal do Santo Ofício ${ }^{150}$. Mas acrescenta que "a comum opinião de quase todas as nações da Europa - naqueles meados do século XVII - é que este esperado Imperador há de ser príncipe de Espanha, e que a Espanha há de ser o assento do seu Império e Monarquia - assim o dizem e supõem as profecias de Santo Isidoro [de Sevilha $(560-636)]^{\prime \prime} 151$.

Os escritos da primeira metade do século XVII de "Jerônimo Vechietto, Tico Brahe, Kepler Justo Lypsio e outros autores" também indicavam que o "Rei encoberto e fatal de quem e a quem promete tantas maravilhas e felicidades" teria o seu assento no Ocidente. Quanto a isso, o pregador jesuíta não deixa de assinalar que esses autores eram interessados na monarquia espanhola, "porque uns são flamengos, outros alemães, outros italianos" ${ }^{\prime 152}$.

Vieira vai tentar convencer a toda a gente, através de suas cartas e textos político-teológicos, que esse "Rei encoberto e fatal" será português. Argumenta que, dentre os reinos cristãos, Portugal era o que andava envolvido em infinitos e maciços trabalhos de conversão, especialmente nas Conquistas do Brasil. E, sendo um reino tão pequeno - "quatro palmos de terra que Deus nos concedeu na Europa"153 - conforme diz, que o Imperador Universal tivesse ali assento não oferecia risco às potências, quanto mais que os soberanos portugueses estavam ligados familiarmente a todos os grandes monarcas. Além disso, segundo a tradição, o reino de Portugal teria sido escolhido pelo próprio Cristo, iá no ato de fundação (1 147), para ser seu futuro Império, segundo o Milagre de Ourique.

Vieira cria, assim, uma opção para os ajustes entre Estados em conflito de interesses e outra para a expansão e enriquecimento deles: a conquista partilhada do imenso território dos muçulmanos ${ }^{154}$. Seria uma escolha dos demais soberanos a adesão a um Imperador português e ao Papa a ele unido.

Mais ainda. Essa atitude universalista de Vieira fica registrada em sua Carta Apologética datada de 1686 - "É coisa universal", assim se defende o padre Vieira em carta ao padre Jacome lquazafigo, Provincial da Companhia de Jesus na Andaluzia. Em 1757, a longa carta foi editada em Lisboa por um padre secular, com o título Ecco das Vozes saudosas formado em huma carta apologética...

Agora folgara eu muito saber de nosso Escoto Patavino [pseudônimo de um dominicano espanhol] que é o que the descontenta em um Imperador cristão que o seja de todo o mundo? Se não o quer Português, como dizem muitos dos autores citados; se the desagrada por ser Espanhol, faça-o Escocês, como ele se faz, tomando-se o nome de Escoto; ou ltaliano, como Patavino, de quem tomou o sobrenome, que isso não é mais que questão de vocábulo: o que certamente importa pouco, contanto logre a lgreja um Império de todo o mundo, estabelecido em um Príncipe Católico e súdito do Romano Pontífice ${ }^{155}$. 
A águia de duas cabeças representa, portanto, um projeto e um programa a cumprir, cujo primeiro ato seria unificar a Cristandade em torno da ação contra o Islã, sob o cetro da lgreja e de um monarca comandante dessa ação. Conta Vieira que, modernamente, o irmão Alonso Rodrigues, um religioso da Companhia de Jesus, estando em uma das ilhas do Mediterrâneo, tivera uma visão que mostrava a conquista do Império Otomano: viu a armada dessa conquista "em que na Capitânia ia Cristo, e na Almiranta, a Virgem Santíssima" ${ }^{156}$.

Um projeto e um programa a cumprir, não sem grandes esforços, pois "algumas das paredes deste universal edifício - o mundo universalmente convertido à lgreja de Cristo - estão ainda por levantar, que são todas as nações de Infiéis, que estão para converter, e outras que já estiveram levantadas e edificadas, estão arruinadas e caídas, que são as de tantos reinos e nações de cismáticos e hereges, as quais também se hão de reduzir" 157.

Pensamento de Vieira é a lgreja Militante a clarear a sua meta, seu fim, e os caminhos para alcançá-la. Milícia maior de Cristo, como se pretendia, a Companhia de Jesus, até por isso mesmo não poderia excluir a adesão de todos - o que incluía outras ordens religiosas - aos objetivos então traçados e esmiuçados. Por isso, observa o seu arauto, que "é certo que Deus ama mais a sua lgreja Universal que as congregações particulares dela"158.

Desse modo, acreditar na força da lgreja, no poder de Cristo acima de tudo, é, no tempo, aderir a essas ideias e ao seu emblema: a águia bicéfala coroada com a coroa imperial, desembaraçada dos escudos heráldicos, das insígnias dinásticas, de atributos particulares.

Eis a novidade dessa águia, que é retomada, reintroduzida como símbolo da monarquia universal por vir, uma construção do século XVII que se dissemina de modo significativo a partir da segunda metade daquele século, concomitante ao desenvolvimento da teoria do Quinto Império pela voz e a escrita do padre Antônio Vieira.

Por ele considerar as questões candentes do tempo - políticas, religiosas e econômicas -, seus textos medraram em terreno fértil. A propagação de suas ideias teve um instrumento eficaz na formidável máquina internacional representada pela Companhia de Jesus. Seus textos alcançaram afeiçoados e, além de Portugal, houve até um relativo sucesso na ltália e na Espanha dos anos de 1660. Na década anterior ele já os submetia a teólogos e doutos pertencentes, ou não, à Companhia. Comunicou seus pensamentos "com os mais doutos Teólogos e escriturários" da sua religião na Europa e, conforme diz, "todos

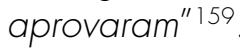

A biografia de Vieira registra que as suas teses impressionaram o Papa e vários cardeais do Sacro Colégio ${ }^{160}$. Associado a esse fato, também consta de sua biografia que, no início da década de 1670 (quando o jesuíta já estava em Roma), o Turco (Império Otomano) havia "alcançado certas vitórias contra a Polônia, por onde ficava com a porta aberta para a Hungria e Alemanha, e daí para a Itália". De fato, Vieira constantemente indica as fragilidades e o declínio do grande Império Romano dos tempos de Carlos V,
156. Cf. Padre Antônio Vieira (1957, p. 16).

157. Idem, p. 41.

158. Idem, p. 192.

159. Cf. Alcir Pécora (1994, p. 291); grifo meu.

160. Cf. João Francisco Lisboa $(1956$, p. 228). 
161. Idem, p. 202.

162. Cf. Alcir Pécora (1994, p. 224).

163. Cf. João Francisco Marques (1989, p. 303, n. 14).

164. Idem, p. 238.

165. Idem, p. 177.

166. Idem, p. 306, n. 44

167. Idem, p. 187. pelo que já os astrólogos deste último país não o asseguravam da invasão iminente. Com isto já havia grandes cuidados em Roma e não faltavam grandes cabeças que punham os olhos em Portugal, como lugar muito próprio e seguro para asilo do Papa. Semelhante acidente faria mudar a cena em toda a Europa ${ }^{161}$.

Em 1641, Vieira deixara a Bahia e chegara a Portugal provido não só de fama, mas convicto de suas ideias messiânicas, escatológicas, o que, na capital do reino, no contato com outros jesuítas, logo só fez reforçar. E a sua vocação estava "acompanhada de muita gente a seu tempo. Pelo que é dado saber, quando ele chega a Portugal, em 1641, encontra o país em verdadeira efervescência visionária"162, para a qual confluía o messianismo sebastianista e uma situação muito especial, de ressurgimento, de restauração do Reino diante da Coroa espanhola, situação aparentemente inexequível, mas que acabava de acontecer e seria preciso garantir a qualquer preço.

É importante notar que não só os padres da Companhia de Jesus, mas padres seculares e religiosos de outras congregações participavam da efervescência visionária, fato evidenciado pela tese do historiador português João Francisco Marques sobre a Parenética Portuguesa e a Restauração. No púlpito, religiosos coetâneos de Vieira, jesuítas ou não, "teorizavam os sucessos, interpretavam o devir, na arquitetura dos seus sermões"163. $\bigcirc$ profetismo e o maravilhoso estruturavam o sermonário restauracionista ${ }^{164}$. Religiosos oratorianos, teatinos, trinos, carmelitas, cistercienses, beneditinos e franciscanos, entre outros, falavam do "Encoberto". Frei Roque de Soveral, da Ordem de Cristo, em sermão pronunciado em Tomar, em 1641, antevê em D. João IV, o Restaurador, o rei português que, apoiando um pé em Portugal e outro na Espanha, irá tornar-se o maior monarca, o de maior domínios, sendo assim "do mundo todo Imperador"165.

Em Portugal, Vieira fez amigos entre a nobreza e o clero. Fez prosélitos entre os dirigentes da Restauração. Como ele mesmo informa, não só o vulgo venerava e lia Bandarra ${ }^{166}$, em cujas trovas quinhentistas o mito do quinto e último Império de Cristo na Terra tinha abrigo. E "desde há muito que franciscanos e alcobacenses (Ordem de Cister) portugueses se mostravam sensíveis às influências do doutrinarismo joaquimita"167, que lia nas profecias de Daniel a vinda de um Imperador do Mundo e um Papa Angélico.

As mais diversas pessoas eram afetadas pelo seu "engenho e arte". $\bigcirc$ mito imperialista afeiçoava a muitos. As notícias que se têm de suas perorações públicas são de que ouvintes enchiam não só o interior como o adro das igrejas, tanto em sua primeira estadia em Portugal (1641 a 1652), como em seu retorno ao Reino (1675-1681), depois da sua prisão pelo Santo Ofício (1663-1667), acusado de judaísmo nas suas proposições político-teológicas, e posterior exílio na Itália (1669-1675). O entusiasmo do público por Vieira nunca esmoreceu. Veja-se, por exemplo, o caso do padre teatino Rafael Bluteau, Qualificador do santo Ofício e censor designado para leitura do livro Rosa Mística, reunião de sermões rosarianos preparada por Vieira em 1684. Bluteau, em 1685, termina a sua censura assim: 
Desmente, pois, esta obra as obras da natureza, porque, sendo cada folha deste livro uma rosa, não há em todas estas rosas um espinho. Bem pudera o autor ter escrúpulo de dar aos entendimentos tanto gosto, mas quero supor que não ignora que a piedade, com que se ensina, canoniza a elegância com que se escreve. Porém, tão fora estou de o poder desculpar, que é forçoso que o torne a arguir de dois crimes: da inveja que do seu talento toda a Europa tem a Portugal, e da desesperação em que mete os oradores de poder imitar o seu estilo. E ainda assim entendo que é justo que, sem descanso e sem limite, corra o parto de um engenho que tanto voa.

Este é o meu sentir. Vossa Senhoria llustríssima ordenará o que the parecer mais conveniente ${ }^{168}$.

Se, por um lado, pela suas ideias, houve afrontamentos públicos a ele em Portugal (Évora, em 1675, e Universidade de Coimbra, em 1682, onde queimaram uma imagem sua), no México era admirado tanto por oponentes, como Sóror Juana de La Cruz, como por prosélitos, como os que, na Universidade, estamparam sua imagem em livro e dedicaram-lhe "umas conclusões de toda a teologia"169. Na portada do livro aparecia seu retrato, rodeado das insígnias dos triunfadores: as palmas, as trombetas e a ave Fênix.

A Companhia de Jesus era poderosa no México. Entre 1662 a 1678, parte de seus sermões estava traduzida para o castelhano. Em 1685, era editado na cidade do México, traduzido do italiano, o opúsculo Lágrimas de Heráclito defendidas em Roma pelo Padre Antônio Vieira contra o riso de Demócrito, em $1674^{170}$.

Seja como for, a qualidade, a abundância e a amplitude geográfica com que a figura da águia bicéfala quinto-imperial se disseminou nas décadas de 1670-1690 indicam a fortuna dessas ideias proclamando o advento de uma nova ordem de paz e felicidade no mundo.

$\bigcirc$ projeto escatológico-messiânico do padre Vieira le também a literatura profética portuguesa de fins do Seiscentos) não deve, portanto, ser menosprezado, ou circunscrito à retórica, tanto quanto não deve ser negligenciada a literatura profético-messiânica espanhola e francesa (paralela à diplomacia dessas nações), que, no século XVII, elabora o pensamento do Imperium em nome de seus Estados, sempre substituindo Viena pelas suas capitais: tudo isso é resposta absolutista ${ }^{171}$.

A França de Luís XIII e, especialmente, a de Luís XIV, de Richelieu e de Mazarino era o Estado em maior ascensão econômica e militar do Seiscentos. Também ela se atribuía a eleição providencial para árbitro da Europa e ruína dos turcos: uma versão do Império do Mundo, de raízes joaquimitas ${ }^{172}$. Os franceses se candidatam ao Império no século XVII, afirmando o "orbis terrarum" 173 como seu patrimônio dinástico. Esse messianismo político reforça, no Reino de França, a coesão nacional.

Os primeiros sucessos do reinado de Luís XIV (1656-1700) "são interpretados como sinais de realização iminente da monarquia universal" 174 . A literatura messiânica produzida nesse reino forçosamente se vale dos sinais dos astros e das profecias bíblicas. As "Influências Celestes", que englobavam a campo da astronomia e astrologia, não estariam ausentes da reconstituição do passado, das interpretações do presente e dos prognósticos do futuro do Reino.
168. Cf. Padre Antônio Vieira (1965a); grifo meu.

169. Cf. Padre Antônio Vieira (2003, p. 313).

170. A tradução em português foi realizada pelo 4 . Conde de Ericeira e incluída nos Sermões.

171. Cf. Jean-Marie Apostolidès (1993 p. 61-83). Falando da literatura mitistórica, Apostolidès observa que a sua forma vulgarizada, que circula sob o olhar complacente do Estado e muitas vezes é sucitada por ele, não deve ser neglicenciada pela historiografia, por mais delirantes que tais obras possam parecer; idem, p. 67.

172. Segundo ele, "a mitistória pode ser definida como uma totalidade concreta, laica e política, cuja existência está ligada à forma monárquica do Estado, e que ocupa a posição central do discurso religioso na Idade Média. Se as crenças cristãs já não são o código através do qual se exprime o real no século XVII, nem por isso desaparecem. Sobrevivem enxertando-se na árvore mitistórica. Assim, o imperium utiliza às vezes o código religioso para exprimir-se. Toma então a forma de uma reivindicação messiânica mesclada de toques apocalípticos"; idem, p. 75.

173. Idem, p. 61-65.

174. Idem, p. 69. 
175. Ver Jacques Halbronn (s. d.).
As especulações astrológicas ainda eram objeto de grande interesse. Em 1660, os embaixadores da Inglaterra e da Espanha alarmaram-se com profecias feitas contra suas respectivas pátrias e apresentaram um pleito contra o autor do livro Fatum Universi, que tinha como nome de autor Petrus Allaeus, árabe cristão ${ }^{175}$.

Na Europa, a segunda metade do Seiscentos inicia-se no rescaldo da devastadora Guerra dos 30 Anos, onde mediram forças os dois grandes pretendentes a uma Monarquia Universal: o Rei Cristianíssimo (França) e o Imperador dos Romanos (Alemanha). A monarquia católica de Espanha também lançava vistas para um domínio universal.

Terminada a guerra trintenária em 1648, instaura-se desde então um tenso equilíbrio, que parece temer apenas o avanço dos Otomanos nas fronteiras orientais da Cristandade. Se, na época, o projeto da Monarquia Universal é considerado por muitos uma quimera, o da Companhia de Jesus se crê pleno de possibilidades - fatos políticos se confundem com os desígnios da Providência: a instauração do Império Universal de Cristo na terra, baseado na unidade da fé e na conversão universal dos homens, na lgreja irmanada com um monarca fruto de uma escolha profética, um desígnio particular do Cristo.

A partir de 1660, as pressões do Império Otomano avançando sobre - Sacro Império Romano só insuflam o espírito triunfante da igreja contrarreformista e estimulam os agentes e os afeiçoados da via moderna do Império de Cristo, traduzindo-se na afirmação dos Mistérios e do Poder da Virgem.

Se à Imaculada Conceição da Virgem, o dogma central da catolicidade, em pleno tempo do Barroco são consagrados dois reinos como a França (1638) e Portugal (1646) que se pretendem afirmar, um como supremacia, como árbitro da Europa, o outro como reino redivivo e se a monarquia espanhola tem a Imaculada como padroeira de sua infantaria militar, conquistadora de Flandres, o projeto eclesiástico milenarista vai além dessa particularidade do dogma, daí aterse aos Mistérios da Fé, ao Rosário, para simbolizar a universalidade do Corpo Místico de Cristo e seu último e consumado império na terra.

A defesa da lgreja, por parte das cabeças coroadas, circunscrevia-se à defesa da Fé Católica contra Estados e facções heréticas ao credo do Vaticano. Mais do que tudo, os reis afirmavam a sua legitimidade como parte do corpo da Cristandade e a grandeza do seu poder, colocando-se como defensores do dogma da imaculada concepção de Maria Mãe de Deus, negado pelos reformistas, sacralizando a sua política. Assim é com o Imperador do Sacro Império, com o Rei de França, em 1638, quando consagrou solene e oficialmente a ela o seu reinado. $\bigcirc$ mesmo faz a monarquia portuguesa em 1646 - a França, querendo para si os direitos do Sacro Império; Portugal, querendo para si o direito de existir, além de manter e expandir as suas distantes e imensas conquistas.

Fez parte da estratégia de Vieira incrementar, através da Companhia, a devoção ao Rosário, a instrução dos mistérios da fé - não sem reclamações dos dominicanos, seus primeiros e tradicionais propagadores. No Maranhão, como provincial dos jesuítas, Vieira institui a reza do Terço do Rosário a coros, todas as tardes, como se praticava na lgreja de São Domingos de Lisboa e em 
outras igrejas da Corte. Isso acontecia também em Roma, na casa professa dos jesuítas ${ }^{176}$. No Maranhão, a prática estendeu-se inclusive ao âmbito doméstico.

No púlpito, instituiu a pregação de um exemplo do Rosário aos sábados, a cada meia hora ${ }^{177}$. Fez tornarem-se prática corrente as rezas a bordo dos navios portugueses: isso teve início em uma viagem de Lisboa ao Brasil, no ano de 1653, quando Vieira estimulou a tripulação e passageiros da caravela a rezar o terço do Rosário todos os dias enquanto durou a travessia ${ }^{178}$. Os seus sermões do Rosário, pregados no Maranhão, Brasil, datam dessa época (1654), e foram então divulgados, mas a edição supervisionada por Vieira só ocorreu em Lisboa no ano de 1686 (a segunda parte foi editada em 1688).

A legenda da Ordem Dominicana, iniciadora do culto ao Rosário no século XIII'179, é contada pelo padre Vieira: na visão de São Domingos de Gusmão, o Cristo Juiz, irado, queria "fulminar o mundo" e, segundo entendeu o santo, as causas eram "aqueles três vícios entre os capitais capitalíssimos: soberba, cobiça, sensualidade". A Virgem, a Mãe de Misericórdia consegue que revogue a sentença por ter de proteger o sangue do qual ele proviera, e que ela mesma, a Senhora, "tomava por sua conta a reforma e emenda do mesmo mundo" dos pecados e maldades, da ofensa e desprezo das leis divinas ${ }^{180}$. E seria pela difusão da oração do seu Rosário.

Os dois livros de sermões que Vieira fez publicar em 1686 e 1688 sob o título de Maria Rosa Mística, reunindo 30 sermões, foram objeto de uma dissertação de mestrado na área de Literatura Portuguesa, apresentada à Faculdade de Filosofia da Universidade Católica de Braga, em 1998, por Carlos Alberto de Seixas Maduro sob o título Um sermonário mariano de Vieira: Maria Rosa Mística ${ }^{181}$. $\bigcirc$ autor nota a relevância que o sermonário do Rosário tem em Vieira, e pensa que não é exagero afirmar "que a elaboração da Rosa Mística seria um dos seus últimos propósitos e o coroar" de toda a sua obra parenética. Entretanto, desvincula esses sermões do Vieira visionário do Quinto Império.

Alcir Pécora já tem mostrado, em importante estudo publicado em 1994, a "unidade teológica-retórico-política dos sermões de Antônio Vieira" 182. $\bigcirc$ autor visualiza essa unidade muito justamente no papel nuclear que a figura sacramental ocupa na retórica de Vieira ${ }^{183}$. O discurso de Vieira, indo na direção mesma do labor exercido pela Companhia de Jesus no mundo todo como "Exército de Cristo", tem o intuito de readequar, na linha contrarreformista, a figura sacramental (o dogma do Santíssimo Sacramento, a presença do Cristo), apresentando-a "como nexo fundamental do discurso cristão da existência", emblematizando-a. Aí a custódia ou ostensório é o objeto-chave "do cerimonial repudiado pelos reformistas" 184 .

Mas, se levarmos em conta os sermões do Rosário (como $\bigcirc$ Santíssimo Sacramento Exposto, comentado anteriormente) e todo o implemento que o jesuíta dá à devoção do mesmo Rosário e mais seus escritos políticos, veremos que Vieira emblematiza a figura sacramental não apenas no sentido religioso, eclesiástico: emblematiza o Santíssimo Sacramento também no sentido político-teológico, identificando-a com a união do humano e o divino, o Corpo Místico de Cristo, numa totalidade representada pelo Rosário da Virgem la comparação da
176. Vieira se defende por estimular devoções com canto público dizendo que também em Roma se fazem "semelhantes devoções [...] nas sextas-feiras e nos sábados" na casa professa dos jesuítas com grande aprovação e sucesso entre os fiéis"; cf. Padre Antônio Vieira (2003).

177. Idem, p. 114.

178. Idem, p. 92. Nos domingos e dias santos seriam em voz alta e coros.

179. Como informa Carlos Alberto de Seixas Maduro (1998), foi "o bretão Frei Alano da Rocha (1426-1475), professor de Teologia e pregador, que, ao escrever o célebre livro Psalterium Mariae Virginis, obra de muito êxito mas também de pretexto para graves confusões e deturpações, criará a verdadeira tradição da devoção mariana do Rosário". Ver nota 42 do aludido estudo.

180. Padre Antônio Vieira apud Carlos Alberto de Seixas Maduro (1998, n. 48).

181. Ver Carlos Alberto de Seixas Maduro (1998).

182. Ver Alcir Pécora (1994).

183. Idem, p. 64 e 263-264.

184. Idem, p. 264 
185. Cf. Anne-Laure Angoulvent (1996, p. 100)

186. Cf. Francis Haskell (1997, p. 148)

187. Cf. Giulio Carlo Argan (1999, p. 262). "devoção do Rosário com a de toda a lgreja"), peça-chave da ação prática, política, isto é, concentra na lgreja o verdadeiro poder não só celeste, espiritual, como também terrenal, com vistas a um Estado católico universal, um Quinto Império de Cristo Consumado na Terra: a águia de duas cabeças.

Assim foi a época e a epopeia do padre Vieira. Época em que eclodiu um barroco triunfante e imperial, adentrando tardiamente no século XVIII, através da Europa central. Em Portugal, os ecos das profecias do Quinto Império também chegaram até as três primeiras décadas do Setecentos. De resto, a conjuntura do novo século apontava para o fenecimento dessa ideia imperial, impregnada de elementos teológicos: são balizas seguras disso a paz de Utrecht (1713) e a aliança franco-anglo-espanhola (1717), além da ascensão da Prússia e da renúncia de Filipe V de Espanha a aspirante da coroa de França (1720).

O século XVII foi o do "renascimento radical católico", onde a Companhia de Jesus trabalhou arduamente ad majorem Dei gloriam. Bernini, nas artes, foi o porta-voz desse renascimento, de tal modo sua arte "está ligada à história da evolução religiosa que abala a Europa dessa época"185. Segundo Haskell, a emoção que esse artista coloca na obra da lgreja da Sant'Andrea (Roma, 1658), da Companhia de Jesus, a cujos ideais era afeiçoado, é tamanha, que "pulveriza as barreiras arquitetônicas tradicionais para fundir o Céu e a Terra numa única unidade" 186.

De acordo com a ideologia católica pós-Trento, assinala Giulio Argan, "a cultura é uma via de salvação, porém toda a humanidade deve salvar-se, e não só os doutos. É preciso que a cultura penetre em todos os estratos da sociedade"187. Toda a atividade humana deve orientar-se ad majorem Dei gloriam, por uma solução de paz, de felicidade, de salvação eterna. Não era essa a divisa máxima da Companhia de Jesus? Mas, ainda aí, estavam indissoluvelmente ligados o discurso do poder e a guerra: o "Exército de Cristo" contra o Império que não é o do Cristo (mundo muçulmano), fazendo a guerra pela paz, uniformizando o mundo.

\section{REFERÊNCIAS}

AMARAL, Aracy. A Hispanidade em São Paulo. São Paulo: Nobel;Edusp, 1981.

AMARAL, João. Marcas de água (filigranas) de papéis do século XVII, descobertas e desenhadas por João Amaral: Beira Alta, v. VIII, fasc. IV. Viseu: Arquivo Provincial, 1949. p. 443-478.

ANASTASIA, Carla Maria Junho. Vassalos e rebeldes: violência coletiva nas Minas na primeira metade do século XVIII.Belo Horizonte: C/ Arte, 1998.

ANGOULVENT, Anne-Laure. O Barroco. Lisboa: Europa-América, 1996.

APOSTOLIDÈS, Jean-Marie. O rei-máquina: espetáculo e política no tempo de Luís XIV. Rio de Janeiro: José Olympio; Brasília, DF: Edunb, 1993. 
ARGAN, Giulio Carlo. Renacimiento y Barroco: II. De Miguel Ángel a Tiépolo. Madrid: Akal, 1999.

ARMENDARIZ, Sebastian de. Descripcion de las plazas de ambas Ungrias, y la Croacia, conquistadas por las armas Cesareas desde el Año de 1683. Hasta todo el de 86. Al primer Apostol del Japon y segundo Pablo. Ao primer compañero de S. Ignacio, y segundo Josué. Al Martyr por deseo. Al protector de las huestes christianas, y especialmente de las Austriacas. Al que tuvo dominio sobre la muerte, y cuyos preceptos obedecieron no solo las Aguas y el Ayre; pero respeto el Fuego, y la tierra. Al Portento de la Gracia. Al honor no solo de Navarra, pero de España, y de la Iglesia. Al santo de los milagres por autonomasia. Y al Apostol del Oriente por excelencia, San Francisco Xavier, ofrece, y consagra esta descripcion de las Plazas restauradas al gremio de la Iglesia, y dominio del Catolicissimo Cesar Leopoldo Ignacio, su Devoto, y Paysano, Sebastian de Armendariz. Librero de Camara de su Magestad, y Curial de Roma. 1683.

Descripcion de las plazas que possee el turco, assi en la Ungria, como en la Esclavonia, en el principio deste año de 1687. A la Emperatriz del Orbe todo y Reyna especial de Ungria. A la protectora del Christianismo contra los Otomanos, y señaladamente inclinada à los Austriacos. A la Valiente y Animosa Judith. A la que antes en varios tiempos dio muchas Palmas à los Exercitos Christianos. Y a la que aora en uno les gano varias, y grandes victorias. A la que coronada de doze estrellas representa quatro Reynos triplicados por las tres Imperiales Coronas. Y la que com milagrosa proteccion assistio à Leopoldo Augusto para ceñir pacificamente las de Ungria, Bohemia, Croacia, y Esclavonia. A la antemural de Austria, y el Christianismo, Gran Señora de Ungria. A la aguila misteriosa del Apocalypsis, y tambien de lo Imperio Christiano. Y a la que descarga el golpe sobre el barbaro orgullo, Maria Santissima en su Concepcion, remunerando la devocion Austriaca com victorias. Sebastian de Armendariz, su humilde Siervo, ofrece, y consagr.a este corto trabajo. 1687 .

ARMITAGE, David (org.). Theories of Empire, 1450-1800. Cambridge: Harvard University, 1998.

The Ideological Origins of the British Empire. Cambridge: Harvard University, 2000.

ASENSIO, Eugenio. Introdução. In: LEÃO, D. Gaspar. Desengano de Perdidos. Coimbra: Universidade de Coimbra, Acta Universitatis Conimbrigensis, 1958.

ATALLAH, Claudia Cristina Azeredo. Centro e periferias no império português: uma discussão sobre as relações de poder nas minas coloniais. Outros Tempos (Dossiê Escravidão), São Luís, v. 6, n. 8, dez. 2009. Disponível em: http://www.outrostempos.uema.br/vol.6.8.pdf/Claudia\%20 Cristina\%20Atallah.pdf.

AYUNTAMIENT DE SANTA EULÀRIA DES RIU. Joyas de Mujer. Disponível em: <http://www. santaeulariadesriu.com/ver.asp? $\mathrm{Id}=406>$.

AYUNTAMIENTO DE VALTAJEROS. Arte y Historia. Disponível em: <http://www.valtajeros.es/ index.php/mod.pags/mem.detalle/id.6/relcategoria.1024/relmenu.178>.

AZEVEDO, Edé́lson M. de. Minas Insurgente: conflitos e confrontos no século XVIII. 2006. 220 f. Dissertação (Mestrado em História) - Programa de Pós-Graduação em História, Universidade Federal de Uberlândia, Uberlândia, 2006.

BAZIN, Germain. Architecture Religieuse Baroque au Brèsil, 2. Paris: Plon, 1957. $\overline{1983 .}$

Arquitetura religiosa barroca no Brasil. Trad. Glória Lúcia Nunes. Rio de Janeiro: Record,

Annals of Museu Paulista. v. 18. n.2. July.-Dec. 2010. 
BLUTEAU, Rafael. Primicias evangelicas ou Sermoens, e panegyricos. Lisboa: Joao Anisson, 1698.

BONILLA, Alonso de. Nombres y atributos de la impecable siempre Virgen Maria ... en octauas: con otras rimas a diuersos assumptos y glossas dificiles. Madri: Pedro de la Cuesta, 1624.

BOSBACH, Franz. Monarchia universalis: storia di un concetto cardine della politica europea (secoli XVI-XVIII). Milano: Vita e Pensiero, 1998.

BOUZINEB, Hossain. Los moriscos en Marruecos durante la época de Felipe II. In: BELENGUER CEBRIÁ, Ernesto (Org.). Felipe II y el Mediterráneo: los recursos humanos y materiales, 2. Barcelona: Sociedad Estatal para la Conmemoración de los Centenarios de Felipe II y Carlos V, 1998. p. 611-623.

BOXER, Charles. A Igreja Militante e a Expansão Ibérica: 1440-1770. São Paulo: Companhia das Letras, 2007.

BUENO, Alexei; TELLES, Augusto da Silva; CAVALCANTI, Lauro. O patrimônio construído: as 100 mais belas edificações do Brasil. Rio de Janeiro: Capivara, 2002.

BUNES, Miguel Ángel de. Los Barbarroja: corsarios del Mediterráneo. Madri: Aldebarán, 2004.

BURKE, Peter. Eyewitnessing. The Uses of Images as Historical Evidence. Ithaca: Cornell University Press, 2001.

Testemunha ocular: bistória e imagem. Bauru: Edusc, 2004.

CABRERA, Frei Antonio de (O.F.M.). Glorias de El Señor D. Felipe Quinto, rey de las Españas, y Emperador del Nuevo Mundo ... y fatales consequencias, que manifiesta futuras la segunda parte de la Epístola ... Sale a luz a instancias y noble generosidad del Señor Don Bartolomé Ruiz Contreras... Madri: Francisco Antonio de Villa-Diego, 1708. Disponível em: <http://books.google. es/books?id=yRBPJThUtEC\&dq=Glorias+de+...+Felipe+Quinto, + rey+de+las+Espa $\%$ C3\%B1as+... $+\mathrm{y}+$ fatales+consequencias\&source $=$ gbs_navlinks_s $>$.

CANTI, Tilde. O móvel no Brasil: origens, evolução e características. Rio de Janeiro: Candido Guinle de Paula Machado, 1980.

CASTAGNA, Paulo. A música portuguesa na época de Antônio Vieira. In: FURTADO, Joacyr Pereira (Org.). Antônio Vieira, o imperador do púlpito. São Paulo: Instituto de Estudos Brasileiros-USP, 1999 (Cadernos do IEB).

CASTELO BRANCO, Anselmo Caetano de Abreu Gus mão de. Oraculo Prophetico, Prolegomeno da Teratologia, ou Historia Prodigiosa. Lisboa: Maurício Vicente de Almeida, 1733. Disponível em: <http://www.cesdies.net/monumento-de-mafra-virtual/oraculo-profetico $>$.

CATÃO, Leandro Pena. Inconfidências, jesuítas e redes clientelares nas Minas Gerais. In: VILLALTA, Luiz Carlos; RESENDE, Maria Efigênia Lage de. História de Minas Gerais: As Minas setecentistas. Belo Horizonte: Autêntica, 2007a.

As andanças dos jesuítas pelas Minas Gerais: uma análise da presença e atuação da Companhia de Jesus até sua expulsão (1759). Horizonte, Belo Horizonte, v. 6, n. 11, p. 127-150, dez. 2007b. Disponível em: <http://www.pucminas.br/documentos/horizonte_11_andancas_ jesuitas.pdf?>. 
CAUSSIN, Padre Nicolas, S. J. La Corte divina, o Palacio celestial. Madri: Alonso Balvas, 1726.

CENTRO ERNESTO SOARES. Consultoria-Império. Disponível em <www.emportugal.com/>.

COSTA, Lúcio. A arquitetura dos Jesuítas no Brasil (1941). In: Arquitetura Religiosa. São

Paulo: FAU-USP; MEC-IPHAN, 1978 (textos escolhidos da Revista do Instituto do Patrimônio Histórico e Artístico Nacional, 6).

DE LA CRUZ, Sor Juana Inés. O Domina Coeli.... Obras completas de Sor Juana Inés de la Cruz,2: villancicos y letras sacras. México: Fondo de Cultura Económica, 1994. p. 463.

DIAS, Frei Nicolau. Livro do Rosário de Nossa Senbora (1573). Edição fac-similar. Lisboa: Biblioteca Nacional, 1982.

DIAS, Pedro. História da Arte Portuguesa no Mundo (1415-1822): O Espaço do Índico. Lisboa: Círculo de Leitores, 1998.

EPALZA, Míkel de. Los moriscos antes y después de la expulsión. Madri: Mapfre, 1994.

Moriscos contra Carlos V: Argel y el nuevo modelo de inserción de los musulmanes hispanos en el Magreb (1516-1541). In: MILLÁN MARTÍNEZ, J. (Org.). Carlos Vy la quiebra del bumanismo político en Europa (1529-1558). Madri: Sociedad Estatal para la Conmemoración de los Centenarios de Felipe II y Carlos V, 2001. p. 469-485.

FIGUEIREDO, Luciano R. de A. Furores sertanejos na América Portuguesa: rebelião e cultura política no sertão do rio São Francisco, Minas Gerais (1736). Oceanos, n. 40, p. 128-144. out/dez. 1999.

FIGUEROA, Padre-Mestre Francisco de. Tratado breve del dulcissimo nombre de Maria. Lima: Iosef de Contreras, 1642. <http://books.google.com.br/books/download/Tratado_breve_del_ dulcissimo_nombre_de_M.pdf?>

FRANCH, Joan Feliu. Significados alquímicos de la iconografía Cristiana. Millars: Espai i bistoria, Valencia, n. 28, 2005, p. 115-134.

GALERIA DE ARTE DO SESI (São Paulo, SP). O Universo mágico do barroco brasileiro: catálogo. São Paulo, 1998.

GANDRA, Manuel J. Joaquim de Fiore, Joaquimismo e Esperança Sebástica. Lisboa: Fundação Lusíada, 1999.

GARCÍA, Francisco. Vida, virtudes, y milagros de S. Ignacio de Loyola fundador de la Compañia de Jesus. Madri: Don Gregorio Hermosilla, 1722. Disponível em: <http://books. google.es/books?id=Q8_p4zm6rxUC\&source=gbs_navlinks_s $>$.

GASPAR, Tarcísio de Souza. Palavras no chão: murmurações e vozes em Minas Gerais no século XVIII. Dissertação (Mestrado em História) - Instituto de Ciências Humanas e Filosofia da Universidade Federal Fluminense, Niterói, 2008.

GERAU, Francesc. Declamaciones sacras, politicas y morales sobre todos los evangelios de la Quaresma: con los assuntos ocurrentes de limosna, San Mathias, Santo Thomas, Encarnacion, Dolores, Soledad, Patrocinio de la Virgen Santissima y del Mandato. Madri: Francisco Laso, 1709. Disponível em: <http://books.google.es/books? id=CLCHr11YzOoC\&printsec=frontcover\&sourc e=gbs_ge_summary_r\&cad $=0 \# v=$ onepage $\& q \& f=$ false $>$. 
GERMANO, Giovanni. Li trionfi della Chiesa e la sperata universale monarchia. Napoli: Castaldi, 1674. Disponível em: <http://books.google.es/books?id=LIZ1G4QZAGgC\&dq=\%22giov anni+germano\%22\&source=gbs_navlinks_s $>$.

GOMES, Plínio Freire. Um Herege Vai ao Paraíso. Cosmologia de um ex-colono condenado pela Inquisição (1680-1744). São Paulo: Companhia das Letras, 1997.

GONÇALVES, Flávio. A "Árvore de Jessé” na arte portuguesa. Revista da Faculdade de Letras, Universidade Portucalensis, II Série, Porto, v. 3, p. 213-238, 1986. Disponível em: <http://ler. letras.up.pt/uploads/ficheiros/2047.pdf>.

GOUVÊA, Manuel de. Sermoens varios, e discursos predicaveis, politicos, panegyricos e moraes. Lisboa: Antonio Pedrozo Galram, 1723. Disponível em: <http://books.google.pt/ books?id=HMxVy1XDJbQC\&hl=pt-BR\&source=gbs_navlinks_s $>$.

GRABAR, André. Les voies de la création en iconographie chrétienne. Paris: Flammarion, 1979. Las vías de la creación en la iconografia cristiana. Madri: Alizanza, 1985.

HALBRONN, Jacques. Misères de l'histoire de l'Astrologie [Gaston Bachelard et les 'Véritables Connoissances des Influences Célestes et sublunaires' de R. Decartes (sic)]. Disponível em: $<$ http://cura.free.fr/xv/14halbr6.html>.

HARAN, Alexandre. Le lys et le globe: messianisme dynastique et rêve impérial en France à l'aube des temps modernes. Paris: Champ Vallon, 2000

HASKELL, Francis. Mecenas e pintores: arte e sociedade na Itália barroca. São Paulo: Edusp, 1997.

HAY, Beatriz Mariscal. Del contexto histórico al contexto literario: Observaciones sobre los «Coloquios Espirituales» de Fernán González de Eslava. In: Perspectivas transatlánticas en los estudios coloniales hispanoamericanos. Madri: Verbum, 2004. p. 93-102. Disponível em $<$ http://www.cervantesvirtual.com/servlet/SirveObras/01476282099173240132268/p0000001. htm>.

HEADLEY, John M. Church, empire and world: the quest for universal Order, 1520-1640. Aldershot: Ashgate, 1997.

HEERS, Jacques. Gênes au XVe. siécle: civilisation méditerranéenne, grand capitalisme, et capitalisme populaire. Paris: Flammarion, 1971.

HEREDIA MORENO, Maria del Carmen. Origen y difusion del águila bicéfala en la platería religiosa española y hispanoamericana. Archivo Español de Arte, Madri, n. 224, p. 183-194, 1996.

JESÚS MARÍA, Padre Frei Juan de. Árbol de la vida, con doze frutos al año en sermones varios de los Misterios, y de los Santos mas clasicos, que celebra nuestra Madre la Iglesia... Zaragoza, 1718.

KOSER, Constantino, O.F.M. La Mariología en la Orden Franciscana. In: El pensamiento franciscano. Madri: Marova, 1972. p. 71-87. Disponível em: <www.franciscanos.org/virgen/ koser2.html>.

LE GOFF, Jacques. La civilisation de l’Occident Médiéval. Paris: Flammarion, 1982.

; SCHMITT, Jean-Claude. Diccionario razonado del Occidente medieval. Madri: Akal, 2003. 
LEMOS, Carlos. Patrimônio: 70 anos em São Paulo. São Paulo: IPHAN, 2008.

LISBOA, João Francisco. Vida do Padre António Vieira. Rio de Janeiro: M. Jackson, 1956.

MACHADO DE CHAVES. Juan. Perfeto confesor y cura de almas...: tomo primero dividido en tres libros. Madri: la viuda de Francisco Martinez, 1647.

MADURO, Carlos Alberto de Seixas. Um sermonário Mariano de Vieira, Maria Rosa Mística. 1998. Dissertação (Mestrado em Literatura Portuguesa) - Faculdade de Filosofia da Universidade Católica de Braga, Braga, 1998.

MAELLA, Frei Salvador. Revelaciones del Santo Profeta Daniel, explicadas de la Ilustre Casa Austriaca.1658.

MAGALHÃES, Leandro Henrique. A tradição messiânica portuguesa e a constituição do Quinto Império". Tuiuti: Ciência e Cultura, Curitiba, n. 41, p. 209-220, jan.- jun. 2009.

MARQUES, João Francisco. A Parenética portuguesa e a Restauração, 1640-1668. Porto: Instituto Nacional de Investigação Científica, 1989.

MARTÍNEZ CUESTA, Ángel (O.A.R.). María en la espiritualidad y apostolado de los Agustinos Recoletos. In: VV. AA. Agustinos recoletos. Historia y espiritualidad. Madri: Avgvstinvs, 2007. p. 479-509. Disponível em: <http://www.agustinosrecoletos.com/documents/viewfile/190>.

MATA, Juan de. Parayso Virginal de discursos predicables en las fiestas de la siempre Virgen Maria madre de Diós, y Señora nue_tra ... Pamplona: Carlos de Labàyen, 1631.

MAUGERI, Padre José Maria (S. J.). Práctica de la devoción a los santissimos... Corazones de Jesús y Maria. Barcelona: Mauro Marti, 1743. Disponível em: <http://books.google.es/books?> .

MEIER, Johannes. "Totus mundus nostra fit habitatio": Jesuiten aus dem deutschen Sprachraum in Portugiesisch- und Spanisch-Amerika (Abhandlungen der Geistes- und Sozialwissenschaftlichen Klasse (AM-GS)). Mainz: Franz Steiner, 2010.

"Totus mundus nostra fit habitatio": Jesuitas del territorio de lengua alemana en la América portuguesa y española. Disponível em: <http://ler.letras.up.pt/uploads/ficheiros/4319.pdf>.

MENDES, Margarida Vieira. Comportamento profético e comportamento retórico em Vieira. Revista Semear, Rio de Janeiro, n. 2. Disponível em <http://www.letras.puc-rio.br/catedra/ revista/2Sem_07.html>.

MENEZES, Francisco Xavier de (conde da Ericeira). Henriqueida: poema heroico, com advertencias preliminares das regras da poesia epica, argumentos e notas. Lisboa Occidental: Antonio Isidoro da Fonseca, 1741. Disponível em: <http://www.archive.org/details/ henriqueidapoema00eric $>$.

MONOD, Paul Kléber. The Power of Kings, Monarchy and Religion in Europe, 1589-1715. New Haven: Yale University Press, 1999.

MUXICA, Antonio. La flor mas propria de la maravilla convertida en la Azucena de Padua. Madri: Imprenta del Convento de Nuestra Señora de la Merced, 1728.

NAVARRO, José Gabriel. Artes Plásticas Equatorianas. México: Fondo de Cultura Económica, 1945. 
OLIVEIRA, Frei José de (O.E.S.A). Sermoens varios que prégou ... Fr. Ioseph de Oliveyra ... Religioso dos Eremitas de Santo Agostinho... Lisboa: Francisco Xavier de Andrade, 1723.

ORR, Bridget. Empire on the English Stage 1660-1714. Cambridge: Cambridge University Press, 2001.

PACHECO, Helder. Portugal, Património Cultural Popular. 1: O ambiente dos homens. Porto: Areal, 1985.

PADGEN, Anthony. Instruments of Empire: Tommaso Campanella and the Universal Monarchy of Spain. In: Spanish Imperialism and the political imagination. New Haven: Yale University Press, 1990.

Lords of All the World: Ideologies of Empire in Spain, Britain and France c.1500-c.1800. New Haven: Yale University Press, 1998.

PANOFSKY, Erwin. Significado das Artes Visuais. 2. ed. São Paulo: Perspectiva, 1979.

PARSONS, Anna Maria; MARTINS, Anna Maria; ALLEN, Fernando. El Espejo Salvaje. Asunción: Fotosintesis, 1992.

PLATH, Oreste. Primacia y estirpe de los metales en Chile. Tradición, Revista Peruana de Cultura, Cuzco, n. 19-20, p. 399-417, jun. 1955- enero 1957.

PÉCORA, Alcir. Teatro do Sacramento: a unidade teológica-retórico-política dos Sermões de Antônio Vieira. São Paulo: Edusp; Campinas: Editora da Unicamp, 1994.

PELOSO, Silvano. Antônio Vieira e o Império Universal: a Clavis Prophetarum e os documentos inquisitoriais. Rio de Janeiro: De Letras, 2007.

PEREIRA, Juan Carlos. Imperio Otomano. Política. Ariel: Barcelona, 2008. p. 499.

Diccionario de Relaciones Internacionales $y$

PINCUS, Steven. Popery, Trade and Universal Monarchy: the ideological context of the outbreak of the Second Anglo-Dutch War. English Historical Review, v. 107, p. 1-30, 1992.

The Making of a Great Power? Universal Monarchy, Political Economy, and the Transformation of English Political Culture. The European Legacy, v. 5, n. 4, p. 531-545, 2000.

To Prevent a Universal Monarchy: English political culture and images of power in seventeenth-century Europe. New Haven: Yale University Press, 2008.

PINTO, Clara Vaz; MONTEIRO, João Pedro. Colchas de Castelo Branco. Lisboa: Museu de Francisco Tavares Proença Júnior, 1993.

POMIAN, Krzysztof. História Cultural, História dos semióforos. In: RIOUX, Jean-Pierre; SIRINELLI, Jean-François (Org.). Para uma bistória cultural. Lisboa: Estampa, 1998. p. 71-95.

PONS, Luis Bernabé. El exilio morisco. Las líneas maestras de una diáspora. Revista de Historia Moderna, n. 27, p. 277-294, 2009. Disponível em: <http://rua.ua.es/dspace/bitstream/10045/ 12710/1/RHM_27_11.pdf>.

PROST, Antoine. Social e cultural indissociavelmente. In: RIOUX, Jean-Pierre; SIRINELLI, JeanFrançois (Org.). Para uma história cultural. Lisboa: Estampa, 1998. p. 123-137. 
QUINTANADUEÑAS, Padre Antonio (S. J.). Nombre Santissimo de Maria: su Excelencia, Significados, Veneracion y Efectos. Sevilha: Francisco de Leyra, 1643.

REDONDO, Augustin; AGUILAR, Christine (Orgs.). La prophétie comme arme de guerre des pouvoirs, XVe-XVIIe siècles. Paris: Presses Sorbonne Nouvelle, 2001.

REIS, Manuel dos. Sermoens do Padre Manoel dos Reys da Companbia de Jesus...; primeira parte, em que se contem muitos sermoens pertencentes ao Advento \& Quaresma com outros adjuntos. Évora: Oficina da Universidade, 1717.

RIBERA, Adolfo Luis; SCHENONE, Héctor. El Arte de la imaginería en el Río de la Plata. Buenos Aires: Facultad de Arquitectura y Urbanismo de la Universidad de Buenos Aires, 1948.

ROMEIRO, Adriana. Um visionário na Corte de D. João V: Revolta e milenarismo nas Minas Gerais. Belo Horizonte: Editora da UFMG, 2001.

SAAVEDRA FAJARDO, Diego. Corona gothica, castellana y austriaca: politicamente ilustrada: parte primera... Madri: Juan Jansonio, 1646.

SARAIVA, António José. "Rusticano", uma fonte joaquimita de Vieira. In: VV. AA. Studia Ibérica. Berna: Francke, 1973. p. 575-579.

SCHMIDT, Peer. La imagen de Felipe II en el Imperio Germano-Romano y en la historiografía alemana y austríaca. Espacio, Tiempo y Forma: Serie IV, Historia Moderna, t. 11, n. 73, p. 39-83, 1998. Disponível em: http://e-spacio.uned.es/fez/eserv.php?pid=bibliuned:ETFSerie4-613910DE98A1-553D-F231-1D0BD3F3441A\&dsID=PDF.

Felipe II y el mundo germánico. In: ALVAR EZQUERRA, Alfredo (Org.) Imágenes bistóricas de Felipe II. Alcalá de Henares: Centro Estudios Cervantinos, 2000.

Spanische Universalmonarchie oder "teutsche Libertet». Das spanische Imperium in der Propaganda des Dreissigjäbrigen Krieges [La monarquía universal española o la libertad alemana. El imperio español en la propaganda de la Guerra de los Treinta Años]. Stuttgart: Franz Steiner, 2001.

SECRET, François. I cabbalisti cristiani del Rinasciment. Milano: Arkeios, 2001.

SEGNERI, Paolo. Mana del alma o Exercicio facil y provechoso para quien desea darse de algun modo à la oracion. Madri: Francisco Laso, 1702. Disponível em: <http://books.google.es/books?i $\mathrm{d}=\mathrm{Vn} 910982 \mathrm{n} 2 \mathrm{sC} \& \mathrm{dq}=\mathrm{Mana}+\mathrm{del}+\mathrm{alma}+\mathrm{o}+$ Exercicio + facil $+\mathrm{y}+$ provechoso + para + quien $+\mathrm{desea} \&$ source=gbs_navlinks_s $>$.

SEPP, Padre António (S. J.). Relación de viaje a las misiones jesuíticas, 1. Buenos Aires: Eudeba, 1971.

SERAFIM, João Carlos. Eremitismo, Profecia e Poder: o caso do Libellus do "pseudo-eremita" Telésforo de Cosenza. Via spiritus, Porto, n. 9, p. 61-82, 2002. Disponível em: <http://ler.letras. up.pt/uploads/ficheiros/3477.pdf>.

SIMÓN DIAZ, José. Fiesta y literatura en el Colegio Imperial de Madrid. Dicenda, Cuadenos de Filología Hispánica, Madri, n. 6, p. 525-537, 1987.

SMITH, Robert C.The Portuguese Woodcarved Retable - 1600-1750. Belas Artes, Lisboa, 1950.

Annals of Museu Paulista. v. 18. n.2. July.-Dec. 2010. 
Atalba em Portugal. Lisboa, Livros Horizonte, 1962.

SOUZA, Laura de Mello e. O Sol e a Sombra. Política e administração na América Portuguesa do século XVIII. São Paulo: Companhia das Letras, 2006.

SUBIAS GALTER, Juan. El arte popular en España. Barcelona: Seix Barral, 1948.

TAPIÉ, Victor. Barroco e Classicismo, 2. Lisboa: Presença; São Paulo: Martins Fontes, 1974.

TAVARES, Pedro Vilas Boas. Paraísos perdidos, paraísos proibidos: o Novo Mundo na Inquisição. Prefigurações emancipalistas da monarquia brasileira. Península. Revista de Estudos Ibéricos, Porto, n. 2, p. 377-399, 2005. Disponível em <http://ler.letras.up.pt/uploads/ficheiros/2972. pdf $>$.

TIRAPELI, Percival (Org.). Arte Sacra Colonial: Barroco Memória Viva. São Paulo: Unesp;Imprensa Oficial do Estado de São Paulo, 2001.

TRINDADE, Jaelson Bitran. A talha da época de Pedro II de Portugal: porta do céu, para a conversão universal. In: COLÓQUIO LUSO-BRASILEIRO DE HISTÓRIA DA ARTE, 6., 2003, Rio de Janeiro. Anais, 1... Rio de Janeiro: CBHA, PUC-RJ, UERJ,UFRJ, 2004. p. 311-330,

Vieira, o Império e a Arte: emblemática e ornamentação barroca. In: ARANDA, Ana Maria (org.). Barroco Iberoamericano: territorio, arte, espacio y sociedad, 1. Sevilla: Ediciones Giralda/Universidad Pablo de Olavide, 2001, v. 1, p. 242-258. Disponível em <http://www.upo. es/depa/webdhuma/areas/arte/actas/3cibi/documentos/019f.pdf>.

VIEIRA, Frei Francisco (O.S.A.). Lisboa: 1708. Disponível em: $<$ http://books.google.pt/books?id= GYbgKbEkqV8C\&dq=s\%C3\%A30+jo\%C3\%A3o+novo\&source=gbs_navlinks_s $>$.

VIEIRA, Padre Antônio. Cartas. Sel. de Novais Teixeira. Rio de Janeiro: Jackson, 1949.

Defesa perante o Tribunal do Santo Ofício, 2. Salvador (Brasil): Progresso, 1957.

Sermão I - Rosa Mística. In: Sermões Escolbidos, 2. São Paulo: Edameris, 1965a. Disponível em <http://www.cce.ufsc.br/ nupill/literatura/sermo.html>.

Sermão V - Maria Rosa Mística. In: Sermões Escolbidos, 2. São Paulo: Edameris,

1965b. Acesso em meio eletrônico: http://www.cce.ufsc.br/ nupill/literatura/sermv.html

Sermão VIII - Com o Santíssimo Sacramento Exposto. In: Sermões Escolbidos, 2. São Paulo: Edameris, 1965c. Disponível em <http://www.cce.ufsc.br/ nupill/literatura/sermviii. html>.

Cartas do Brasil. São Paulo: Hedra, 2003.

VILLALTA, Luiz Carlos. Reformismo ilustrado, censura e práticas de leitura: usos do livro na América portuguesa, 1999. Tese (Doutoramento em História) - Faculdade de Filosofia, Letras e Ciências Humanas da Universidade de São Paulo, São Paulo, 1999. Disponível em: <http://www. caminhosdoromance.iel.unicamp.br/estudos/teses/pdfs/Villalta99.pdf>.

O Encoberto da Vila do Príncipe (1744-1756): milenarismo-messianismo e ensaio de revolta contra brancos em Minas Gerais. Fênix, Revista de História e Estudos Culturais, v. 4, n. 4, out.dez. 2007. 
WEISMANN, Elizabeth Wilder. Mexico in sculpture, 1521-1821. Cambridge: Harvard University Press, 1950.

WIKIPEDIA. Escuela cuzqueña de pintura. Disponível em: http://es.wikipedia.org/wiki/Escuela_ cuzque\%C3\%B1a_de_pintura.

YEPES, Diego de (Obispo de Tarazona). Discursos de varia historia: que tratan de las obras de Misericordia y otras materias morales: con exemplos y sentencias de santos y gravissimos autores. Toledo: Pedro Rodriguez, 1592. Disponível em: <http://books.google.es/books?id=mpCRUIwRV $\mathrm{s} 8 \mathrm{C} \&$ printsec $=$ frontcover\&source $=$ gbs_ge_summary_r\&cad $=0 \# \mathrm{v}=$ onepage $\& q \& \mathrm{f}=\mathrm{false}>$.

Artigo apresentado em 6/2010. Aprovado em 12/2010. 